WHY DOES EDUCATION INCREASE VOTING?

EVIDENCE FROM BOSTON'S CHARTER SCHOOLS

Sarah Cohodes

James J. Feigenbaum

WORKING PAPER 29308 
NBER WORKING PAPER SERIES

\title{
WHY DOES EDUCATION INCREASE VOTING? EVIDENCE FROM BOSTON'S CHARTER SCHOOLS
}

\author{
Sarah Cohodes \\ James J. Feigenbaum \\ Working Paper 29308 \\ http://www.nber.org/papers/w29308 \\ NATIONAL BUREAU OF ECONOMIC RESEARCH \\ 1050 Massachusetts Avenue \\ Cambridge, MA 02138 \\ September 2021, Revised March 2023
}

We are grateful to Carrie Conaway, Matthew Deninger, Elana McDermott, Alison Bagg, Pierre Lucien, and the staff of the Massachusetts Department of Elementary and Secondary Education and the Boston area charter schools for facilitating the data access which made this project possible. We thank Alex Eble, Don Green, Jeff Henig, Matt Kraft, Celia Paris, Corey Savage, Elizabeth Setren, Kirsten Slungaard Mumma, and conference and seminar participants at the Association for Education Finance and Policy Conference, the Association for Public Policy Analysis and Management Conference, the Centre for Economic Policy Research Education Economics Workshop, the Columbia Women's Microeconomics Lunch, the NYU IES-PIRT Seminar, the Society of Labor Economists Meeting (SOLE), the University of Michigan Ford School, and the University of California \{ Riverside for very helpful comments. Special thanks also go to Jacob Brown, Ryan Enos, Todd Rodgers, and to the Harvard Multidisciplinary Program in Inequality and Social Policy. Cameron Arnzen, Selena Cardona, Grant Goehring, Elizabeth Huffaker, Erin Huffer, and Katharine Parham provided excellent research assistance. This study was deemed exempt from human subjects review by the Teachers College Institutional Review Board. The views expressed herein are those of the authors and do not necessarily reflect the views of the National Bureau of Economic Research.

At least one co-author has disclosed additional relationships of potential relevance for this research. Further information is available online at http://www.nber.org/papers/w29308

NBER working papers are circulated for discussion and comment purposes. They have not been peer-reviewed or been subject to the review by the NBER Board of Directors that accompanies official NBER publications.

(C) 2021 by Sarah Cohodes and James J. Feigenbaum. All rights reserved. Short sections of text, not to exceed two paragraphs, may be quoted without explicit permission provided that full credit, including $(\mathcal{C}$ notice, is given to the source. 
Why Does Education Increase Voting? Evidence from Boston's Charter Schools

Sarah Cohodes and James J. Feigenbaum

NBER Working Paper No. 29308

September 2021, Revised March 2023

JEL No. D72,H75,I21

\begin{abstract}
In the United States, people with more education vote more. But, we know little about why education increases political participation or whether higher-quality education increases civic participation. We study applicants to Boston charter schools, using school lotteries to estimate charter attendance impacts for academic and voting outcomes. First, we confirm large academic gains for students in the sample of charter schools and cohorts investigated here. Second, we find that charter attendance boosts voter participation. Voting in the first presidential election after a student turns 18 increased substantially, by six percentage points from a base of 36 percent. The voting effect is driven entirely by girls and there is no increase in voter registration. Rich data and the differential effects by gender enable us to explore multiple potential channels for the voting impact. We find evidence that charter schools increase voting by increasing students' noncognitive skills.
\end{abstract}

Sarah Cohodes

Teachers College

Columbia University

525 West 120th Street

New York, NY 10027

and NBER

cohodes@tc.columbia.edu

James J. Feigenbaum

Department of Economics

Boston University

270 Bay State Road

Boston, MA 02215

and NBER

jamesf@bu.edu

An online appendix is available at http://www.nber.org/data-appendix/w29308 


\section{Introduction}

People with more years of education vote at higher rates: over the last thirty years, voter turnout has been at least ten percentage points higher for college graduates than high school graduates and even higher when compared to those who do not finish high school (McDonald 2019, based on the CPS). This is one factor contributing to a political and policy process that responds to the preferences of and benefits elites (Gilens and Page, 2014). Some evidence exploiting exogenous variation in years of schooling shows that the relationship between years of education and civic participation is causal (Dee, 2004; Milligan et al., 2004; Sondheimer and Green, 2010; Oreopoulos and Salvanes, 2011; Dinesen et al., 2016); however, other studies find no change in voting among those with more education, implying that the association between voting behavior and education may be a proxy for other factors contributing to both education and civic participation (Berinsky and Lenz, 2011). ${ }^{1}$ But, even in the cases where a causal link between education and voting is established, we know little about why education increases voting.

To understand both if and how education influences civic participation, we examine the case of Boston charter schools. Attendance at Boston charter schools boosted pass rates on high school exit exams, test scores, and college attendance (Angrist et al., 2016), so we have a clear case of educational improvement. However, these academic gains may not translate into increased civic participation if education is a correlate of voting, rather than a causal factor behind it. Additionally, charter schools are a particularly interesting setting to understand voter participation. Charters are often criticized for shifting both students and funding away from traditional public school systems - an institutional feature that could lead students and their families to consider themselves separate from their communities and potentially depress voting rates.

In this paper, we study applicants to Boston charter schools from the projected high school classes of 2006 to 2017, generating causal estimates based on the charter school lotteries. We confirm the academic benefits of charter attendance persist in our larger sample, which includes more schools and more years of lottery data than Angrist et al. (2016). We then match student data to voter files from Massachusetts and nearby states. In the voter files, we observe party registration and election turnout in elections from 2008 to 2018. Looking at the first presidential election after students turned 18, we see that charter school attendance substantially increased voter turnout in those elections. Specifically, voter participation increased by six percentage points off a base of 35 percent, a 17 percent increase in voting participation.

\footnotetext{
${ }^{1}$ We focus on evidence from the United States that has a causal identification strategy that goes beyond matching. As Sondheimer and Green (2010) write, "From the early work of Merriman and Gosnell (1924) to today, literally thousands of cross-sectional surveys have indicated that turnout rates climb with years of formal schooling." Evidence from Europe with similarly rigorous methods generally finds less of a link between education and voting. Milligan et al. (2004), in contrast to their findings in the US, do not see a robust link between education and voting in the UK. Comparing twins, Dinesen et al. (2016) find effects of education in Denmark but not in Sweden. Focusing on compulsory school laws, Siedler (2010) and Pelkonen (2012) find, respectively, that German and Norwegian education reforms that increased years of schooling did not increase voting rates. Lindgren et al. (2019) also find that a Swedish education reform which increased years of education did not boost overall voting rates, but it did increase participation for students from families in the lowest quartile of socioeconomic status. A related literature explores the connection between education and civic participation in the developing world (Wantchekon et al., 2015; Friedman et al., 2016; Croke et al., 2016; Larreguy and Marshall, 2017) and for the most part, finds that education increases voting and related political engagement. But Croke et al. (2016) show that in the context of an authoritarian regime, education actually decreases voting as a form of protest, or "deliberate disengagement."
} 
However, our overall results obscure a striking difference by gender: young women who attended charter schools are 11 points more likely to vote in their first possible presidential election, while we see no effect on young men. The differences by gender are large and statistically significant. In recent decades, a gender gap in political participation has emerged, with women voting at higher rates than men (Cascio and Shenhav, 2020; Burns et al., 2018). This gap may be driven by education, as Cascio and Shenhav (2020)'s analysis using cross-cohort and cross-state variation suggests, and our findings add causal evidence of the connection between education and the voting gender gap. Our estimated gender gap also allows us to illuminate the mechanisms connecting education to voting.

We find that the effect of charters on civic participation operates exclusively in presidential general elections. While charter attendance boosts the likelihood that young people subsequently show up and vote in presidential elections, we see that voter turnout in non-presidential general elections and primary elections is low for both young women and men and is not affected by charter attendance. We also present evidence that our effects operate via the turnout margin, not the registration margin. That is, charters do not change who appears on the voter rolls - and thus in the voter files - just whether or not registered voters actually vote.

Rich administrative data sources enable an exploration of mechanisms. We observe that because charter attendance induces similar college enrollment gains in both young women and young men but only boosts voting for young women, the link between education and voting does not appear to be a simple story of more education inducing more voting. We consider five theoretical explanations behind the link between education and voting: cognitive skills, civic skills, noncognitive skills, social networks, and policy feedback. The large differences by gender we find in the effects of charters motivate, in part, how we test mechanisms: if we do not see differential charter effects by gender on a mechanism, that makes it less likely to be a mechanism driving our voting results. ${ }^{2}$ We find evidence consistent with the idea that noncognitive skills may affect voting. Charters increase our proxies for noncognitive skills - attendance rates and SAT taking - for young women but not young men, which is consistent with noncognitive skills driving the voting gains. We cannot fully exclude alternative explanations, but the evidence for cognitive or civics skills as well as the policy feedback channel is weak. Evidence that social networks play a role is mixed. The exploration of mechanisms is relevant not just to the charter school context, but also to the question of why education increases voting more generally.

This paper contributes to the literature in five main ways. First, it adds rigorous, lottery-based evidence on the impacts of attending schools that boost college enrollment to the literature that links education and civic participation. Much of this literature is based on compulsory schooling laws and interventions that are now decades old (Dee, 2004; Milligan et al., 2004; Oreopoulos and Salvanes, 2011). Our work is closest in spirit to Sondheimer and Green (2010), who show that exposure to three classic

\footnotetext{
${ }^{2}$ In logic reminiscent of a Kitagawa-Oaxaca-Blinder decomposition, Burns et al. (2018) frames the gender gap in political participation as a question of levels or effects. Political participation could be different across women and men because of level differences in so-called political resources (the attributes that drive voting including education, income, political interest and others) or because the effects of some attribute of voting differs for men and women. Burns et al. (2002) conclude that the gender gap in political participation has been driven by differences in levels rather than effects. This motivates the contours of our analysis of mechanisms.
} 
and well-studied educational interventions that increase high school graduation also increase voting. ${ }^{3}$ However, the total sample size across all three sites is only 1,636, less than 20 percent of our sample size.

Second, we add to the limited evidence on charter schools and voting. Charter schools are an interesting setting to examine civic participation, since they may push students both towards civic participation (through education effects) or away (since charters can be considered exclusionary). Gill et al. (2020) is the only other study which uses lotteries to estimate impacts on voting, and it finds that charter attendance increases voter participation by 12 percentage points. Since it studies a single, civics-focused schoolDemocracy Prep - which also boosts test scores (Corcoran and Cordes, 2015), it is difficult to know if the civics-focused curriculum is a necessary component of the charter effects on voting. McEachin et al. (2020) also study charters, using matching and regression techniques to show that North Carolina charters boost voter registration and turnout, alongside gains in attendance and reductions in suspensions and criminal activity. While the estimation techniques in McEachin et al. (2020) reduce omitted variable bias, they do not have a natural experiment. Fortson et al. (2015) show that regression and matching techniques can come close to replicating charter school lottery test score impacts, but do not match up perfectly. They also highlight that pretreatment test scores are key to these comparisons. While McEachin et al. (2020) have pretreatment data on test scores, it is unclear what the appropriate pretreatment variable would be for voting or other non-academic outcomes, which may undermine matching techniques in this context. ${ }^{4}$ When it comes to showing charter school impacts on voting, our setting goes beyond a single school, has clear identification through the lotteries, and offers rich data and institutional knowledge to explore mechanisms.

Third, our evidence on voting contributes to a small literature on the impacts of charter schools on a broader set of nonacademic outcomes. This literature includes the previously discussed Gill et al. (2020), as well as Hastings et al. (2012), Wong et al. (2014) and Dobbie and Fryer (2015). These are the only other lottery-based studies that go beyond academics to find beneficial impacts of charter attendance on absences, teen pregnancy, criminal activity, and risky behaviors. Imberman (2011), Spees (2019), and McEachin et al. (2020) also show charters improve attendance and disciplinary outcomes with observational evidence using regression and matching methods. Together, this growing literature on voting, absences, and risky behaviors shows that the gains demonstrated in a subset of charter schools are not restricted to test scores. Outside of charter schools, Jackson et al. (2020) shows that schools have separable impacts on test scores and socio-emotional development, and that longer-term outcomes like college enrollment are better explained by both, implying that successful schools impact young people beyond academics.

Fourth, we bring evidence to bear on how education increases civic participation. While there are many potential theories as to why education increases voting, prior work that shows a causal connection

\footnotetext{
${ }^{3}$ Sondheimer and Green (2010) study the Perry Preschool Project (a randomized controlled trial of access to a demonstration preschool), Project STAR (a randomized controlled trial of class size reduction in Tennessee), and I Have A Dream (a scholarship and support program for one cohort of students who are compared to neighboring cohorts). All three interventions increase voting alongside educational benefits.

${ }^{4}$ With respect to estimating charter impacts in Texas using observational data, Dobbie and Fryer (2020) point out that Chetty et al. (2014) show that prior test scores do not fully account for determinants of earnings, whereas family income and background do. If voting behavior also has unobserved antecedents beyond test scores, matching techniques based on pretreatment test scores will be biased - a problem eliminated by using lottery-based estimates of charter impacts.
} 
between education and voting typically documents the link, rather than explaining the mechanisms behind it, or comparing several mechanisms against each other. ${ }^{5}$ In our context, we set up tests of the five major theoretical explanations of why education may increase voting: cognitive skills, civic skills, noncognitive skills, social networks, and policy feedback. Here, we show that in the cases where education does increase civic participation it is likely due to gains in noncognitive skills as well as charter schools' politicization of families, which we observe through greater rates of parent voting after the charter school lottery. Understanding these mechanisms helps to clarify the settings under which it makes sense that we would see educational impacts on voting, and the cases where we would not. We are the first paper we are aware of which is able to test all five potential channels in a single setting, and one of the few papers that is able to explore mechanisms in the context of well-identified impact estimates.

Finally, we contribute to the understanding of the gender gap in voting behavior. In recent decades, women have outvoted men (Burns et al., 2018; Cascio and Shenhav, 2020). The gap is about 4 to 5 percentage points in favor of women in presidential elections. The typical explanations are that women's educational gains over the past half century (Goldin et al., 2006; Goldin and Katz, 2010), alongside changes in gender roles, women's economic power, and political role models, have contributed to women overtaking men when it comes to voting (Burns et al., 2018). Cascio and Shenhav (2020) show that gains in high school graduation are closely tied to gains in voter participation for women, but not for men. We show that women's educational gains certainly contribute to the gender voting gap, but that the crucial resources imbued by education may well be noncognitive skills and not greater knowledge or income, as previously theorized.

The paper proceeds as follows. We next describe the theoretical connections between education and voting in Section 2. In Section 3, we describe the setting and related literature on charter schools, data, and sample. Section 4 describes the methods. Sections 5 and 6 include results for academic outcomes and voting, respectively. We explore the mechanisms behind the increases in voter participation in Section 7 and conclude in Section 8.

\section{Education and civic participation}

Americans with more education vote more (McDonald, 2019). This could be due to correlation not causation, as people who obtain more education come from wealthier backgrounds, earn more, and have different life experiences - any of which could be the driving force behind observed differences in voting behavior between those with more and less education. However, some plausibly exogenous increases in education in the United States led to greater voting rates (Dee, 2004; Milligan et al., 2004; Sondheimer and Green, 2010; Oreopoulos and Salvanes, 2011), implying a causal relationship at least in some scenarios. ${ }^{6}$ Understanding the mechanisms through which education plausibly affects voting, and

\footnotetext{
${ }^{5}$ This is true of both the older literature exploiting compulsory schooling laws and the two recent papers linking charter school attendance and voting - Gill et al. (2020) and McEachin et al. (2020). Hillygus (2005), Nie and Hillygus (2008), Holbein et al. (2020) and Holbein and Hillygus (2020) are notable exceptions which explore multiple potential mechanisms. However, these studies mostly rely on regression adjustment and matching techniques, and do not have a natural experiment. Holbein (2017) is able to test multiple mechanisms in the context of an RCT, but the intervention studied there - FastTrack - focuses on specifically on psycho-social skills, rather than education more generally.

${ }^{6}$ As mentioned in Section 1, Berinsky and Lenz (2011) find no effect of education on civic participation.
} 
determining if any such mechanisms are moved by educational experiences, can clarify our understanding of whether education indeed causes civic participation or if they are merely correlated with each other.

Why might education increase voting? Theoretical explanations are typically grounded in a "resource model" of voting, which posits that voters need resources (e.g., time, money, skills) in order to overcome barriers to voting and that education can endow those resources (Brady et al., 1995). When it comes to the specific resource endowed by education, we consider - and later test - four of the most common possibilities (Persson, 2015): cognitive skill, civic skill, noncognitive skill, and social networks. We also consider a fifth possibility in parallel to ones inspired by the resource model: the "policy feedback" channel where engagement with specific policies in turn engages participants in the political process. These are the theoretical channels we believe have the greatest likelihood of being changed by charter school attendance.

\subsection{Five reasons why charter schooling might increase voting}

The most prominent theoretical channel behind the relationship between education and voting is that education develops cognitive skills, and that those with greater skills are more likely to vote as they have the language skills necessary to understand and form opinions about political topics and to navigate the political participation process (Wolfinger and Rosenstone, 1980; Verba et al., 1995; Nie et al., 1996). ${ }^{7}$ The basis of this theory is the "resource model": the idea that voting is costly and citizens need resources to overcome barriers to voting. Increasing cognitive skill gives people resources to overcome those barriers (Verba et al., 1995). Nie et al. (1996) identify verbal skills as particularly important, and Hillygus (2005) and Nie and Hillygus (2008) show that among college graduates, verbal SAT scores are more predictive of voter turnout than math. As the charter schools we study here have demonstrated gains in achievement tests, including measures of verbal ability, there is potential for a cognitive skills explanation for the voting effects.

A related human capital explanation is that education builds civic participation-specific human capital in students, typically called civic skills - through exposure to civics education and related content - and that knowledge of the political system increases participation. One rationale for public provision of education is to ensure an informed citizenry; ${ }^{8}$ most states make this explicit by requiring some form of civics education (Hansen et al., 2018). However, there is little rigorous evidence that exposure to civics curriculum leads to increased voting. Green et al. (2011) randomize additional civics curriculum across 59 high school classes and find that students exposed to the curriculum do have greater knowledge of the content, but the authors do not directly test voting behavior. Non-experimental evidence is mixed. Buckley and Schneider (2009) explore the impacts of D.C. charter schools on "building citizenship" using survey data and matching techniques, finding that charter students tend to have greater civic skills than their public school peers. Weinschenk and Dawes (2021) use high school transcript data linked to voting records and family fixed ef-

\footnotetext{
${ }^{7}$ Developing cognitive skills might lead a student to the rational choice model of voting, which posits than no rational individual would vote, since the likelihood of changing the outcome of an election is minuscule (Downs, 1957).

${ }^{8}$ John Adams wrote this idea into the Massachusetts Constitution: "Wisdom, and knowledge, as well as virtue, diffused generally among the body of the people, being necessary for the preservation of their rights and liberties; and as these depend on spreading the opportunities and advantages of education in the various parts of the country, and among the different orders of the people, it shall be the duty of legislatures and magistrates, in all future periods of this commonwealth, to cherish the interests of literature and the sciences..." Similar reasoning is part of most state constitutions in the United States (Rebell, 2018).
} 
fects to show that those exposed to more civics education do not have greater adult turnout. Hillygus (2005) and Nie and Hillygus (2008) do find that college graduates with more social studies credits vote more. Recent reviews of the non-experimental literature come to different conclusions. Manning and Edwards (2014) find few connections between civic education and voter participation, but Campbell (2019) is more sanguine. In both cases, the authors acknowledge that there is little rigorously identified evidence on civic skills, making it difficult to draw a final conclusion. Charter schools in our sample may expose students to more civics curricula in the form of Advanced Placement courses that focus on civics-related topics: AP United States History or AP Government. Furthermore, some of the charters in our sample have explicit civic or communitarian missions - variation we can exploit in our analysis of mechanisms. However, when comparing charter schools to traditional public schools across the nation there do not seem to be large differences. The National Assessment of Educational Progress (NAEP) includes a civics component. In 2018, 8th grade students in public schools scored 152 on the civics exam (out of 300) and charter school students scored 156. In the survey component of the NAEP, 52 percent of traditional public school students reported a class with a main focus on civics or U.S. history in 8th grade, compared to 47 percent of charter school students. ${ }^{9}$

Education can also increase so called "noncognitive" skills (Kautz et al., 2014; Jackson et al., 2020). These socio-emotional or "soft" skills include self-regulation, persistence, and grit. Interventions that increase noncognitive skills increase voting (Holbein, 2017; Holbein and Hillygus, 2020) and "grit" is correlated with voting, even controlling for test scores and other characteristics (Holbein et al., 2020). Holbein and Hillygus (2020) argue that this noncognitive channel in particular, and the development of "follow-through" are more critical to helping citizens surmount barriers to voting than academic skills or knowledge of government systems. They note that voting is a multi-step process (i.e., registration, finding one's polling place, researching candidates, and showing up on time), and that, beyond some basic level of reading knowledge and knowledge of the voting process, follow-through is a much more important skill than knowledge when it comes to voting. ${ }^{10}$ This channel might be particularly relevant in the United States, where the franchise is not universal: noncognitive skills are necessary to navigate the voting process when the voting process is intentionally made difficult via long waits at polling places and ID requirements for voter registration and voting. Gallego (2010) and Chevalier and Doyle (2012) find that institutional barriers in the voting process explain the education-voting gradient in the United States and its absence in Europe, which does not have the same level of voter suppression. Indeed, simple interventions, like "pre-registering" young people, can increase voting rates (Holbein and Hillygus, 2016), indicating that the barriers built into the American voting process are meaningful.

No excuses charter schools, with their emphasis on behavior and an academic program that requires follow-through may very well develop these noncognitive skills to a greater extent than their traditional public school counterparts. Though noncognitive skills are difficult to measure, some observed behaviors

\footnotetext{
${ }^{9}$ For NAEP results by school type, see https://www.nationsreportcard.gov/dashboards/schools_dashboard.aspx

${ }^{10} \mathrm{~A}$ similar argument can be made for college enrollment: Academic preparation is important, but going to college also involves a series of barriers (application, navigating financial aid, registration, etc.) To successfully enroll, students need both the cognitive preparation and the ability to persist through such systems. Interventions that specifically target these noncognitive skills increase college enrollment (Kautz and Zanoni, 2014).
} 
that could correlate such as attendance rates - are increased by charter attendance. Interestingly, in some of the same Boston charter schools studied here, West et al. (2016) find that charter school enrollment actually decreases self-reported measures of conscientiousness, self-control, and grit. However, West et al. (2016) attribute these effects to "reference bias," that is, charter schools resetting the norms of what concepts like conscientiousness and grit mean to their students.

Education may introduce students to new social networks and new social norms; in particular, attending a residential college may introduce students to new communities which may be more central to the political process. In addition to cognitive skill as a pathway to civic participation, Nie et al. (1996) argue that education also provides a "positional pathway" by moving people to more "politically important" social networks. Abrams et al. (2011) show a strong association between the voting rates of informal social networks (friends, family, and colleagues) and individuals' voting. Campbell (2013) argues that a focus on individual factors has left the contribution of social networks to political participation understudied. Recently, Chyn and Haggag (2019) show that young people who moved neighborhoods as children due to public housing demolitions are more likely to vote as adults. They believe part of this is due to increased high school graduation rates, but speculate that there is additional scope for social norms in the new neighborhood to shape voting behavior (though they do not have the data to address this). Angrist et al. (2016) show that Boston charters boost college enrollment, especially at four-year campuses, which draws students into new communities. If these new peer networks and communities are more likely to have a norm of civic participation and to be more central to politically important social networks, education may increase voting by fostering these connections.

Education, of course, is government policy, and charter schools represent a deviation from the typical way government has provided education. As such, education, and charter schools in particular, are subject to a concept long held in political science, wherein "new policies create new politics" (Schattschneider et al., 1935). Formalized into policy feedback theory (Pierson, 1993; Mettler and SoRelle, 2014), this idea holds that when people experience a government policy, in turn it can shape their political views and participation. For example, Michener (2018) shows that the unequal benefits and administrative burdens associated with Medicaid make beneficiaries less likely to vote. In the realm of education, Hastings et al. (2007) find that white and high-income parents of Charlotte-Mecklenburg students who lose a school choice lottery are more likely to vote. In Chicago, Nuamah and Ogorzalek (2021) find that experiencing school closures politicizes Black Americans in affected communities. All of these cases are consistent with the idea that negative interactions with policies are particularly salient for motivating political participation. Charter schools might boost the participation of families that participate; however, the salience of negative policy interactions indicates a more powerful force might be the act of losing a charter school lottery.

\subsection{Summarizing the theoretical explanations}

The actual explanation for the relationship between education and voting is likely a combination of the theories described above. If charter schools produce either greater time in school or more learning during the same time period (as appears to be the case for many urban charter schools), charter schools may induce 
increased civic participation via any of the skill-based theories described. Charter schools - which break the link between neighborhoods and school attendance - may also introduce students and their families to new social networks through new school communities or by increasing college enrollment in new communities.

The relationship between charter schools and the policy feedback hypothesis is more ambiguous. If charter students and their families perceive charter schools to be beneficial government intervention, or if charter school policy debates make it seem that charter schools need support at the ballot box, they may increase their civic participation. Alternatively, charter schools represent increased privatization; exposure to them may induce students and families to be less likely to vote. Cook et al. (2020) find evidence that Ohio school districts with higher shares of charter school enrollment have slightly lower voter turnout, giving credence to the possibility of negative effects. A lower rate of voting could also be due to dissatisfied, charter lottery-losing families heading to the ballot box at a higher rate, similar to district school families in Hastings et al. (2007).

Education may also affect voting by improving employment outcomes and income. Wealthier people are more likely to vote and increasingly dominate the political process in the United States (Schlozman et al., 2018). Increases in family income through cash transfers can increase children's voting (Akee et al., 2020). However, in our context, we do not expect income to be a major channel for voting behavior, as we focus on voting in the first election for which students are eligible. Contemporaneous family income may affect political participation, but the charter school random lottery set up balances this across students. Typically, this election comes near their high school graduation or college enrollment and likely before full-time employment. Thus, we do not focus on income-related explanations.

Prior lottery-based work on charter school attendance and voting shows that one charter network focused specifically on civic participation, Democracy Prep, does increase voting rates (Gill et al., 2020). This provides suggestive evidence on the civics-specific skill channel, but the setting lacks variation to test different mechanisms behind the boost in voting. ${ }^{11}$ North Carolina has an array of charter schools, and McEachin et al. (2020) use regression-adjusted inverse probability weighting to find that charter attendance increases civic participation, alongside decreasing absenteeism and criminal activity. The coincident decrease in absenteeism and criminal activity is suggestive of the noncognitive channel we explore; however, McEachin et al. (2020) do not explore potential mechanisms. Unlike prior work, our rich dataset provides enough context to test many of the theoretical possibilities, which we do in Section 7. Thus, this paper contributes to the limited knowledge on the impacts of charter school attendance on nonacademic outcomes, drawing on evidence from a new context, and contributing to understanding on the connection between education and voting more generally.

\section{Context, data, and descriptive statistics}

To estimate the effects of charter school enrollment on civic participation, we link students with voting behavior - our primary civic outcome in a well-studied charter school context. In this section, we provide

\footnotetext{
${ }^{11}$ Gill et al. (2020) do test whether parents' voting patterns differ after the charter school lottery and find no evidence of such a change.
} 
background information on the Boston charter school sector, document the Massachusetts education data and the voter files used in this analysis, and describe the sample population.

\subsection{Charter schools in Boston}

Charter schools are public schools, funded with public money, but managed by private organizations. In Massachusetts, all charter schools are authorized solely by the state and chartering entities are typically non-profit boards (no for-profit charter schools are permitted in Massachusetts). Charter schools in Massachusetts are also subject to a cap on the percentage of student funding that goes to charter schools, and the City of Boston reached its cap many years ago, which means that the stock of charter schools is established and stable. ${ }^{12}$ As in other states, most charter schools do not participate in collective bargaining and have more flexibility around staffing, scheduling, and curriculum, in exchange for increased accountability under a 5-year "charter" under which a charter school can be closed if it does not meet its agreed upon performance and management standards. The authorizing process in Massachusetts is rigorous, and the state has closed charters schools both for poor performance and poor management. Boston has the highest concentration of charter schools in the state, and most of the charter schools in Boston use policies associated with the "No Excuses" charter school movement: longer school day and year, focus on academic achievement and behavior management, in-school tutoring, frequent teacher feedback, and data-driven instruction (Angrist et al., 2013a; Dobbie and Fryer, 2013).

Previous evidence uses charter school lotteries to show that a year of attendance at a Boston charter school boosts math standardized test scores by about a third of a standard deviation $(\sigma)$ and English/language arts (ELA) by about 0.2 $\sigma$ (Abdulkadiroğlu et al., 2011; Angrist et al., 2013a; Walters, 2018; Cohodes et al., 2021). This finding is persistent in many situations: test score gains exist for students with special needs (Setren, 2021), remain when disciplinary regimes are loosened (Felix, 2020), and are maintained even when charter schools expand to multiple campuses (Cohodes et al., 2021). Additionally, the increases in standardized test scores do not appear to be driven by differential test preparation (Cohodes, 2016). The most recent of these studies (Cohodes et al. 2021, Setren, 2021) include coverage of almost all Boston charter schools, leaving little room for sample selection to be driving the findings. Boston charter attendance also boosts college preparation via AP test-taking and SAT scores, and it increases four-year college enrollment (while decreasing two-year college enrollment), though some students take an additional year to graduate high school (Angrist et al., 2016).

The Boston findings are generally in line with studies of similar charter schools in Chicago, Denver, Los Angeles, New York City, Newark, New Orleans, and KIPP schools, which typically use lotteries to show that attending an urban, No Excuses charter school boosts test scores(Hoxby and Rockoff, 2004; Hoxby et al., 2009; Dobbie and Fryer, 2011, 2013; Angrist et al., 2012; Unterman, 2017; Curto and Fryer,

\footnotetext{
${ }^{12} \mathrm{~A}$ recent change in charter school law raised the funding cap in low-performing school districts (including Boston), which allowed new charters to open. It also restricted expansion to charter schools that could show they were "proven providers" with a track record of success, meaning that many of the charter operators were the same entities already managing schools in the state. The students at these new campuses are too young to reach voting age by the 2016 election and are thus excluded from this analysis. See Cohodes et al. (2021) for details on this expansion and test score impacts.
} 
2014; Hastings et al., 2012; Tuttle et al., 2013; Abdulkadiroğlu et al., 2017; Winters, 2020; Abdulkadiroğlu et al., 2016; Bross et al., 2016). Where it is possible to measure longer-term outcomes, lottery-based evidence also shows that urban charter attendance beyond Boston also increases college enrollment and decreases risky behavior (Dobbie and Fryer, 2015; Davis and Heller, 2019; Wong et al., 2014; Harris and Larsen, 2019). Outside of urban areas, charter school impacts on both test scores and other outcomes are more mixed, see overviews of the broader charter school literature: Chabrier et al. (2016), Epple et al. (2016), Zimmer et al. (2019), and Cohodes and Parham (2021).

\subsection{Data}

School records from the Massachusetts Department of Elementary and Secondary Education (DESE), charter school lottery records, and voting records from the state of Massachusetts are the data sources for this project. DESE provided information on students' names, demographic characteristics, special needs status, and participation in the free/reduced price lunch program from the Student Information Management System (SIMS), test scores in math, ELA, and science from the Massachusetts Comprehensive Assessment System (MCAS) standardized to be mean 0 and standard deviation 1 within subject, grade, and year. records of Advanced Placement taking and scores and SAT taking and scores provided to DESE from the College Board, and college enrollment and degree information from the National Student Clearinghouse (NSC). We follow Angrist et al. (2016), henceforth ACDPW, to create outcomes from these data sources; see that paper for details.

The study sample includes all 12 Boston charter schools with lottery records that enrolled students who were at least 18 by the 2016 general election (see Appendix Table C.2 for details on which schools are included). ${ }^{13}$ Lottery records typically include students names, some additional characteristics like address and date of birth, and lottery information such as the lottery number, waitlist number, offer status, and priority status (sibling, out-of-area, etc.). We match lottery records to student information in the SIMS, primarily matching by name and birth date. Ties are broken using other information in the lottery files (gender, town of residence) and by only matching to students in the appropriate grade range. We use fuzzy matching techniques to connect almost all charter lottery applicants to a SIMS record, with very few differences by lottery status (Online Appendix Table C.5). Siblings, duplicate records, out-of-area applicants and other non-randomized applicants, as well as repeat applicants, are excluded from the lottery-based analysis (see Online Appendix Table C.1 for details on sample exclusions). The remaining lottery applicants are the group subject to random lottery, and we count those who are offered a seat

\footnotetext{
${ }^{13}$ We add five campuses to the sample studied in ACDPW, which included Academy of the Pacific Rim, Boston Collegiate, Boston Preparatory, City on a Hill, Codman Academy, and MATCH High School. To those schools, we add: Boston Green Academy, a second City on a Hill campus, Edward Brooke Roslindale, Excel Academy, MATCH Middle School, and the Mission Hill campus of Roxbury Preparatory Schools (formerly Roxbury Prep). Three closed schools do not participate: Frederick Douglass Charter School (closed 2005), Roxbury Charter High School (closed 2005), and Uphams Corner Charter School (closed 2009). Two charter schools declined to participate: Kennedy Academy for Health Careers (formerly Health Careers Academy) and Helen Davis Leadership Academy (formerly Smith Leadership Academy). A number of additional charter school campuses have opened in Boston, in addition to long-standing elementary schools; however, students for whom we have lottery records at these campuses are too young to have reached voting age by the 2016 election. See Setren (2021) for the most comprehensive coverage of lottery impacts of Boston charter schools.
} 
in the charter school on the date of the lottery as receiving an "initial offer." Students who receive an offer of a charter school seat off the waitlist are counted as having a "waitlist offer." These two mutually exclusive variables serve as instruments in our instrumental variables set-up.

The Massachusetts voter file lists all voters that have been registered in Massachusetts by name, date of birth, their address, their registration date, party registration, and their participation in primary and general elections. We obtained the voter files from 2012, 2015, 2018, and 2020 from commercial vendors who collect this information for political campaign purposes. ${ }^{14}$ To account for out-of-state moves and nearby college attendance, we supplement the Massachusetts voter file with 2018 and 2020 voter files from neighboring states: Connecticut, Maine, New Hampshire, New York, Rhode Island, and Vermont. ${ }^{15}$ These files include the presidential elections of 2008, 2012, 2016, and 2020, and the general elections between these dates. Given the age of our sample, first possible presidential elections are 2008, 2012, and 2016, while the 2020 election contributes to ever voted and share of elections variables.

We match students from the SIMS data to the voter file based on name ${ }^{16}$ and date of birth, and use fuzzy matching techniques to account for minor differences in records. Details on our matching procedures are in Online Appendix 8.

Students are counted as "ever registered" in Massachusetts or a neighboring state if they match to the voter records; we also can determine if students register by a particular relative date, such as by their 19th birthday. We measure voter participation in multiple ways. "Ever voted" outcomes count participation in any election which we further subset to particular election types including: general elections (any November election), presidential elections, off-cycle elections (general elections in non-presidential years), presidential primaries, and other primaries. "Share" outcomes measure the share of elections that a student participated in, out of all the elections they are eligible to participate in, restricted by election type.

Our key voting outcome is participation in the first presidential election after a student turns 18. Since it is possible that charter school attendance influences out-migration from Massachusetts and neighboring states at different rates, a measure of participation in the election closest to students' 18th birthday will be less subject to that risk. It also measures voter participation at the point closest to

\footnotetext{
${ }^{14}$ States vary in the accessibility of voter files. Massachusetts maintains a centralized record but access is limited, see https://www.mass.gov/info-details/mass-general-laws-c51-ss-47c. Commercial vendors collect this information from authorized parties, add their own analytics, and make these files available for purchase for political purposes.

${ }^{15}$ We confirm that presence in the out-of-state voter files is highly correlated with attending college in that state. However, we do not use college attendance location in our links between the student data and the voter file data to avoid biasing our links with a potentially endogenous feature. See Online Appendix Table B.1, which shows a strong alignment between attending college in a nearby state and showing up in the voter file there. However, many of these students are initially registered in Massachusetts and most students who attend college out of state do not end up registering out of state, at least in the time period we observe.

${ }^{16}$ Women changing their name at marriage could affect our ability to match girls to the voter file. However, we note that the median age of marriage for women in Massachusetts is 30.1. The young women in our sample will typically be age 18 to 22 at the date of the first possible presidential election that they can vote in, well prior to the typical age of marriage in Massachusetts. If we do under-match or are unable to include the full voter records of women because of name changes, our estimates will be biased downward, and we will underestimate the magnitude of the any gender gaps we observe that favor women. Indeed, we find the largest voting gender gap for the first possible presidential election and smaller gaps for ever voting, which may be due to name changes as women age.
} 
charter school attendance. Thus, the "First possible presidential" outcome is the primary outcome we track throughout this paper. All voting outcomes are unconditional, with both students not present in the voter file and those who do not vote in an election counted as non-voters.

For a subset of students, the lottery files also contain parent names. We link parents by name to the Massachusetts voter file to assess if charter school attendance (or losing the lottery) politicizes families. In these analyses, we include some more recent charter school lotteries for students who are not yet old enough to vote to increase the sample size of lotteries with parent information. We measure parent voter participation after the charter school lottery and create several measures of civic participation, similar to the ones for students. The parent "ever voted" outcomes count voting in any election after their child's charter school lottery. "First possible presidential" outcomes indicate voting in the presidential election immediately after the lottery. Since we have no birth date for parents, to reduce the number of potential matches in the voter file, we restrict the voter file to Boston residents. We also observe voting prior to the charter school lottery, which we use as a "placebo" outcome to demonstrate lack of selection in our matching techniques. This also means we can compare voting rates before and after the lottery to see changes in voting behavior come from lottery winners or lottery losers, since lottery losers may be motivated to vote by their negative experiences. Since we have no parent information for non-charter applicant families, we cannot compare charter school applicant family voting patterns to other parents in Massachusetts. Section 7.5.1 has details on how our data and estimation strategy differ for the parent voting analysis. Since we only have parent information from the charter lottery files, not the state data, we cannot compare charter applicant parent voting rates to non-charter applicant voting rates.

\subsection{Descriptive statistics}

Students in Boston Public Schools (BPS) and those who apply to charter school lotteries are a broadly similar group, as shown in Table 1 which reports mean demographic characteristics and outcomes for students in BPS (based on cohorts of BPS 9th grade students with projected high school graduation classes that match the charter school sample), students in the Boston charter lottery sample, and lottery winners and losers. About 74 percent of students receive free or reduced price lunch which is consistent across groups, and both BPS and charter applicants are primarily students of color, though charter applicants are more likely to be Black and less likely to be Latinx or Asian. BPS students and charter applicants both have baseline test scores well below the state mean, though charter students are slightly positively selected. Charter applicants and BPS students are similarly likely to receive special education services, but charter applicants are much less likely to be English learners (ELs), though this gap has decreased over time (Setren, 2021). As expected, only a small proportion of the BPS sample, 6.5 percent, which is based on students who attended a BPS school in 9th grade, attended a Boston charter school for at least a year in grades 5-12. This compares to 42 percent of Boston charter school lottery applicants. Just over 50 percent of applicants offered a seat in the lottery ended up attending a Boston charter school, while 24 percent of not-offered students ended up attending a charter school at one point during their K-12 school 
experience. ${ }^{17}$ Consistent with successful randomization in the lotteries, charter lottery winners and losers are broadly similar on all dimensions other than charter school attendance (Online Appendix Table C.3).

\section{Empirical framework}

In this section, we detail the empirical specification that we use to estimate the causal effect of charter attendance on civic outcomes and present the first stage results that validate the lottery winners are more likely to ever attend charter schools and to attain more years of education at charter schools.

\subsection{Methods}

To estimate the effect of Boston charter school attendance on voting outcomes, and, as a benchmark, academic outcomes, we use a two-stage least squares (2SLS) strategy that exploits the natural experiment created by charter school lotteries. Charter attendance may be influenced by many factors we cannot account for, such as family background and motivation, which in turn also influence the choice to vote. We therefore use the randomly-assigned offer of a charter school seat as an instrument for charter attendance. The second stage equation in our 2SLS set-up is:

$$
y_{i}=\sum_{j} \delta_{j} d_{i j}+X_{i}^{\prime} \Gamma+\rho C_{i}+\epsilon_{i}
$$

where $y_{i}$ is an outcome, such as voting in any Massachusetts election, for student $i$. Charter attendance is captured by $C_{i}$, which indicates attendance in one of the Boston charters with lotteries at any point before the outcome is measured if a student applied to that charter school. ${ }^{18}$ The average causal effect of charter school attendance is $\rho$. We include a vector of baseline student characteristics, $X_{i}$, which are race, special education status, English learner status, subsidized lunch status, and a set of year of birth fixed effects, all interacted with gender since we later focus on differences between girls and boys. We also control for lottery fixed effects, in the form of "risk sets." The risk sets, $d_{i j}$, are a set of dummy variables for every combination of charter school applications observed in the data. Including these risk sets takes into account that students who apply to more than one charter lottery are more likely to attend a charter school, limiting comparison to within students who apply to the same set of charter schools. $\epsilon_{i}$ is the error term.

We instrument for charter attendance using randomly assigned charter school offers: the "initial offer" instrument, $Z_{i 1}$, indicates the offer of a charter school seat on the day of the charter school lottery; the "waitlist offer" instrument, $Z_{i 2}$, indicates the offer of a charter school seat off a randomly ordered waitlist which are coded as mutually exclusive dummy variables. In the randomized lottery sample, 30.8 percent of students were offered a seat on the day of the charter school lottery and an additional 29.6 percent of the sample was offered a seat off of the waitlist. A little under 40 percent of the sample was not offered a

\footnotetext{
${ }^{17}$ These estimates do not match exactly to the first stage estimates in Online Appendix Table C.7 since they include attendance at any charter school, not just one with a lottery.

${ }^{18}$ Thus $C_{i}$ will vary across outcomes, with two primary measures. The first is attendance at a lotteried charter in the two years after the charter lottery, for the MCAS test scores two years after potential entrance to a charter. The second is attending a lotteried charter at any point between the charter lottery and high school graduation (or exiting the data).
} 
seat in the lottery. Appendix Table C.2 lists the schools, application years, and the lottery status within each school by year. The analysis sample excludes repeat applicants, siblings, out-of-area applicants, late applicants, and any other applicants that were not subject to randomization through the lottery.

The first stage of the 2SLS set-up follows:

$$
C_{i}=\sum_{j} \mu_{j} d_{i j}+X_{i}^{\prime} \beta+\pi_{1} Z_{i 1}+\pi_{2} Z_{i 2}+\eta_{i}
$$

where $C_{i}$ is a function of the risk sets, the same demographic covariates described above, and the instruments. The effect of a charter offer on attendance is captured by $\pi_{1}$ and $\pi_{2}$, which measure the change in charter attendance induced by the initial and waitlist offer, respectively. Using two instruments increases precision, and the causal effect of charter attendance, $\rho$, is a weighted average of the attendance effects we would have estimated using each instrument separately. We use robust standard errors. Since much of our discussion of mechanisms relies on differences between girls and boys in response to charter attendance, we present our findings for the full sample and separately for girls and boys.

Our lottery-based estimation strategy takes advantage of the random assignment process inherent to charter school lotteries, generating charter impact estimates that are independent of both observed and unobserved student characteristics like ability and interest in school choice. Online Appendix Table C.3 demonstrates that observed student characteristics are similar for offered and non-offered students within risk sets, providing a check on the lottery randomization process. ${ }^{19}$ We also show that matching rates to the SIMS data are very similar for offered and non-offered students (Online Appendix Table C.5) and that follow-up rates for various outcomes do not differ by offer status (Online Appendix Table C.6). Together, these pieces of evidence show that differential presence in the data does not undermine random assignment.

\subsection{First stage}

Before we turn to charter impacts on academic and voting outcomes, we document that the charter school lottery offers do increase charter school attendance. An initial offer increases the likelihood that a student attends a charter during their time in Massachusetts public schools by 46 percentage points, with a waitlist offer increasing charter attendance by 30 percentage points. We show this in Online Appendix Table C.7, which reports coefficients from Equation 2, as well as the attendance rate for students who do not receive any offer. Seven percent of non-offered students do eventually attend a charter school they applied to at some point before they graduate high school or leave the data. This occurs when some students get a seat off the waitlist in subsequent years beyond the year of the lottery that we document, they later receive sibling preference, or they reapply for a later lottery. The non-offered mean is nontrivial, but some students have as many as seven years to gain entrance to a charter, and students that apply in 5th grade have additional opportunities to apply in 6th and 9th grades. The second row of the table

\footnotetext{
${ }^{19}$ We also demonstrate this by predicting voter participation based on voting rates of BPS students with similar demographics and test scores and using those predictions as an outcome in Equation 1. If students with higher likelihoods of voting were more likely to be offered a seat at a charter, using this prediction as an outcome would show positive impacts on voting rates. However, as shown in Online Appendix Table C.4, there are no differences in predicted voting.
} 
reports charter attendance in terms of years of attendance and shows that, on average, non-offered students attend about half a year in a charter and students with an initial or waitlist offer attend an additional 1.6 and 1.0 years respectively. ${ }^{20}$ We also show that girls and boys are equally responsive to charter school offers and are just as likely to enroll if they receive an offer.

Since noncompliance is not incidental in this context, as shown in Column 1 of Online Appendix Table C.7, our preferred way to describe the counterfactual comparison for lottery impacts is the control complier mean (CCM). The CCM is the average value of the outcome for non-offered compliers: students who do not attend a charter when they do not receive an initial or waitlist offer in the first charter school lottery they apply to in our sample. We cannot directly observe the CCM, since charter lottery compliers and nevertakers (those who would not attend a charter even if offered) will be commingled in the non-offered average. Thus, as in Katz et al. (2001), we estimate the CCM as follows, using the methods of Abadie (2002):

$$
y_{i} *\left(1-C_{i}\right)=\sum_{j} \lambda_{j} d_{i j}+X_{i}^{\prime} \alpha+\tau\left(1-C_{i}\right)+\nu_{i}
$$

where $\tau$ is the estimate of the CCM and $\left(1-C_{i}\right)$ is instrumented by $Z_{i 1}$ and $Z_{i 2}$, and risk sets and demographics are accounted for as in Equation 2.

\section{Effects of charter schools on academic outcomes}

While our focus in this paper is on voting, we first benchmark the impact of charter school attendance on academic outcomes against similar estimates of Boston charter school attendance (Abdulkadiroğlu et al. 2011, ACDPW, Cohodes et al. 2021; Setren, 2021). Overall, we show very similar charter impacts in this sample as the literature has found previously. Boston charters continue to show large gains in scores on state exams, AP test-taking and scores, SAT scores, and college enrollment, though charter students continue to take longer to graduate high school.

Figure 1 reports Boston charter impacts on state and national exams, high school attendance and attainment (Online Appendix Tables A.1, A.2, and A.3 show detailed estimates for the outcomes in the figure and additional related estimates). Boston charter school attendance boosts math scores by about half of a standard deviations (henceforth $\sigma$ ) and ELA scores by $0.32 \sigma$ two years after application. ${ }^{21}$ Boston charter attendance also increases AP test-taking and test scores and SAT test-taking and test scores. We also confirm in Figure 1 that Boston charter attendance increases time to high school graduation, with 4-year graduation rates reduced by 9 percentage points. There are no statistically significant differences in 5- or 6-year high school graduation rates. ${ }^{22}$ Boston charters boost enrollment in 4-year colleges by

\footnotetext{
${ }^{20}$ The first stage used in outcome estimation will vary slightly from the first row of Appendix Table C.7 due to different sample sizes and to only counting charter attendance in the years prior to an observed outcome. However, the vast majority of outcomes, including all of the voting outcomes, use any observed charter attendance after the lottery as endogenous variable in the first stage.

${ }^{21}$ To show test score impacts combining schools with different grade levels, we estimate impacts on the MCAS exams two years after charter school entrance: the 10th grade exam for schools that begin in 9th grade (the only high school MCAS exam), the 6th grade exam for schools that begin in 5th, and the 7th grade exam for schools that begin in 6 th.

${ }^{22}$ Note that graduation rates shown here will be lower than published graduation rates since we count students who
} 
7.2 percentage points, with about 40 percent of the effect due to an increase in enrollment in any college and about 60 percent due a switch from community colleges. ${ }^{23}$

Our findings are broadly in line with previous work on Boston charter schools. Test score estimates are quite similar to the 10th grade test score estimates in Abdulkadiroğlu et al. (2011) and ACDPW and, as expected, since we present two-year test score impacts here, about twice the per-year test score estimates in Abdulkadiroğlu et al. (2011), Cohodes et al. (2021), and Setren (2021). Charters continue to boost college preparation and college enrollment, as in ACDPW, but there are some differences in magnitudes which we show in Online Appendix Table D.1. We note that as a whole, our modeling choices will, if anything, depress the magnitude of our findings, meaning that we are taking a more conservative approach than prior work but still find substantial academic and college gains.

\section{Effects of charter schools on voting}

Students who attend Boston charter schools benefit academically, but do these educational gains extend beyond the classroom to civic participation? In this section, we show that this is the case, with our findings summarized in Figure 2. Though charter winners and losers appear on the Massachusetts voter rolls at similar rates, the charter winners are more likely to vote in presidential elections. The voting gains come almost entirely from a boost in girls voting in their first possible presidential election.

\subsection{Voter registration and voter participation}

Boston charter attendance makes little difference in the likelihood of registering to vote in Massachusetts, as can be seen in Panel A of Figure 2 (Columns 1-3 of Online Appendix Table A.4). Seventy-eight percent of control compliers are registered to vote, and charter attendance does not change this. ${ }^{24}$ As the voter files include only registered voters, these findings imply that we matched just over three-quarters of applicants to the voter file without differential matching by winner or loser status. We see that most voter registration takes place by students' 19th birthdays, with about 45 percent of students registering before they are 19, again with no difference by offer status. The vast majority of our sample of charter applicants are registered as Democrats (not shown), which is not surprising given their age, race, and economic background and that we study Massachusetts. ${ }^{25}$

have transferred out of state as non-graduates.

${ }^{23}$ We define college enrollment as enrollment for at least one semester of college within 18 months of expected high school graduation. This definition allows time for late high school graduates to enroll, though findings are similar when we restrict the college enrollment window to 6 months after high school graduation, as shown in Online Appendix Table E.1, which also shows differences by in-state and out-of-state college enrollment.

${ }^{24}$ Registering to vote in Massachusetts can be done online, through mail, or in person. Citizens are also automatically registered to vote when renewing a driver's licence or state ID at the RMV or when applying for health insurance through the state health exchange unless the individual opts out of registering. In Massachusetts, individuals may also pre-register to vote starting at 16 . Once they turn 18, their status is converted from pre-registered to registered and notified of this change to their voter record. The Massachusetts Secretary of State maintains the processes and procedures of registering to vote and voting, which can be found at https://www.sec.state.ma.us/ele/eleifv/howreg.htm.

${ }^{25}$ Perhaps because of these very high rates of Democratic support, we see no effects on party choice in registration or in presidential primary voting. Massachusetts has a semi-closed primary system where voters can only vote in the primary of their party but registered voters can switch party registration on election day. 
Charter attendance does affect voter participation, even if it does not change registration rates. Boston charters boost the rate at which students ever vote from about 64 percent to about 67 percent, a 3 percentage point increase (Panel B of Figure 2) though the difference is not statistically significant. This includes voting in any election in our voter files, including presidential elections, off-cycle general elections (for House members, Massachusetts governor, and Senate two-thirds of the time), presidential primary elections (held in February or March during our sample period), and other primary elections (usually held in September). The charter effect becomes marginally statistically significant when we look at the share of elections participated in, with charters boosting this by 3 percentage points.

However, when separated by election type, we see greater differences emerge, driven by presidential elections: Boston charter attendance increases voting in presidential elections (Panel C) but does not increase voting in non-presidential general elections or either type of primary (Panel D). However, turnout in all of the various non-presidential elections is generally very low, and only 14 percent of the charter applicant population votes in any off-cycle general election. For reference, fewer than 20 percent of 18to 29-year-olds voted in the 2014 election, with voting rates 40 percentage points higher for those ages 60 and above (McDonald, 2019, based on the CPS). We thus focus on presidential elections as our main outcome of interest given the high level of turnout there. ${ }^{26}$

Thus we turn to our key measure of voting: voting in the first possible presidential election. Boston charter attendance also boosts voting in the first possible presidential election (the first presidential election after a student turns 18) by about 6 percentage points (Panel $\mathrm{C}$ of Figure 2). The counterfactual voting rate is lower than that for ever voting, at about 35 percent. We focus on the first possible presidential election in order for there to be less time for students to leave Massachusetts or the region, and thus our sample. Additionally, the first possible presidential election is the election closest to the charter school treatment, and thus the one we think is most likely to show the influence of charter school attendance. We do show voting over time in Figure 3, which shows a persistent charter effect into the second possible presidential election but convergence by the third. It is not possible to determine if this reflects a shorter-term effect or if charter students are more likely to move out of state by the time of the third possible presidential election. To focus on a few key variables in our subsequent analyses, we primarily use the outcomes of ever registered, share voted of presidential elections, and voted in first possible presidential election.

The charter boost to voting for the full sample disguises a notable difference by gender, as shown in Figure 5. Girls outvote boys. In terms of voting in the first possible presidential election, the charter impact for young women is 11 percentage points for girls and none for boys. The difference is statistically significant $(p$-value $=0.038) .{ }^{27}$ It is the case that in more recent elections, women generally vote more

\footnotetext{
${ }^{26}$ Local elections may be interesting since they might be closer to the education policy process; however, we do not investigate municipal elections for several reasons. First, turnout in these elections is very low, making it difficult to detect differences across groups. In Boston, the relevant elections are for Mayor and City Council, which happen in non-presidential, non-general years; the school board is appointed by mayor. Additionally, many students move out of Boston and the relevant local elections will happen at different times in different communities, making it difficult to understand and thus to estimate impacts on which election is relevant to each student.

${ }^{27}$ There are more girls than boys in the charter school applicant pool in this study - a fact consistent with broader findings that girls are more likely to enroll in charter schools than boys (Corcoran and Jennings, 2018). However, the greater
} 
than men (Burns et al., 2018). We explore this difference by gender and the relationship with voting patterns of women and men in more detail in Section 7, and thus show impact estimates by gender for all voting outcomes in Online Appendix Tables A.4 and A.5.

We also examine whether the Boston charter attendance effect on voting varies by student background characteristics other than gender in Figure 4 (details in Online Appendix Table A.6). The gender difference is the most striking contrast, but there are some other meaningful differences by subgroup. Voting impacts are concentrated among students that receive subsidized lunch, which is likely due in part to the higher counterfactual voting rates for relatively higher-income students (33 percent for students with subsidized lunch versus 42 percent for students who do not receive a subsidy). Students with both low and high scores on their baseline MCAS exams and special education students, English learners, and those without special needs all have charter voting effects of similar size.

\subsection{Threats to validity}

Presidential elections occur only every four years, and each is unique. Below, we describe how removing each election from the sample in turn shows that no single election is driving the findings. We also consider other modifications to our specification, as well as how (lack of) residence in Massachusetts affects our findings. In short, Boston charters appear to boost voting across all presidential elections and the particular specification does not affect the conclusions. Students residing outside of Massachusetts likely bias downward the impacts on voting. Since our analysis of mechanisms revolves around gender, we show these robustness checks separately for all students, girls, and boys.

The first election of President Barack Obama in 2008 had record voter turnout. Additionally, the election of the first Black president in the United States may have influenced voter participation for Boston charter applicants - a majority of whom are African American. To determine if the charter voter effect is primarily driven by an interaction with the "Obama effect," we exclude students whose first possible presidential election was in 2008 in Row 2 of Online Appendix Table D.2. The charter effect on both share of presidential elections and first possible presidential election are a bit smaller (both are 4.3 percentage points, down from 5.0 and 5.8 in the baseline sample). The differential between boys and girls remains. We thus conclude that the first election of President Obama led to an even larger than typical boost in voting in the first possible presidential election but that the overall impact on voting patterns remains the same even excluding the original Obama voters. We also exclude cohorts for whom 2012 was the first possible election, noting that the Obama effect may exist for first time voters in 2012

number of girls does not account for the differences we see between genders, since we estimate impacts separately by gender. It is the case that having a larger number of girls in charter schools could contribute to a peer effect that contributes to the charter impacts, as classrooms with greater shares of girl students demonstrate such a peer effect (Hoxby, 2000; Lavy and Schlosser, 2011; Hu, 2015). However, the difference between Boston Public Schools (48 percent girls) and the charter applicant pool (52 percent girls) is small, as are the gender peer effects estimated elsewhere. If we take the estimates from Lavy and Schlosser (2011) impacts in Israel on high school tests, they imply that a 10 percent increase in share of girls in a classroom (about twice the difference we observe) would increase test scores by 0.02 to $0.3 \sigma$. This is quite a small share of the test score impacts we observe. A peer effect may operate differently for non-test outcomes, but Lavy and Schlosser (2011) also shows small gender peer effect impacts on high school graduation and none on behavior incidents. 
(row 3) and exclude cohorts for whom 2016 was the first possible presidential voting opportunity, noting that the 2016 contest was also unusual. ${ }^{28}$ Excluding the 2012 and 2016 cohorts increases standard errors, but voting impacts follow a very similar pattern as the overall results. The contrast between girls and boys remains for voting in the first possible presidential election, in both cases.

Other robustness checks in Online Appendix Table D.2 show few differences in charter impacts on voting outcomes. Excluding covariates does not affect the magnitudes or statistical significance of the results in a major way. Adding baseline scores increases the magnitude of the effects, but slightly changes who is in the sample (since baseline scores are available for a subset of students). Using charter attendance in the first two years after the charter lottery rather than attendance at any time before an outcome is observed as the endogenous variable results in essentially the same findings. Finally, using initial offer as the only instrument results in generally similar overall results with less statistical precision. A contrast remains between girls and boys but it is smaller in magnitude. Online Appendix Figures D.1 and D.2 show that excluding individual high school graduation cohorts or charter schools introduces small fluctuations in the magnitudes of voting effects but that they generally are quite similar and not driven by a particular cohort or school. In cases when the overall voting impact is not different from zero, the girl-boy contrast remains stark. Throughout all of these alternative specifications, girls consistently outvote boys in their first opportunity to vote, which increases our confidence in using the gender differential as the basis of our discussion of mechanisms in the Section 7.

Since Boston charter attendance increases enrollment in out-of-state colleges by 3.4 percentage points, as shown in Online Appendix Table E.1, the charter effect on voting may be underestimated if students vote in their college state rather than their home state. ${ }^{29}$ Within Massachusetts, charters shift students from 2-year institutions to 4-year institutions, while the out-of-state increases are all due to increased enrollment, mostly in 4-year institutions. Evidence from Online Appendix Table D.3, which shows voting outcomes for various samples, confirms that the increase in out-of-state college enrollment reduces voting, because we do not observe non-regional voting. ${ }^{30}$

A different way to show that the college attendance patterns of charter applicants likely underestimates the voting effect is in Online Appendix Table D.5. Here, we impute voter registration and voting for

\footnotetext{
${ }^{28}$ The 2020 election, also a very unusual election, contributes to our share and ever voted variables but not first possible presidential variables as our sample is not recent enough to examine first-time voters in the 2020 election.

${ }^{29}$ There is little evidence on where college students are registered. We are aware of one survey of college students about their voting during the 2004 election, which shows that two-thirds of college students are registered in their hometown, even when their college is located elsewhere (Niemi and Hanmer, 2010). We similarly find that most students who go to college out of state do not appear on the voter rolls in their new state, see Online Appendix Table B.1.

${ }^{30}$ When the sample is restricted to those students who attended 12th grade in Massachusetts, the charter attendance voter participation effect is slightly larger at 9 percentage points on voting in the first possible presidential election. In Appendix Table C.6, we show that charter lottery winners are no more likely to appear in the data in 12th grade, so the voting effect does not reflect differential likelihood of appearing in the data. For students that do not appear in the 12th grade data, counterfactual means on voter participation are lower and there is no impact of charter attendance. This likely reflects two situations. First, students who leave Massachusetts are much less likely to vote in Massachusetts. Second, individuals that drop out of high school are less likely to vote (McDonald, 2020). A similar pattern exists when excluding students who attend college out of state, however, and since charter attendance does affect the likelihood of attending an out-of-state institution, it is difficult to interpret the slightly larger impact on voting (9-10 percentage points).
} 
out-of-state college attendees. Our main specification (Panel A) already has a form of imputation: we assume all who do not show up in the Massachusetts voter file or that of a nearby state are non-voters. However, many of these students, especially those who move out of the area, may be voters in another state. Since most out-of-state college students are already included in our data as non-voters, when we impute zeroes for all out-of-state college students, as in Panel B, point estimates are only slightly different, and remain statistically significant. In Panel C, we assume that out-of-Massachusetts college attendees register and vote at the same rates as their counterparts in BPS attending 2- and 4-year institutions. Specifically, we impute a predicted voting outcome based on the voting rates of in-state college-going students in Boston Public Schools, separately for 4- and 2-year college attendees, adjusted for demographics. In this case, the overall charter first presidential voting impact jumps up to about 7.3 percentage points. This estimate likely also underestimates the impact of charter attendance on voting since it reflects the voting rates of BPS not including any charter effect. Panel D goes through the same exercise, but imputes voting only for college students out of the area for whom we have no out-of-state voter files. Both imputations show that, if anything, our estimates of the charter voting impact underestimate the extent to which charter school attendance boosts civic participation. Additionally, the girl-boy contrast remains under the imputations, indicating that the gender differential is not driven by differential likelihood of attending college out-of-state (and thus not appearing in our data).

\section{Mechanisms}

We anchor our investigation of the mechanisms behind the charter voting boost by leveraging the differential voting impacts by gender. As noted above, Figure 4 shows that the charter voting impact for the first presidential election for girls is 11.0 percentage points, while it is no different from zero for boys. This is the greatest contrast among subgroups, and it also corresponds with a well-known descriptive finding that women vote more frequently than men in recent United States elections Burns et al. (2018). The gender difference is also striking since prior charter school work in Boston has noted that boys and girls have similar test score and college impacts, though the declines in high school graduation are concentrated among boys (Angrist et al., 2016), which we also show in Online Appendix Tables A.2 and A.3. ${ }^{31}$

Political science research has shown that girls and boys have differing political participation and political preferences as early as age 14. Both Hooghe and Stolle (2004) and Fridkin and Kenney (2007) investigate the formation of political ideas among 8th graders, hypothesizing that 8th grade boys and girls should have little differences in traditional resources that contribute to the ability to vote, like economic situation or cognitive ability, and thus any differences at this point in time reflect differences in socialization. Hooghe and Stolle (2004) found that girls have greater intentions to vote than boys, and plan on participating in the political process more than boys, but that types of planned participation differ. Girls preferred "traditional" participation like voting, information gathering, volunteering, and peaceful

\footnotetext{
${ }^{31}$ In an intriguing parallel to our findings, Dobbie and Fryer (2020) use matching techniques to find that No Excuses schools in Texas generate academic gains that are similar by gender, or slightly favor boys, whereas earnings impacts from these schools seem to come only from girls $(p$-value $=0.113$ ) (Appendix Table A.10). If the underlying mechanisms behind earnings and voting are similar (and different from some of the academic gains), this pattern is consistent with what we find here.
} 
protest. However, boys were more likely to say they would run for office and participate in disruptive acts like painting slogans or occupying buildings. Fridkin and Kenney (2007) showed that girls were more likely to identify as Democrats and boys as Republicans, and girls had policy preferences for greater spending on social programs while boys had greater preferences for defense spending. These findings, though about 20 years old now, show that even as early as 14, the stage is set for differing political responses by gender.

We argue that outcomes that are influenced by the same underlying mechanism as the gender difference in voting rates should show a similar differential. That is, if the Boston charter effect for girls is larger than that for boys for another outcome consistent with a theoretical explanation of a particular channel for voting, then we have suggestive evidence of the importance of that particular mechanism. For example, if verbal skills determine differences in civic participation, we would expect the charter ELA score boost for girls to be larger than boys, paralleling the observed difference in voting. ${ }^{32}$

We show the gender differences for a selection of key outcomes associated with theoretical voting channels in Figure 5, with Online Tables A.1, A.2, A.3, A.4 and A.5 showing the full details of the estimates for the outcomes we highlight in the figure and others. We first note that the gender differential in voting does not seem to be explained by differences in educational attainment. While girls in Boston charter schools are just as likely as their counterfactual comparisons to graduate high school on time, charter school-attending boys are less likely to graduate overall. There is a gender difference here, but if this was the channel through which civic participation also operated, we would expect young women to have the same voting rates as their comparisons, and young men to vote less. This is the opposite of the voting behavior we observe. College enrollment also does not parallel the gender voting differential. Both boys and girls have a similar boost in 4-year college enrollment, yet Boston charter voting impacts are only from young women. ${ }^{33}$ This is also the case for persistence in 4-year institutions (shown in Online Appendix Table E.3).

Having described how the gender voting differential does not correspond to simple explanation in terms of educational attainment, we further use this strategy to explore outcomes associated with the cognitive skills, civic skills, noncognitive skills, and social network hypotheses. To explore the policy feedback channel, we use the voting records of charter school parents, described in detail below.

\subsection{Cognitive skills}

If greater cognitive skill increases voting by enhancing the ability of potential voters to engage with complex political topics, as suggested by Wolfinger and Rosenstone (1980); Verba et al. (1995); Nie et al. (1996), then we would expect that gains in academic skill should be similarly skewed towards girls, as is

\footnotetext{
${ }^{32}$ In Online Appendix Figures E.1a and E.1b, we extend this reasoning further, graphing the charter effects for various outcomes that correspond to theoretical channels against voter participation for each risk set by gender. The resulting figures then show the association between impacts on voting and other outcomes by risk set, separately for boys and girls. Differences between girls and boys in these figures are consistent with the exploration of mechanisms below. We focus on the overall gender impacts for simplicity.

${ }^{33}$ We can also examine whether the voting effect flows through college in a different way. In Online Appendix Table E.2, we show voter impacts for cohorts of students who turn 18 close to their first presidential election (when they would still be in, or have recently graduated from, high school) compared to impacts for cohorts who turn 18 a few years before their first presidential election. Overall impacts are generally similar across cohorts, but girls outvote boys to an even greater extent when students turn 18 close to their first presidential election, when they are most influenced by their secondary schooling experiences.
} 
the case for voting outcomes. Given that the theorized pathway comes through engagement with written materials, the predicted relationship, if it exists, should be larger for measures of verbal skill. In our setting, we can measure such skills with the state standardized exam, the MCAS.

Figure 5 shows Boston charter impacts by gender for both the MCAS ELA and math scores, two years after the charter school lottery. The impacts here are quite large, for both girls and boys. There is no difference in math scores between the two genders. The ELA score boost is larger for boys ( $p$-value of 0.182 ); which is the opposite direction of the voting impact. The lack of difference in math scores, and a difference in the opposite theoretical direction for ELA scores, gives little credence to the cognitive skills channel, especially since verbal skill is theorized as the main pathway for voting. ${ }^{34}$

\subsection{Civic skills}

If exposure to civics knowledge increases voting, we would expect girls to have a boost in civics skills similar to their voting differential. We do not have a direct measure of civics education curriculum; however, we do observe AP test-taking in related subjects: AP U.S. History and AP U.S. Government and Politics. We thus examine whether girls out-enroll boys in these courses in Figure 5. Enrollment in these courses is similar by gender. Attending a Boston charter boosts the likelihood that a student enrolls in a civicsfocused AP class by about 12.5 percentage points overall, with an increase of 13.7 percent for young women and 11.3 percent for young men. The gender difference is small and not statistically significant. Gains in scores on civics-related AP tests actually favor boys, rather than girls, which runs counter to the pattern in voting, and is likely due to boys having a very low counterfactual rate of scoring at least a 3 on one of these APs in the first place (Online Appendix Table A.2. The lack of a parallel between voting gains and enrollment and scores in civics-oriented APs lines up with the past literature that shows few links between formal civics curricula and civic participation (Manning and Edwards, 2014; Weinschenk and Dawes, 2021).

The evidence on APs does not show much scope for civics skills to explain the charter school impact on voting, but APs come towards the end of school and only 20 percent of charter students enroll in a civics-focused AP. Thus, we have another way to approach the civics skills pathway: we compare charter schools with explicit civic orientations in their mission statements to charter schools that do not have such a focus (their mission statements instead tend to focus on academics). In many other settings, civics curricula are just one-off courses, required by state law, and unsurprisingly have little impact on civics outcomes. An approach which embeds a civic-orientation more deeply into a school culture, rather than a add-on course, may be more successful at transmitting civic skills. This is the idea behind the Democracy Prep schools, which did show an impact on voting (Gill et al., 2020).

As such, we compare voting impacts between civics-oriented and non-civics oriented schools in the

\footnotetext{
${ }^{34}$ Boys do have a lower counterfactual ELA scores, and despite boys' larger gains, girls in charter schools still outscore boys overall (girls: $0.06 \sigma$, boys: $-0.22 \sigma$ ) which implies that if there is some threshold at which verbal performance drives civic participation, there is still scope for this channel to explain girls' voting dominance here. However, girls and boys have a similar boost in terms of a 7 to 8 percentage point gain in likelihood of scoring advanced-the highest level on the MCAS (Online Appendix Table E.3). The similar change in the percentage of boys and girls who pushed over that threshold implies that obtaining a high level of verbal ability likely does not explain the voting differences here, since, if very high verbal skills was the explanation, we'd expect a similar bump in voting for both boys and girls.
} 
Boston context. Online Appendix Table A.9 displays the charter school mission statements, collected from their websites. We categorized a school as civics-oriented if their mission statement mentioned "civic(s)," "citizenship," or "community." Non-civics-oriented mission statements tended to be focused on academics, and while they may mention topics "beyond" academics and college, they do not explicitly have a civics or communitarian focus. An example civics-oriented mission statement comes from the City on a Hill schools: "City on a Hill graduates responsible, resourceful, and respectful democratic citizens prepared for college and to advance community, culture, and commerce, and to compete in the 21st century..." An example of a not-civics-oriented mission statement comes from Boston Collegiate: "The mission of Boston Collegiate Charter School is simple yet ambitious: to prepare each student for college." College preparation could certainly involve a civics-orientation, but it is not an explicit part of the stated mission. Schools with a citizenship or community focus may be more analogous to the Democracy Prep schools studied in Gill et al. (2020), whose mission statement is: "The mission of Democracy Prep Public Schools is to educate responsible citizen-scholars for success in the college of their choice and a life of active citizenship."

To estimate impacts for each of the two school types, we modify Equations 1 and 2 by separately enumerating offer and enrollment variables for civics- and non-civics-oriented campuses. This multiple endogenous variable approach has also been used in Angrist et al. (2013b) and Cohodes et al. (2021) to estimate charter effects by school type. We show the results from this setup in Figure 6, which reports separately the charter attendance effect for each school type from jointly estimated regressions. Civics-oriented charter schools have slightly larger impacts compared to non-civics-oriented charters on ever voting in Massachusetts (8 percentage points versus 4 percentage points) and voting in the first possible presidential election ( 7 percentage points versus 4 percentage points). However, these differences are well within the variation we would expect given a small number of schools, with $p$-values for the differences across school types indicating no statistically significant differences. Furthermore, when we split by gender (Online Appendix Table A.8), the effects are strongest for girls in non-civics-oriented charter schools, though the differences across mission-type within gender are not statistically significant. We thus conclude that a broader school-level civics-orientation does not explain the charter voting impacts.

\subsection{Noncognitive skills}

Along similar lines to the cognitive and civic skills channels, if charter schools boost voting for girls and not boys and noncognitive skills explain that difference, we expect that a measure of noncognitive skills will increase for girls to a greater extent as well. Our data has no direct measure of noncognitive skills, which in other cases is typically a survey-based measure of self-control or grit. This is a limitation of our study, and is a contrast to Holbein (2017)'s study of Fast Track, which studies an intervention specifically designed to increase psycho-social skills (which later increases voting), and thus has more direct measures of these skills. However, there is reason to believe that self-reports of noncognitive skills in the Boston charter sector may not accurately reflect noncognitive skills. West et al. (2016) find that Boston charter school students score lower on self-reported measures of noncognitive skills, despite attending schools that increase academic scores, attendance, and seem likely to provide scaffolding for noncognitive skills 
given their emphasis on conduct and learning. The authors explain that their findings are likely due to charter schools changing the reference point for the context-dependent survey measures used to construct noncognitive skill indices - so that charter students have a different definition of things that reflect grit, self-control, etc. - and that there likely are actual skill gains in these dimensions.

Thus, in lieu of a direct measure of noncognitive skills, we use days of high school attendance and taking the SAT as a proxies, since they are related to persistence and follow-through. ${ }^{35}$ As voting in the United States often involves navigating sign-up processes, planning ahead, and following through, having the skills to navigate such challenges is a channel that could plausibly affect voting. Attendance is often used as a proxy for noncognitive skills (Gershenson, 2016; Holbein and Ladd, 2017; Jackson, 2018; Jackson et al., 2020). ${ }^{36}$ Holbein et al. (2020) shows an association between grit and attendance. Holbein and Hillygus (2020) argue that this "observed behavior" approach, which relies on administrative data, identifies a factor separate from cognitive skills and family background (p. 56).

We show overall Boston charter impacts on days of high school attendance in Online Appendix Table A.1, summarized in Panel B of Figure 1, both of which show that charters boost days attended throughout high school. ${ }^{37}$ The largest attendance difference is in 9th grade, where charter enrollment increases attendance by 4.6 days, while over the course of the high school career, charters induce an increase of 12 days of school attended. Since charter schools typically have a longer school year than than district counterparts, we also calculate the charter impact on attendance rate. Here, charters do a little bit worse than their counterparts, with charter attendance reducing the proportion of days attended.

In Figure 5 (visualized as attendance above median attendance) and Online Appendix Table A.1 we show that the 12-day charter boost in high school attendance disguises considerable heterogeneity. Separating impacts by gender shows that the attendance effect, like the voting effect, operates entirely via girls. Young women attend 22 more days of school then their counterfactual counterparts; there is no difference for young men. ${ }^{38}$ The gender difference is statistically significant $(p$-value $=0.006)$. This evidence cannot causally prove that noncognitive skills - proxied by attendance - caused the boost in voting. However, the alignment by gender on both of these outcomes (and the absence of alignment for other outcomes) is suggestive that charter schools' impacts on noncognitive skills are a meaningful path for civic participation.

A similar pattern comes from the evidence on taking the SAT. Taking the SAT is not unlike voting,

\footnotetext{
${ }^{35}$ While utilizing high school attendance and taking the SAT are imperfect measures of noncognitive skills, we use logic similar to Holbein et al. (2020), who emphasize that "Voting takes time, energy, motivation, and effort." While there are no direct measure of noncognitive skills in our data, signing up and taking the SAT demonstrates not only intention, but also the ability to follow through similar to registering to vote and actually voting.

${ }^{36}$ Some of these papers use suspensions, tardies, and GPAs as additional (or aggregated) measures of noncognitive skills, but we do not use them here since suspensions and GPAs may function inside schools very differently in the charter and non-charter context.

${ }^{37}$ Attendance data is only available for students for whom we observe enrollment in Massachusetts schools. Thus, we also report the charter impact on likelihood of appearing in the data. There is no overall difference in the likelihood of appearing in the data over the course of high school, though only about 70 percent of the sample is present throughout all four grades. In 9th grade, charter students are slightly more likely to appear in the data, and in 12th grade, charter school boys are more likely to not appear in the data.

${ }^{38}$ For attendance rate gender differences, there is no difference for girls in terms of their attendance, whereas boys drive the negative impacts on proportion of days attended.
} 
as one needs perseverance to stick it out: one must register in advance, show up to an often non-standard location at a particular time, and take part in a time-consuming task. Attending a charter school boosts the SAT-taking rate by 5 percentage points, as shown in Online Appendix Table A.2, but the increase is 8 percentage points for girls and only 2 percentage points for boys. The difference is not statistically significant $(p$-value $=0.305)$, but alongside the evidence on attendance, it shows that charters appear to shift noncognitive skills more for girls than boys, and that these differences align with the observed pattern in voting gains.

\subsection{Social networks}

Education has the potential to change social networks. In particular, students enter new communities when they matriculate to college. We see in Figure 1 that Boston charters induce enrollment in 4-year colleges, likely exposing students to different communities than they would have been in otherwise. If college communities have a more pervasive norm of civic participation than students' home communities, or if college-going better connects students to the political process through interaction with elites, college education may induce voting through these social connections.

We do not have a direct measure of individuals' social networks, but we can measure the civic participation rates of communities that students enter via college in two different ways. Using all non-charter students in Massachusetts in the same time period, we measure the Massachusetts voting rates at all post-secondary institutions that Massachusetts students attend, based on first college attended in the NSC data. That is, we take the voting records of all Massachusetts' non-charter students attending, for example, the University of Massachusetts at Amherst, and calculate the voting rate of that population. We then assign voting rates by college community based on first institution attended in the lottery sample. Students who do not attend college are assigned the voting rate of Boston students who do not attend college. ${ }^{39}$ This outcome then defines the change in community voting rate for a similar age population, as induced by changing communities due to attending college.

Since communities' civic values are defined by more than just the voting rates of young people, we define a second measure of community voting engagement, using the community turnout rate at the county level collected in Dave Leip's Atlas of U.S. Presidential Elections, which compiles election data from primary sources. ${ }^{40}$ College location data from IPEDS identifies the county of each student's first post-secondary institution. We match that location to two measures of county-level voter engagement: total votes cast divided by the number of registered voters in the county (community turnout rate), and registered voters divided by total population (community registration rate). Registration and voting information comes from the year of the most recent presidential election prior to students' high school graduation, as a measure of the community civic participation that exists prior to students joining that community. Students who did not attend college and those who attended large, online schools like ITT Technical Institute for whom we cannot determine a specific county are assigned to Boston's Suffolk County as a default, which assumes they

\footnotetext{
${ }^{39}$ Students who attend colleges with fewer than 10 Massachusetts students are assigned college community voting rates by college sector.

${ }^{40}$ See https://uselectionatlas.org/https://uselectionatlas.org/.
} 
do not move away from Boston after they entered the charter lottery. In the case of both the college voting rate and the community rates, we cannot account for community changes that are not induced by college.

Overall, charter schools - by inducing students to attend colleges, particularly colleges outside of their home community - push students into communities that have slightly higher voting rates, as seen in Online Appendix Table A.10. The registration and voting rates, defined by Massachusetts high schoolers, are about 1.4 to 1.8 percentage points higher than the rates in the counterfactual condition. County-level turnout is also about half a percentage point higher, again showing that charters move students to social contexts with higher civic participation rates. However, as shown in Figure 5 and Online Appendix Table A.10, there are no statistically significant differences in these college community voting rates for girls and boys, which does not suggest a role for social networks in explaining the charter voting boost.

However, we do not directly observe social interactions, and it may very well be the case that young women have wider social networks or take advantage of the social networks in college to a greater extent than boys, enabling the social network mechanism for them but not young men, which would be consistent with the observed pattern of voting results. We see a hint of this in Figure 5, which shows the charter school impact on being the only person of one's gender from one's high school graduating class to attend one's college (which we label as "Solo College Attendee.") This outcome is a proxy for how much a student would need to enter new social networks in college, not having any connections from high school to rely on. Attending a charter increases the likelihood of entering college without an extant social network by 6 percentage points; for girls the bump is 9 percentage points versus 3 percentage points for boys. The difference is not statistically significant $(p$-value $=0.165)$ and our measure is only a proxy for new social networks (see Online Appendix Table E.3 for details). But it does show some potential for social networks to explain the charter voting effect. Overall, without an actual measure of social networks, we can neither confirm such networks as the channel for voting impacts, nor can we completely eliminate it.

\subsection{Policy feedback}

Our test for the policy feedback channel differs from the tests for the other mechanisms. Rather than comparing impacts by gender, we turn to parent voting behavior. Contact with the charter schools could politicize both parents and students, especially as the question of charter schools has become more politically polarizing (Reckhow et al., 2015). ${ }^{41}$ In 2016, for example, voters in Massachusetts rejected a ballot initiative to expand charter schools. More than $\$ 42 \mathrm{M}$ was spent for and against the measure - more than twice what was spent, cumulatively, on three other ballot initiatives that election year in Massachusetts. Additionally, while there could be skill or network spillovers from children to their parents, parents (and their civic participation) are much less likely to be directly affected by anything happening at school. If there are no voting effects for parents, unlike the effects on the students, that suggests one of the skill channels or a social network channel is likely causing the charter voting impacts. If there is a difference for parents, that gives

\footnotetext{
${ }^{41}$ Winning or losing a charter lottery could also change the political advocates parents are in contact with, though we lack the right empirical experiment to address this directly. With children attending charters, parents might be more exposed to education reformers; parents with children at public schools might be more connected to teachers unions and anti-charter advocates.
} 
credence to the policy feedback mechanism, though the mechanisms for parents and students may differ.

It is also possible that having a child attend a charter school could make parents less likely to vote, as charter schools are a form of government privatization that may lead parents to become less involved or connected to government. Cook et al. (2020) show some evidence that this occurs, though they rely on existence of charter schools rather than direct evidence from charter lotteries. ${ }^{42}$ Regardless of the direction of parent voting, we interpret parent voting as the best channel to test the policy feedback mechanism.

\subsubsection{Estimating parent voting impacts}

The analysis sample differs for parents. First, not all of the lottery records that schools provided us included parent information, and this differed by year within charter schools. We thus exclude all lotteries without parent information as well as those that have parent information, but only for a subset of parents, typically parents of students on the waitlist. We also include some more recent lotteries that had parent information but for whom the students involved were not yet 18 by the 2016 election. This resulted in a student sample size about three-quarters of the size of our main sample. We show in Online Appendix Table F.1 that there are no differences by offer status in terms of student characteristics, which, as in the main sample, is consistent with no manipulation of the lotteries themselves.

There are also some differences in the matching and estimation strategies. We use parent name information to match to the voter files, limited to voters residing in Boston. We augment our Massachusetts voter files with an earlier Boston voter file from 2009 to be able to include parents who were registered circa 2009 but may have moved away or dropped their registration prior to our later files. ${ }^{43}$ We have no consistent, additional parent information like date of birth or address, so we cannot differentiate between cases when a parent has a common name and matches to multiple people in the voter file. ${ }^{44}$ We thus do not conduct any fuzzy matching exercises, since we do not have any audit information to help make a confirmatory match.

We account for multiple matches, which occur when a parent has a common name, by presenting several models that include or exclude multiple matches in different ways. The three models are: 1) including all matches and clustering standard errors at the student level; 2) eliminating multiple matches and limiting the analysis sample to those who match to only one name or no name in the voter file, or 3) collapsing the data to the student level, which averages multiple matches. Since students can have two parents associated with them, even without the multiple matches, we would include all parent information and cluster our standard errors at the student level, or collapse the data with an average at the student level. Additionally, we present each sample with and without inverse propensity to match weights, based on demographics and name characteristics.

In Online Appendix Table F.2, we examine parent name characteristics by lottery offer status. Overall,

\footnotetext{
${ }^{42}$ Alternatively, voter participation could decrease for parents of charter lottery losers as losing the lottery may increase distrust in government systems, as in school choice lottery losers in Hastings et al. (2007).

${ }^{43}$ This file does not contribute to our student analysis since students in our sample are generally yet old enough to vote in 2009 and it is restricted to Boston only.

${ }^{44}$ We have limited address data for about one-third of the parent sample, which often confirmed correct matches. However, we do not use this information to refine cases with multiple matches since it is only available for a small subset of parents and families may move.
} 
the vast majority of lottery records in the parent analysis sample (98.5\%) have parent information (Panel A), with no differences for students who receive an offer. For the students that do have parent name information, Panel B shows that the length and commonness of their name is the same by offer status. The last panel, Panel C, shows that there is no difference in terms of matching to only a single voting record or to multiple voting records, which is expected based on similar name characteristics.

\subsubsection{Testing the policy feedback mechanism}

A child's charter school attendance appears to have no impact on the likelihood that a parent votes, as can be seen in Table 2. For all samples, with all weights, the charter impact on parents' voting after the lottery is small and indistinguishable from zero, whether measured by voting in the first possible presidential election, voting in any presidential election, or voting in the 2016 election. We focus on the 2016 election in particular, when charter schools may have directly encouraged parents to vote given the charter school cap ballot measure in that election, but still find no effect on parental voting.

Because parents have a voting history prior to interacting with a charter school, unlike in the student sample, we can examine a placebo outcome: voting in elections before a child participates in the charter school lottery. Since there is no possible way a child's charter school attendance could affect civic behavior prior to it occurring, any "impacts" we found here would imply some sort of bias in our estimation strategy. This placebo test is shown in Columns 6 of Table 2, which reports impacts on presidential elections prior to the relevant charter school lottery in our sample. Point estimates are quite small, and none are statistically significant, indicating that our estimation strategy is sound. Additionally, comparing the control complier mean from the election before the lottery to the one after the lottery shows similar voting rates. This demonstrates that, unlike in Hastings et al. (2007), losing the lottery did not spur political participation for parents of students who missed the opportunity to attend. As a whole, we interpret the parent voting evidence to imply no policy feedback effect, at least for adults.

\subsection{Summarizing the evidence on mechanisms}

None of our exercises above can causally link the charter school voting gain to a particular mechanism. However, by highlighting when outcomes related to specific theorized mechanisms align with the observed gender differences in voting, as well as other related explanations, we show evidence that is consistent with some channels and not with others. The alignment between attendance and SAT-taking gains for girls with the voting increase for girls, and lack of increase in each of these outcomes for boys, is consistent with noncognitive skills being a primary mechanism for the voting effect. In the case of both civic skills and social networks, we don't have strong confirmatory evidence that either explains the voting gains, though we do not have perfect tests of either potential channel. Evidence from parent voting is not suggestive of the policy feedback mechanism. However, when it comes to the cognitive channel, our evidence strongly points to it not being an explanation for any voting gains that we see.

Since our evidence on noncognitive skills has the most support of the five mechanisms we test, we discuss that channel more deeply here. The noncognitive skill gains we observe by gender are 
consistent with prior research that shows girls have greater noncognitive skills than boys and maintain that differential through school. Girls begin kindergarten with greater noncognitive skills than boys, and maintain their advantage through elementary school (DiPrete and Jennings, 2012; Bertrand and Pan, 2013). In eighth grade, girls have greater self-discipline than boys (Duckworth and Seligman, 2006). Autor et al. (2019) show that behavioral gender gaps are greater among disadvantaged children. These differences in noncognitive skills can affect longer-term outcomes: Jacob (2002) shows that greater noncognitive skills among girls, as proxied by middle school GPA, hours spent on homework, disciplinary record, and grade retention, explains 40 percent of the gender gap in college attendance. There is also work from interventions that show that girls may gain more noncognitive skills from educational interventions. Martins (2017) shows that a remediation program in Portugal designed to boost middle school students' noncognitive skills benefits girls to a much greater extent than boys. Similarly, a program designed to increase study habits and organization for Spanish high school students increased academic outcomes and noncognitive skills for both genders, though girls outperform boys (Battaglia et al., 2020).

None of the interventions discussed above track voting, but their findings showing girls' noncognitive gains, and ours showing girls' noncognitive and voting gains, align with Wang's (2014) findings that out of the Big Five personality traits, conscientiousness and emotional stability increase women's voter turnout but do not do so for men. ${ }^{45}$ Thus, girls - perhaps because of socialization - are more likely to turn gains in noncognitive skills into voting.

There are also a number of educational interventions that benefit girls over boys when outcomes such as test scores, college enrollment, and wages are measured (Hastings et al., 2006; Anderson, 2008; Angrist et al., 2009; Angrist and Lavy, 2009; Jackson, 2010; Lavy and Schlosser, 2011; Legewie and DiPrete, 2012; Lavy et al., 2012; Rodriguez-Planas, 2012; Deming et al., 2014; Clark and Del Bono, 2016; Carrell and Sacerdote, 2017; Beuermann and Jackson, 2020). These papers do not directly show that noncognitive skills are a component of student gains, but, together with our evidence, they are suggestive that education has benefitspotentially driven by noncognitive skills - for girls but not boys, that are realized in adult outcomes.

\section{Discussion}

In this paper, we show that Boston charter schools not only generate impressive educational gains but also boost civic participation. Voting impacts are large for young women but small or nonexistent for young men. These gendered effects are the first causal estimates that lend support to existing theories that gains in education play a role in the gender gap in political participation (Cascio and Shenhav, 2020; Burns et al., 2018).

Our estimated variation in charter effects on voting also pushes us to test which additional aspects of the charter school treatment vary by gender, hypothesizing that aspects that covary with the gender voting difference point to plausible mechanisms behind charter voting gains. When it comes to charter school students, the noncognitive skills induced by charter attendance seem the most likely channel for the turnout boost. We see this through increases in attendance and SAT-taking for girls, but not for

\footnotetext{
${ }^{45}$ The "Big Five" are often used in psychological research to summarize personality traits, comprising: extraversion, agreeableness, openness to experience, conscientiousness, and neuroticism.
} 
boys. We have no evidence that corresponds to traditional cognitive gains or policy feedback driving voting, and the evidence for civic education and social networks, while not conclusive, is weak.

We emphasize that while we found the main beneficiaries of the civic gains were young women, which corresponded to their larger gains in noncognitive skills, education's contribution to voting need not operate solely through girls. Interventions that increase noncognitive skills for boys may have similar effects, though we do not observe them in this context. It is also possible that education, and charter schools specifically, are set up in such a way that they particularly develop the skills of girls but not boys. While ACDPW previously noted that the Boston charter school educational gains for boys that are on par with those for girls stand in contrast to a number of educational interventions that show impacts for girls but not boys (Hastings et al., 2006; Anderson, 2008; Angrist et al., 2009; Angrist and Lavy, 2009; Jackson, 2010; Lavy and Schlosser, 2011; Legewie and DiPrete, 2012; Lavy et al., 2012; Rodriguez-Planas, 2012; Deming et al., 2014; Clark and Del Bono, 2016; Carrell and Sacerdote, 2017; Beuermann and Jackson, 2020), our evidence shows that when it comes to noncognitive skills and related, important life outcomes, charter schools may have the same gender differentials as found elsewhere.

This raises the question of what it is about school that provides greater benefits to girls than to boys. We know that girls begin school with an advantage in noncognitive skills that they maintain throughout (DiPrete and Jennings, 2012; Bertrand and Pan, 2013; Duckworth and Seligman, 2006). If, as Heckman and colleagues (2014) suggest, "skills beget skills," these differences could compound throughout school. For example, Terrier (2020) shows that teachers grade girls more favorably than boys and that these advantages compound over time, an idea supported by work from Conger (2015), which shows that girls' higher grades contribute to their advantage in college enrollment. Inasmuch as an academically focused charter school is an even more intense version of school, these differences may be compounded even further. 


\section{References}

Abadie, A. (2002). Bootstrap tests for distributional treatment effects in instrumental variables models. Journal of the American Statistical Association 97(457), 284-292.

Abdulkadiroğlu, A., J. Angrist, S. Dynarski, T. J. Kane, and P. Pathak (2011). Accountability and flexibility in public schools: Evidence from Boston's charters and pilots. The Quarterly Journal of Economics 126(2), 699-748.

Abdulkadiroğlu, A., J. D. Angrist, P. Hull, and P. A. Pathak (2016). Charters without lotteries: Testing takeovers in New Orleans and Boston. American Economic Review 106(7), 1878-1920.

Abdulkadiroğlu, A., J. D. Angrist, Y. Narita, and P. A. Pathak (2017). Research design meets market design: Using centralized assignment for impact evaluation. Econometrica 85(5), 1373-1432.

Abrams, S., T. Iversen, and D. Soskice (2011). Informal social networks and rational voting. British Journal of Political Science, 229-257.

Akee, R., W. Copeland, J. B. Holbein, and E. Simeonova (2020). Human capital and voting behavior across generations: Evidence from an income intervention. American Political Science Review 114(2), 609-616.

Anderson, M. L. (2008). Multiple inference and gender differences in the effects of early intervention: A reevaluation of the abecedarian, perry preschool, and early training projects. Journal of the American statistical Association 103(484), 1481-1495.

Angrist, J., D. Lang, and P. Oreopoulos (2009). Incentives and services for college achievement: Evidence from a randomized trial. American Economic Journal: Applied Economics 1(1), 136-63.

Angrist, J. and V. Lavy (2009). The effects of high stakes high school achievement awards: Evidence from a randomized trial. American economic review 99(4), 1384-1414.

Angrist, J., P. Pathak, and C. Walters (2013a). Explaining charter school effectiveness. American Economic Journal: Applied Economics 5(4), 1-27.

Angrist, J. D., S. R. Cohodes, S. M. Dynarski, P. A. Pathak, and C. R. Walters (2016). Stand and deliver: Effects of Boston's charter high schools on college preparation, entry, and choice. Journal of Labor Economics 34(2), 275-318.

Angrist, J. D., S. M. Dynarski, T. J. Kane, P. A. Pathak, and C. R. Walters (2012). Who benefits from KIPP? Journal of Policy Analysis and Management 31(4), 837-860.

Angrist, J. D., P. a. Pathak, and C. R. Walters (2013b). Explaining Charter School Effectiveness. American Economic Journal: Applied Economics 5(4), 1-27.

Autor, D., D. Figlio, K. Karbownik, J. Roth, and M. Wasserman (2019). Family disadvantage and the gender gap in behavioral and educational outcomes. American Economic Journal: Applied Economics 11(3), 338-81.

Battaglia, M., M. Hidalgo-Hidalgo, et al. (2020). Non-cognitive skills and remedial education: Good news for girls. Working paper. 
Berinsky, A. J. and G. S. Lenz (2011). Education and political participation: Exploring the causal link. Political Behavior 33(3), 357-373.

Bertrand, M. and J. Pan (2013). The trouble with boys: Social influences and the gender gap in disruptive behavior. American economic journal: applied economics 5(1), 32-64.

Beuermann, D. W. and C. K. Jackson (2020). The short and long-run effects of attending the schools that parents prefer. Journal of Human Resources.

Brady, H. E., S. Verba, and K. L. Schlozman (1995). Beyond ses: A resource model of political participation. American political science review 89(2), 271-294.

Bross, W., D. N. Harris, and L. Liu (2016). The effects of performance-based school closure and charter takeover on student performance. Technical report, Education Research Alliance for New Orleans.

Buckley, J. and M. Schneider (2009). Charter schools: Hope or hype? Princeton University Press.

Burns, N., K. L. Schlozman, A. Jardina, S. Shames, and S. Verba (2018). What's happened to the gender gap in political participation?: How might we explain it? In 100 Years of the Nineteenth Amendment: An Appraisal of Women's Political Activism, pp. 69-104. Oxford University Press.

Burns, N., K. L. Schlozman, and S. Verba (2002). The Private Roots of Public Action: Gender, Equality, and Political Participation. Harvard University Press.

Campbell, D. E. (2013). Social networks and political participation. Annual Review of Political Science 16, 33-48.

Campbell, D. E. (2019). What social scientists have learned about civic education: A review of the literature. Peabody Journal of Education 94(1), 32-47.

Carrell, S. and B. Sacerdote (2017, July). Why do college-going interventions work? American Economic Journal: Applied Economics 9(3), 124-51.

Cascio, E. U. and N. Shenhav (2020). A century of the american woman voter: Sex gaps in political participation, preferences, and partisanship since women's enfranchisement. Journal of Economic Perspectives 34(2), 24-48.

Chabrier, J., S. Cohodes, and P. Oreopoulos (2016). What can we learn from charter school lotteries. Journal of Economic Perspectives 30(3), 57-84.

Chetty, R., J. N. Friedman, and J. E. Rockoff (2014). Measuring the impacts of teachers I: Evaluating bias in teacher value-added estimates. American Economic Review 104(9), 2593-2632.

Chevalier, A. and O. Doyle (2012). Schooling and voter turnout: Is there an American exception? IZA Discussion Papers 6539, Institute of Labor Economics (IZA).

Chyn, E. and K. Haggag (2019). Moved to vote: The long-run effects of neighborhoods on political participation. Working paper 26515, National Bureau of Economic Research.

Clark, D. and E. Del Bono (2016). The long-run effects of attending an elite school: Evidence from the United Kingdom. American Economic Journal: Applied Economics 8(1), 150-76. 
Cohodes, S. R. (2016). Teaching to the student: Charter school effectiveness in spite of perverse incentives. Education Finance and Policy 11(1), 1-42.

Cohodes, S. R. and K. S. Parham (2021). Charter schools' effectiveness, mechanisms, and competetive influence. National Bureau of Economic Research Working Paper 28477.

Cohodes, S. R., E. M. Setren, and C. R. Walters (2021). Can successful schools replicate? Scaling up Boston's charter school sector. American Economic Journal: Economic Policy 13(1), 138-67.

Conger, D. (2015). High school grades, admissions policies, and the gender gap in college enrollment. Economics of Education Review 46, 144-147.

Cook, J. B., V. Kogan, S. Lavertu, and Z. Peskowitz (2020). Government privatization and political participation: The case of charter schools. The Journal of Politics 82(1), 300-314.

Corcoran, S. P. and S. A. Cordes (2015). The continuing impact of democracy prep public schools: Preliminary report. Working paper.

Corcoran, S. P. and J. Jennings (2018). The gender gap in charter school enrollment. Educational Policy 32(5), 635-663.

Croke, K., G. Grossman, H. A. Larreguy, and J. Marshall (2016). Deliberate disengagement: How education can decrease political participation in electoral authoritarian regimes. American Political Science Review 110(3), 579-600.

Curto, V. E. and R. G. Fryer (2014). The potential of urban boarding schools for the poor: Evidence from SEED. Journal of Labor Economics 32(1), 65-93.

Davis, M. and B. Heller (2019). No excuses charter schools and college enrollment: New evidence from a high school network in Chicago. Education Finance and Policy 14(3), 414-440.

Dee, T. S. (2004). Are there civic returns to education? Journal of Public Economics 88(9-10), 1697-1720.

Deming, D. J., J. S. Hastings, T. J. Kane, and D. O. Staiger (2014). School choice, school quality, and postsecondary attainment. American Economic Review 104(3), 991-1013.

Dinesen, P. T., C. T. Dawes, M. Johannesson, R. Klemmensen, P. Magnusson, A. S. Nørgaard, I. Petersen, and S. Oskarsson (2016). Estimating the impact of education on political participation: Evidence from monozygotic twins in the United States, Denmark and Sweden. Political Behavior 38(3), 579-601.

DiPrete, T. A. and J. L. Jennings (2012). Social and behavioral skills and the gender gap in early educational achievement. Social Science Research 41(1), 1-15.

Dobbie, W. and R. Fryer (2011). Are high quality schools enough to increase achievement among the poor? American Economic Journal: Applied Economics 3(3), 158-187.

Dobbie, W. and R. Fryer (2013). Getting beneath the veil of effective schools: Evidence from New York City. American Economic Journal: Applied Economics 5(4), 28-60.

Dobbie, W. and R. Fryer (2015). The medium-term impacts of high-achieving charter schools. Journal of Political Economy 123(5), 985-1037. 
Dobbie, W. and R. G. Fryer (2020). Charter schools and labor market outcomes. Journal of Labor Economics 38(4), 915-957.

Downs, A. (1957). An economic theory of democracy. Harper New York.

Duckworth, A. L. and M. E. Seligman (2006). Self-discipline gives girls the edge: Gender in self-discipline, grades, and achievement test scores. Journal of educational psychology 98(1), 198.

Epple, D., R. Romano, and R. Zimmer (2016). Charter schools: A survey of research on their characteristics and effectiveness. In Handbook of the Economics of Education, Volume 5, pp. 139-208. Elsevier.

Felix, M. (2020). Charter schools and suspensions: Evidence from Massachusetts.

Fortson, K., P. Gleason, E. Kopa, and N. Verbitsky-Savitz (2015). Horseshoes, hand grenades, and treatment effects? reassessing whether nonexperimental estimators are biased. Economics of Education Review 44, 100-113.

Fridkin, K. L. and P. J. Kenney (2007). Examining the gender gap in children's attitudes toward politics. Sex Roles 56(3), 133-140.

Friedman, W., M. Kremer, E. Miguel, and R. Thornton (2016). Education as liberation? Economica 83(329), 1-30.

Gallego, A. (2010). Understanding unequal turnout: Education and voting in comparative perspective. Electoral Studies 29(2), 239-248.

Gershenson, S. (2016). Linking teacher quality, student attendance, and student achievement. Education Finance and Policy 11(2), 125-149.

Gilens, M. and B. I. Page (2014). Testing theories of American politics: Elites, interest groups, and average citizens. Perspectives on politics 12(3), 564-581.

Gill, B., E. R. Whitesell, S. P. Corcoran, C. Tilley, M. Finucane, and L. Potamites (2020). Can charter schools boost civic participation? The impact of Democracy Prep Public Schools on voting behavior. American Political Science Review 114(4), 1386-1392.

Goldin, C. and L. F. Katz (2010). The race between education and technology. Harvard University Press.

Goldin, C., L. F. Katz, and I. Kuziemko (2006). The homecoming of american college women: The reversal of the college gender gap. Journal of Economic perspectives 20(4), 133-156.

Green, D. P., P. M. Aronow, D. E. Bergan, P. Greene, C. Paris, and B. I. Weinberger (2011). Does knowledge of constitutional principles increase support for civil liberties? Results from a randomized field experiment. The Journal of Politics 73(2), 463-476.

Hansen, M., E. Levesque, J. Valant, and D. Quintero (2018). The 2018 Brown Center report on american education: How well are American students learning. Washington, DC: The Brookings Institution.

Harris, D. and M. Larsen (2019). The effects of the New Orleans post-Katrina market-based school reforms on medium-term student outcomes. Education Research Alliance for New Orleans. 
Hastings, J. S., T. J. Kane, and D. O. Staiger (2006). Gender and performance: Evidence from school assignment by randomized lottery. American Economic Review 96(2), 232-236.

Hastings, J. S., T. J. Kane, D. O. Staiger, and J. M. Weinstein (2007). The effect of randomized school admissions on voter participation. Journal of Public Economics 91(5-6), 915-937.

Hastings, J. S., C. A. Neilson, and S. D. Zimmerman (2012). The effect of school choice on intrinsic motivation and academic outcomes. National Bureau of Economic Research Working Paper 18324.

Hillygus, D. S. (2005). The missing link: Exploring the relationship between higher education and political engagement. Political behavior 27(1), 25-47.

Holbein, J. B. (2017). Childhood skill development and adult political participation. American Political Science Review 111(3), 572-583.

Holbein, J. B. and D. S. Hillygus (2016). Making young voters: The impact of preregistration on youth turnout. American Journal of Political Science 60(2), 364-382.

Holbein, J. B. and D. S. Hillygus (2020). Making young voters: Converting civic attitudes into civic action. Cambridge University Press.

Holbein, J. B., D. S. Hillygus, M. A. Lenard, C. Gibson-Davis, and D. V. Hill (2020). The development of students' engagement in school, community and democracy. British Journal of Political Science 50(4), $1439-1457$.

Holbein, J. B. and H. F. Ladd (2017). Accountability pressure: Regression discontinuity estimates of how No Child Left Behind influenced student behavior. Economics of Education Review 58, 55-67.

Hooghe, M. and D. Stolle (2004). Good girls go to the polling booth, bad boys go everywhere: Gender differences in anticipated political participation among american fourteen-year-olds. Women $\&$ Politics 26(3-4), 1-23.

Hoxby, C. and J. Rockoff (2004). The impact of charter schools on student achievement. National Bureau of Economic Research Conference Paper, June.

Hoxby, C. M. (2000). Peer effects in the classroom: Learning from gender and race variation. National Bureau of Economic Research Working Paper 7867.

Hoxby, C. M., J. L. Kang, and S. Murarka (2009, September). Technical Report: How New York City Charter Schools Affect Achievement,. National Bureau of Economic Research, September.

Hu, F. (2015). Do girl peers improve your academic performance? Economics Letters 137, 54-58.

Imberman, S. A. (2011). The effect of charter schools on achievement and behavior of public school students. Journal of Public Economics 95(7-8), 850-863.

Jackson, C. K. (2010). Do students benefit from attending better schools? evidence from rule-based student assignments in trinidad and tobago. The Economic Journal 120(549), 1399-1429.

Jackson, C. K. (2018). What do test scores miss? The importance of teacher effects on non-test score outcomes. Journal of Political Economy 126(5), 2072-2107. 
Jackson, C. K., S. C. Porter, J. Q. Easton, A. Blanchard, and S. Kiguel (2020). School effects on socioemotional development, school-based arrests, and educational attainment. American Economic Review: Insights 2(4), 491-508.

Jacob, B. A. (2002). Where the boys aren't: Non-cognitive skills, returns to school and the gender gap in higher education. Economics of Education review 21(6), 589-598.

Katz, L. F., J. R. Kling, and J. B. Liebman (2001). Moving to opportunity in Boston: Early results of a randomized mobility experiment. The Quarterly Journal of Economics 116(2), 607-654.

Kautz, T., J. J. Heckman, R. Diris, B. Ter Weel, and L. Borghans (2014). Fostering and measuring skills: Improving cognitive and non-cognitive skills to promote lifetime success. National Bureau of Economic Research Working Paper 20749.

Kautz, T. and W. Zanoni (2014). Measuring and fostering non-cognitive skills in adolescence: Evidence from Chicago Public Schools and the OneGoal program. University of chicago chicago working paper.

Larreguy, H. and J. Marshall (2017). The effect of education on civic and political engagement in nonconsolidated democracies: Evidence from Nigeria. Review of Economics and Statistics 99(3), 387-401.

Lavy, V. and A. Schlosser (2011). Mechanisms and impacts of gender peer effects at school. American Economic Journal: Applied Economics 3(2), 1-33.

Lavy, V., O. Silva, and F. Weinhardt (2012). The good, the bad, and the average: Evidence on ability peer effects in schools. Journal of Labor Economics 30(2), 367-414.

Legewie, J. and T. A. DiPrete (2012). School context and the gender gap in educational achievement. American Sociological Review 77(3), 463-485.

Lindgren, K.-O., S. Oskarsson, and M. Persson (2019). Enhancing electoral equality: can education compensate for family background differences in voting participation? American Political Science Review 113(1), 108-122.

Manning, N. and K. Edwards (2014). Does civic education for young people increase political participation? A systematic review. Educational Review 66(1), 22-45.

Martins, P. (2017). (how) do non-cognitive skills programs improve adolescent school achievement? experimental evidence. IZA Discussion Papers 10950.

McDonald, M. P. (2020). Voter turnout demographics. Accessed February 16, 2020. Available at http://www.electproject.org/home/voter-turnout/demographics.

McEachin, A., D. L. Lauen, S. C. Fuller, and R. M. Perera (2020). Social returns to private choice? Effects of charter schools on behavioral outcomes, arrests, and civic participation. Economics of Education Review 76, 101983.

Mettler, S. and M. SoRelle (2014). Policy feedback theory. Theories of the policy process 3, 151-181.

Michener, J. (2018). Fragmented Democracy: Medicaid, Federalism, and Unequal Politics. Cambridge University Press. 
Milligan, K., E. Moretti, and P. Oreopoulos (2004). Does education improve citizenship? Evidence from the United States and the United Kingdom. Journal of Public Economics 88(9-10), 1667-1695.

Nie, N. and D. S. Hillygus (2008). Education and democratic citizenship. In Making Good Citizens: Education and Civil Society., pp. 30-57. Yale University Press.

Nie, N. H., J. Junn, K. Stehlik-Barry, et al. (1996). Education and democratic citizenship in America. University of Chicago Press.

Niemi, R. G. and M. J. Hanmer (2010). Voter turnout among college students: New data and a rethinking of traditional theories. Social Science Quarterly 91(2), 301-323.

Nuamah, S. A. and T. Ogorzalek (2021). Close to home: Place-based mobilization in racialized contexts. American Political Science Review, 1-18.

Oreopoulos, P. and K. G. Salvanes (2011). Priceless: The nonpecuniary benefits of schooling. Journal of Economic Perspectives 25(1), 159-84.

Pelkonen, P. (2012). Length of compulsory education and voter turnout - evidence from a staged reform. Public Choice 150(1-2), 51-75.

Persson, M. (2015). Education and political participation. British Journal of Political Science, 689-703.

Pierson, P. (1993). When effect becomes cause: Policy feedback and political change. World Politics 45(4), 595-628.

Rebell, M. A. (2018). Flunking democracy: Schools, courts, and civic participation. University of Chicago Press.

Reckhow, S., M. Grossmann, and B. C. Evans (2015). Policy cues and ideology in attitudes toward charter schools. Policy Studies Journal 43(2), 207-227.

Rodriguez-Planas, N. (2012). Longer-term impacts of mentoring, educational services, and learning incentives: Evidence from a randomized trial in the united states. American Economic Journal: Applied Economics 4(4), 121-39.

Schattschneider, E. E. et al. (1935). Politics, pressures and the tariff. Prentice-Hall.

Schlozman, K. L., H. E. Brady, and S. Verba (2018). Unequal and unrepresented: Political inequality and the people's voice in the new gilded age. Princeton University Press.

Setren, E. (2021). Targeted vs. general education investments evidence from special education and english language learners in boston charter schools. Journal of Human Resources 56(4), 1073-1112.

Siedler, T. (2010). Schooling and citizenship in a young democracy: Evidence from postwar Germany. Scandinavian Journal of Economics 112(2), 315-338.

Sondheimer, R. M. and D. P. Green (2010). Using experiments to estimate the effects of education on voter turnout. American Journal of Political Science 54(1), 174-189.

Spees, L. P. (2019). Evaluating non-cognitive skills among students switching into and out of charter schools in North Carolina. Journal of School Choice 13(2), 135-157. 
Terrier, C. (2020). Boys lag behind: How teachers' gender biases affect student achievement. Economics of Education Review 77, 101981.

Tuttle, C. C., B. Gill, P. Gleason, V. Knechtel, I. Nichols-Barrer, and A. Resch (2013). KIPP middle schools: Impact on achievement and other outcomes. Technical report. Mathematica Policy Research Report 06441.910.

Unterman, R. (2017). An early look at the effects of Success Academy charter schools. Technical report, MDRC.

Verba, S., K. L. Schlozman, and H. E. Brady (1995). Voice and equality: Civic voluntarism in American politics. Harvard University Press.

Walters, C. R. (2018). The demand for effective charter schools. Journal of Political Economy 126(6).

Wang, C.-H. (2014). Gender differences in the effects of personality traits on voter turnout. Electoral Studies 34, 167-176.

Wantchekon, L., M. Klašnja, and N. Novta (2015). Education and human capital externalities: evidence from colonial Benin. The Quarterly Journal of Economics 130(2), 703-757.

Weinschenk, A. C. and C. T. Dawes (2021). Civic education in high school and voter turnout in adulthood. British Journal of Political Science, 1-15.

West, M. R., M. A. Kraft, A. S. Finn, R. E. Martin, A. L. Duckworth, C. F. Gabrieli, and J. D. Gabrieli (2016). Promise and paradox: Measuring students' non-cognitive skills and the impact of schooling. Educational Evaluation and Policy Analysis 38(1), 148-170.

Winters, M. A. (2020). Charter schools in Newark: The effect on student test scores. Technical report, Manhattan Institute for Policy Research.

Wolfinger, R. E. and S. J. Rosenstone (1980). Who votes? Yale University Press.

Wong, M. D., K. M. Coller, R. N. Dudovitz, D. P. Kennedy, R. Buddin, M. F. Shapiro, S. H. Kataoka, A. F. Brown, C.-H. Tseng, P. Bergman, et al. (2014). Successful schools and risky behaviors among low-income adolescents. Pediatrics 134(2), e389-e396.

Zimmer, R., R. Buddin, S. A. Smith, and D. Duffy (2019). Nearly three decades into the charter school movement, what has research told us about charter schools? Edworkingpaper no. 19-156, Annenberg Institute at Brown University. 


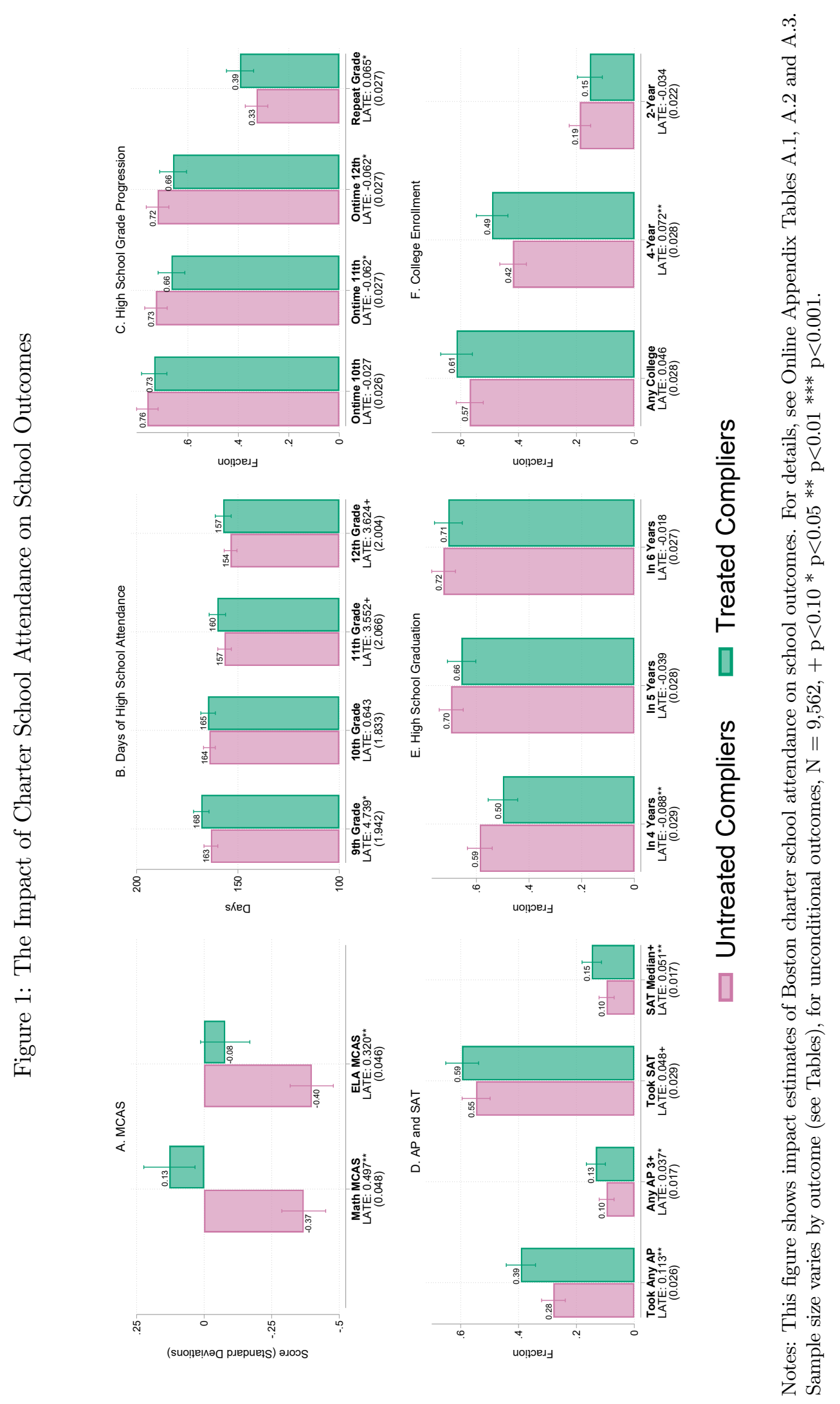


Figure 2: The Impact of Charter School Attendance on Voting
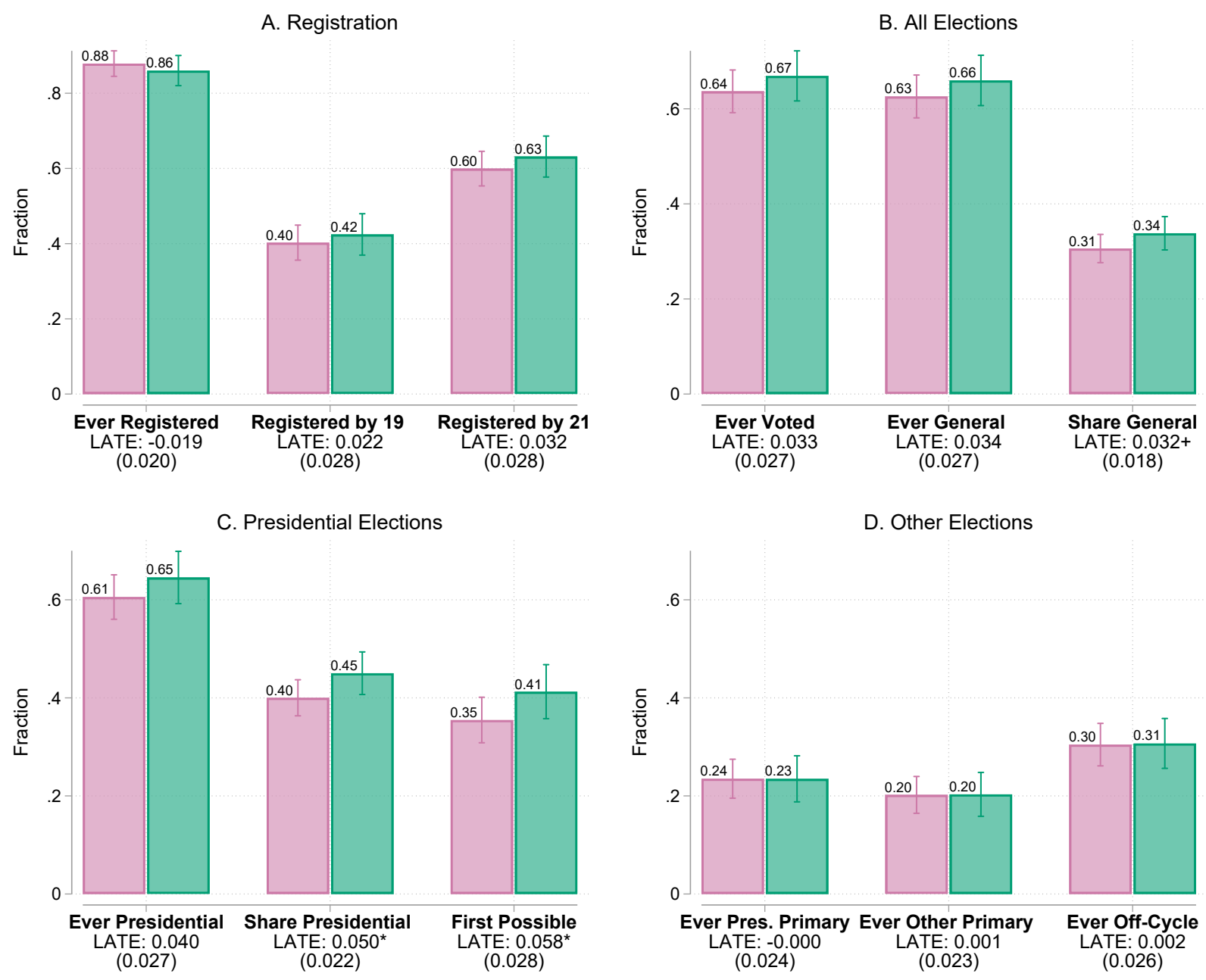

\section{Untreated Compliers}

\section{Treated Compliers}

Notes: This figure shows impact estimates of Boston charter school attendance on voting outcomes. For details, see Online Appendix Tables A.4 and A.5. N $=9,562,+\mathrm{p}<0.10 * \mathrm{p}<0.05 * * \mathrm{p}<0.01 * * * \mathrm{p}<0.001$. 
Figure 3: The Impact of Charter School Attendance on Voting Over Time

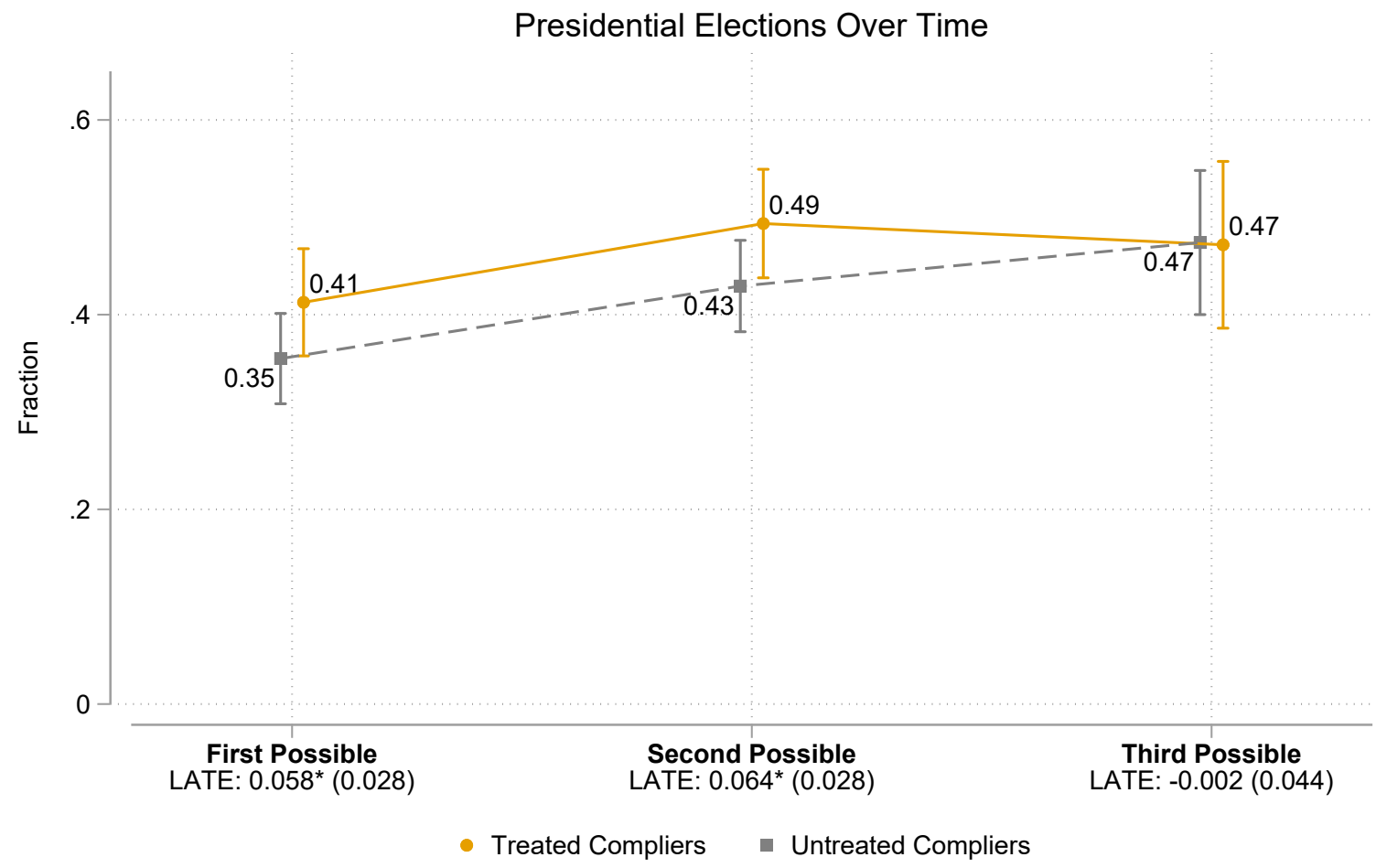

Notes: This figure shows impact estimates of Boston charter school attendance on voting in presidential elections over time. $\mathrm{N}$ (first and second possible presidential elections) $=9,562, \mathrm{~N}$ (third possible presidential election) $=4,671+\mathrm{p}<0.10$ $* \mathrm{p}<0.05 * * \mathrm{p}<0.01 * * * \mathrm{p}<0.001$. 
Figure 4: The Impact of Charter School Attendance on Voting by Subgroups



Notes: This figure shows impact estimates of Boston charter school attendance on voting outcomes for different subgroups of students. $\mathrm{N}$ varies by subgroup. For details, see Online Appendix Table A.6. $+\mathrm{p}<0.10^{*} \mathrm{p}<0.05^{* *} \mathrm{p}<0.01 * * * \mathrm{p}<0.001$. 


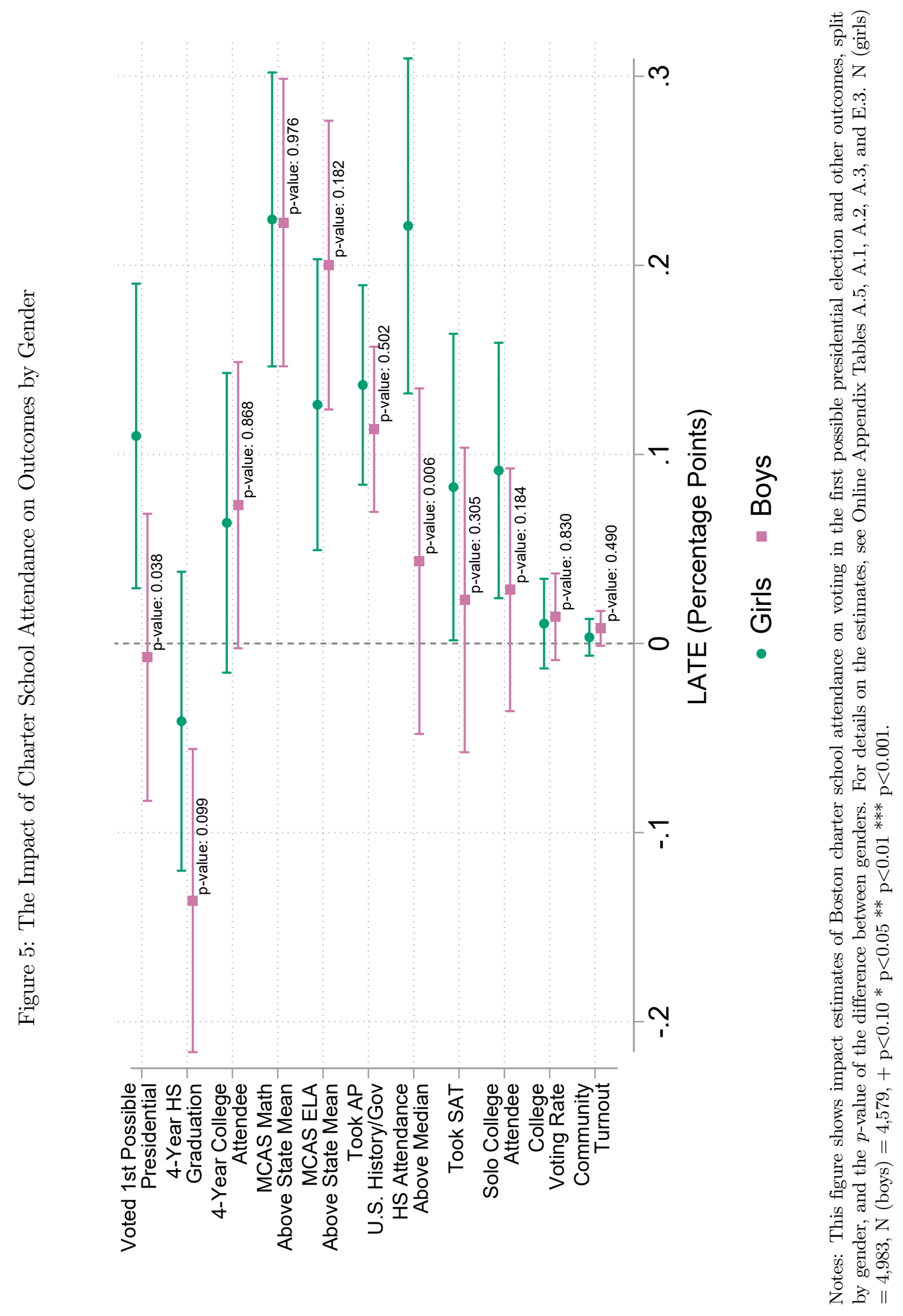


Figure 6: The Impact of Charter School Attendance on Voting by School Mission Statement

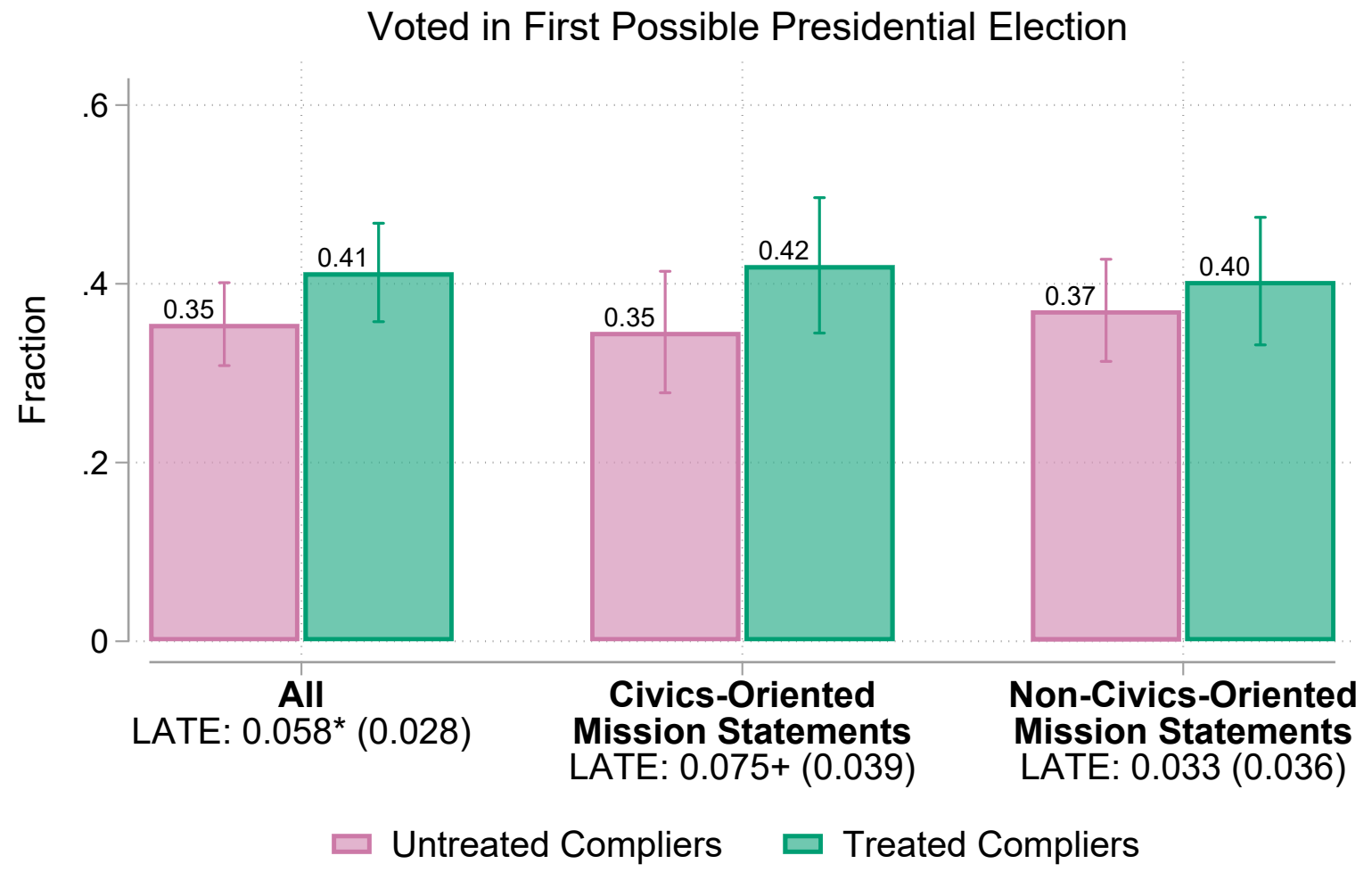

Notes: This figure shows impact estimates of Boston charter school attendance on voting in the first possible presidential election, split by whether or not a charter school's mission statement is "civics-oriented." For details on the estimates, see Online Appendix Table A.7; for differences by gender see Online Appendix Table A.8; for details on the missions statements see Online Appendix Table A.9. $\mathrm{N}=9,562,+\mathrm{p}<0.10 * \mathrm{p}<0.05 * * \mathrm{p}<0.01 * * * \mathrm{p}<0.001$. 
Table 1: Sample Characteristics and Outcomes

\begin{tabular}{|c|c|c|c|c|}
\hline & $\begin{array}{c}\text { Boston } \\
\text { Public Schools } \\
\text { (1) }\end{array}$ & $\begin{array}{c}\text { Lottery } \\
\text { Applicants } \\
\text { (2) }\end{array}$ & $\begin{array}{c}\text { Offered } \\
\text { Charter Seat } \\
(3)\end{array}$ & $\begin{array}{c}\text { Not Offered } \\
\text { Charter Seat } \\
\text { (4) }\end{array}$ \\
\hline \multicolumn{5}{|l|}{ (A) Baseline characteristics } \\
\hline Female & 0.485 & 0.521 & 0.518 & 0.527 \\
\hline Asian & 0.095 & 0.028 & 0.025 & 0.033 \\
\hline Black & 0.417 & 0.585 & 0.597 & 0.560 \\
\hline Latinx & 0.326 & 0.266 & 0.264 & 0.270 \\
\hline Other race & 0.022 & 0.024 & 0.023 & 0.025 \\
\hline White & 0.140 & 0.098 & 0.091 & 0.111 \\
\hline Special education & 0.201 & 0.198 & 0.199 & 0.196 \\
\hline English learner & 0.225 & 0.083 & 0.086 & 0.077 \\
\hline Free/reduced price lunch & 0.751 & 0.738 & 0.743 & 0.727 \\
\hline Baseline MCAS ELA & -0.547 & -0.426 & -0.445 & -0.388 \\
\hline Baseline MCAS Math & -0.440 & -0.383 & -0.397 & -0.355 \\
\hline \multicolumn{5}{|l|}{ (B) Charter school enrollment } \\
\hline Attend any charter in grades 5-12 & 0.065 & 0.421 & 0.511 & 0.243 \\
\hline \multicolumn{5}{|l|}{ (C) Academic outcomes } \\
\hline MCAS Math & -0.315 & -0.220 & -0.166 & -0.329 \\
\hline MCAS ELA & -0.508 & -0.301 & -0.264 & -0.375 \\
\hline Took any AP & 0.290 & 0.288 & 0.295 & 0.274 \\
\hline Score $3+$ on any AP & 0.143 & 0.090 & 0.088 & 0.093 \\
\hline Took SAT & 0.494 & 0.531 & 0.533 & 0.527 \\
\hline SAT score (1600) (for takers) & 915.554 & 864.457 & 866.480 & 860.546 \\
\hline Graduate high school (4 years) & 0.530 & 0.537 & 0.523 & 0.565 \\
\hline Graduate high school (5 years) & 0.618 & 0.639 & 0.629 & 0.661 \\
\hline Enroll in any college & 0.459 & 0.575 & 0.579 & 0.567 \\
\hline Enroll in 4-year college & 0.335 & 0.435 & 0.441 & 0.424 \\
\hline Enroll in 2-year college & 0.144 & 0.172 & 0.170 & 0.177 \\
\hline \multicolumn{5}{|l|}{ (D) Voting outcomes } \\
\hline Ever registered to vote & 0.766 & 0.851 & 0.848 & 0.857 \\
\hline Share presidential & 0.340 & 0.428 & 0.427 & 0.430 \\
\hline Voted in first possible presidential & 0.308 & 0.401 & 0.400 & 0.401 \\
\hline$N$ & 46,956 & 9,562 & 6,360 & 3,202 \\
\hline
\end{tabular}

Notes: This table shows demographic characteristics and outcome means, for various samples. The sample in Column 1 is restricted to students who attended Boston Public Schools in 9th grade in the projected high school classes of 2006 to 2017, who are are least 18 by the 2016 general election. The sample in Column 2 is restricted to charter school applicants enrolled Boston Public Schools or Boston charter schools at the time of application in the projected high school classes of 2006 to 2017 who are at least 18 by the 2016 general election. The samples in Columns 3 and 4 are further restricted to those offered and not offered a seat at a charter in the lottery, respectively. 


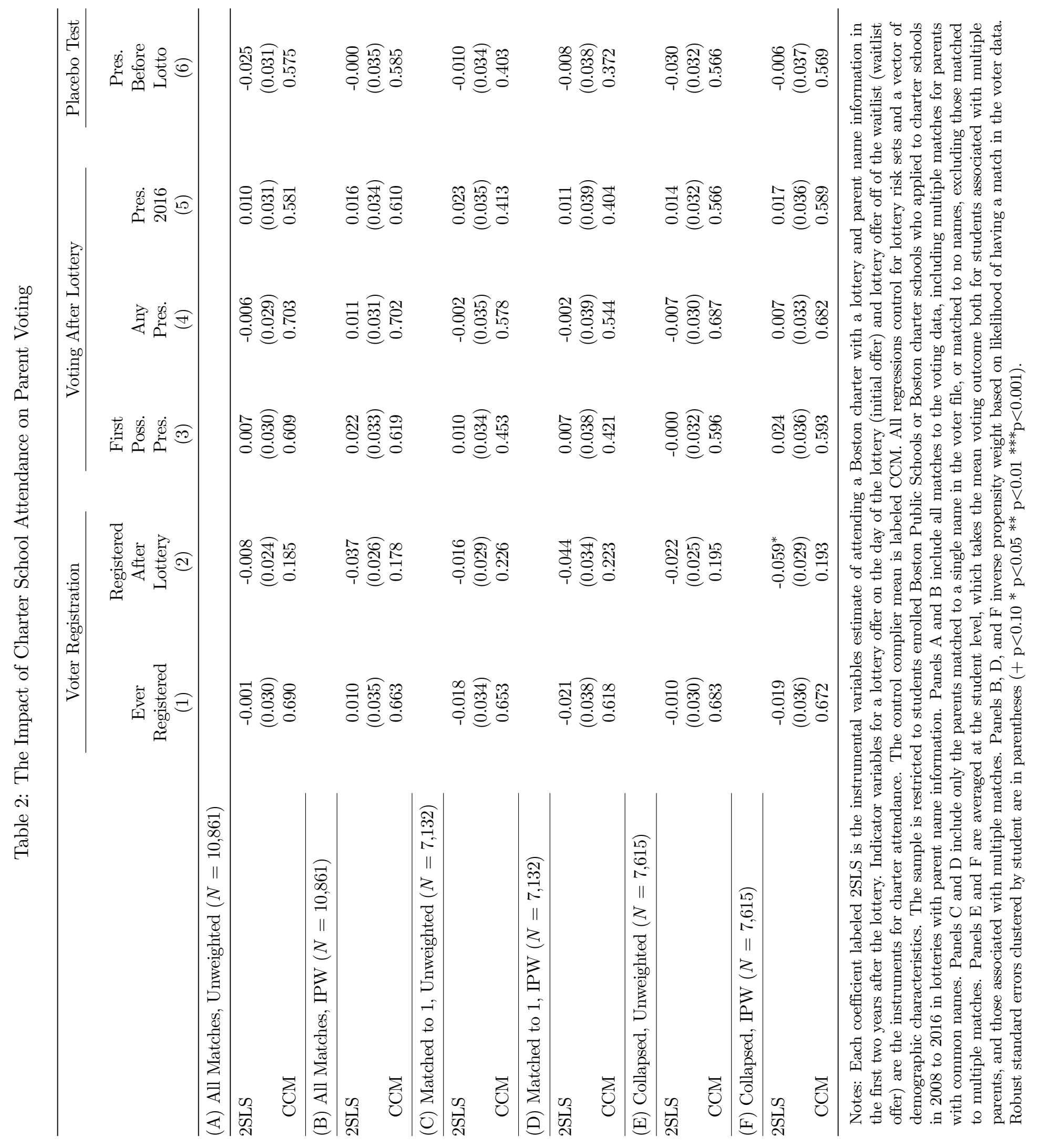




\section{Online Appendix}

\section{Why Does Education Increase Voting?}

Sarah R. Cohodes and James J. Feigenbaum

March 2023 
Appendix A: Detailed Impact Estimates

Online Appendix 1 
Table A.1: The Impact of Charter School Attendance on Days Attended

\begin{tabular}{|c|c|c|c|c|c|}
\hline & $\begin{array}{l}\text { 9th } \\
\text { Grade } \\
(1)\end{array}$ & $\begin{array}{c}10 \text { th } \\
\text { Grade } \\
(2)\end{array}$ & $\begin{array}{c}11 \text { th } \\
\text { Grade } \\
(3)\end{array}$ & $\begin{array}{c}12 \text { th } \\
\text { Grade } \\
(4)\end{array}$ & $\begin{array}{c}\text { All High } \\
\text { School } \\
(5)\end{array}$ \\
\hline \multicolumn{6}{|l|}{ (A) Days Attended } \\
\hline All & $\begin{array}{l}4.739^{*} \\
(1.942)\end{array}$ & $\begin{array}{c}0.643 \\
(1.833)\end{array}$ & $\begin{array}{l}3.552^{+} \\
(2.066)\end{array}$ & $\begin{array}{l}3.624^{+} \\
(2.004)\end{array}$ & $\begin{array}{l}11.934^{*} \\
(4.666)\end{array}$ \\
\hline $\mathrm{CCM}$ & 163.3 & 164.1 & 156.6 & 153.6 & 657.6 \\
\hline$N$ & 8,259 & 7,701 & 7,144 & 7,127 & 6,349 \\
\hline Girls & $\begin{array}{c}9.027^{* * *} \\
(2.725)\end{array}$ & $\begin{array}{c}2.978 \\
(2.473)\end{array}$ & $\begin{array}{l}7.495^{* *} \\
(2.728)\end{array}$ & $\begin{array}{l}6.624^{*} \\
(2.727)\end{array}$ & $\begin{array}{c}21.871^{* * *} \\
(6.219)\end{array}$ \\
\hline $\mathrm{CCM}$ & 160.8 & 162.4 & 154.6 & 151.6 & 648.9 \\
\hline$N$ & 4,302 & 4,062 & 3,805 & 3,844 & 3,452 \\
\hline Boys & $\begin{array}{c}-0.159 \\
(2.794)\end{array}$ & $\begin{array}{l}-1.650 \\
(2.719)\end{array}$ & $\begin{array}{l}-0.594 \\
(3.168)\end{array}$ & $\begin{array}{c}0.903 \\
(3.021)\end{array}$ & $\begin{array}{c}1.550 \\
(7.175)\end{array}$ \\
\hline $\mathrm{CCM}$ & 166.4 & 165.7 & 158.4 & 155.5 & 665.7 \\
\hline$N$ & 3,957 & 3,639 & 3,339 & 3,283 & 2,897 \\
\hline$p$-value & 0.019 & 0.208 & 0.053 & 0.160 & 0.032 \\
\hline \multicolumn{6}{|l|}{ (B) Present in Data } \\
\hline All $(N=9,562)$ & $\begin{array}{c}0.029 \\
(0.019)\end{array}$ & $\begin{array}{c}0.003 \\
(0.023)\end{array}$ & $\begin{array}{l}-0.023 \\
(0.025)\end{array}$ & $\begin{array}{l}-0.026 \\
(0.025)\end{array}$ & $\begin{array}{l}-0.006 \\
(0.027)\end{array}$ \\
\hline $\mathrm{CCM}$ & 0.892 & 0.843 & 0.806 & 0.813 & 0.719 \\
\hline Girls $(N=4,983)$ & $\begin{array}{l}0.050^{+} \\
(0.027)\end{array}$ & $\begin{array}{c}0.043 \\
(0.031)\end{array}$ & $\begin{array}{l}-0.008 \\
(0.035)\end{array}$ & $\begin{array}{c}0.020 \\
(0.034)\end{array}$ & $\begin{array}{c}0.023 \\
(0.037)\end{array}$ \\
\hline $\mathrm{CCM}$ & 0.867 & 0.816 & 0.811 & 0.794 & 0.725 \\
\hline Boys $(N=4,579)$ & $\begin{array}{c}0.011 \\
(0.027)\end{array}$ & $\begin{array}{l}-0.046 \\
(0.033)\end{array}$ & $\begin{array}{l}-0.043 \\
(0.036)\end{array}$ & $\begin{array}{l}-0.079^{*} \\
(0.037)\end{array}$ & $\begin{array}{l}-0.040 \\
(0.040)\end{array}$ \\
\hline $\mathrm{CCM}$ & 0.915 & 0.872 & 0.804 & 0.833 & 0.715 \\
\hline$p$-value & 0.313 & 0.051 & 0.490 & 0.050 & 0.241 \\
\hline
\end{tabular}

Notes: Each coefficient labeled All, Girls, or Boys is the 2SLS instrumental variables estimate of attending a Boston charter with a lottery at any period of time before the outcome listed in the row heading occurred for the full sample, girls, or boys. Indicator variables for a lottery offer on the day of the lottery (initial offer) and lottery offer off of the waitlist (waitlist offer) are the instruments for charter attendance. The control complier mean is labeled CCM. All regressions control for lottery risk sets and a vector of demographic characteristics including indicators for race, birth year, and baseline special education, English learner, and free or reduced price lunch status, all interacted with gender. The sample is restricted to students enrolled Boston Public Schools or Boston charter schools at the time of application in the projected high school classes of 2006 to 2017 who are at least 18 by the 2016 general election. The $p$-value from a test of equality of the girl and boy coefficients is listed in the final row of each panel. Robust standard errors are in parentheses $\left(+\mathrm{p}<0.10^{*} \mathrm{p}<0.05^{* *} \mathrm{p}<0.01^{* * *} \mathrm{p}<0.001\right)$.

Online Appendix 2 


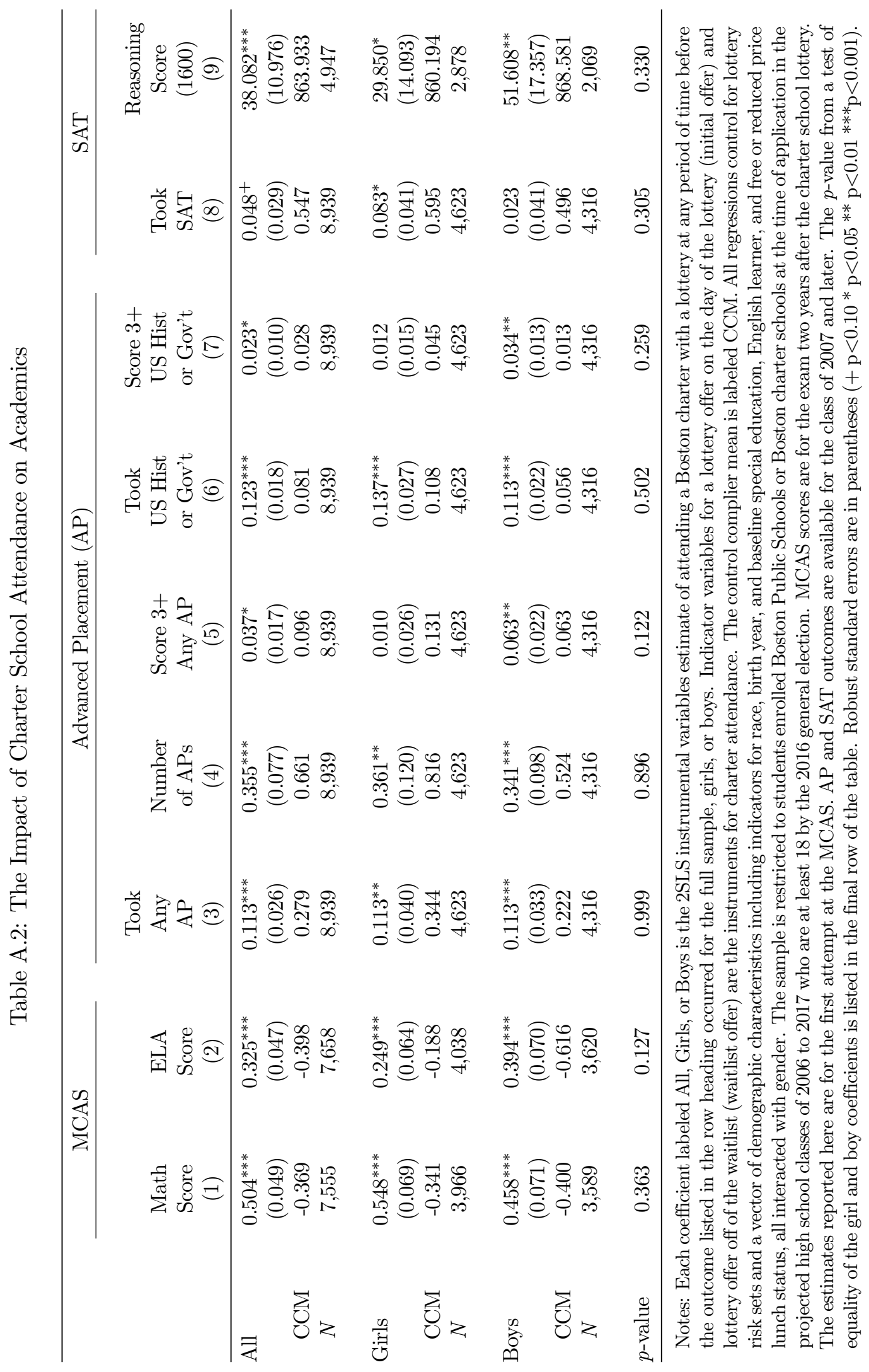

Online Appendix 3 


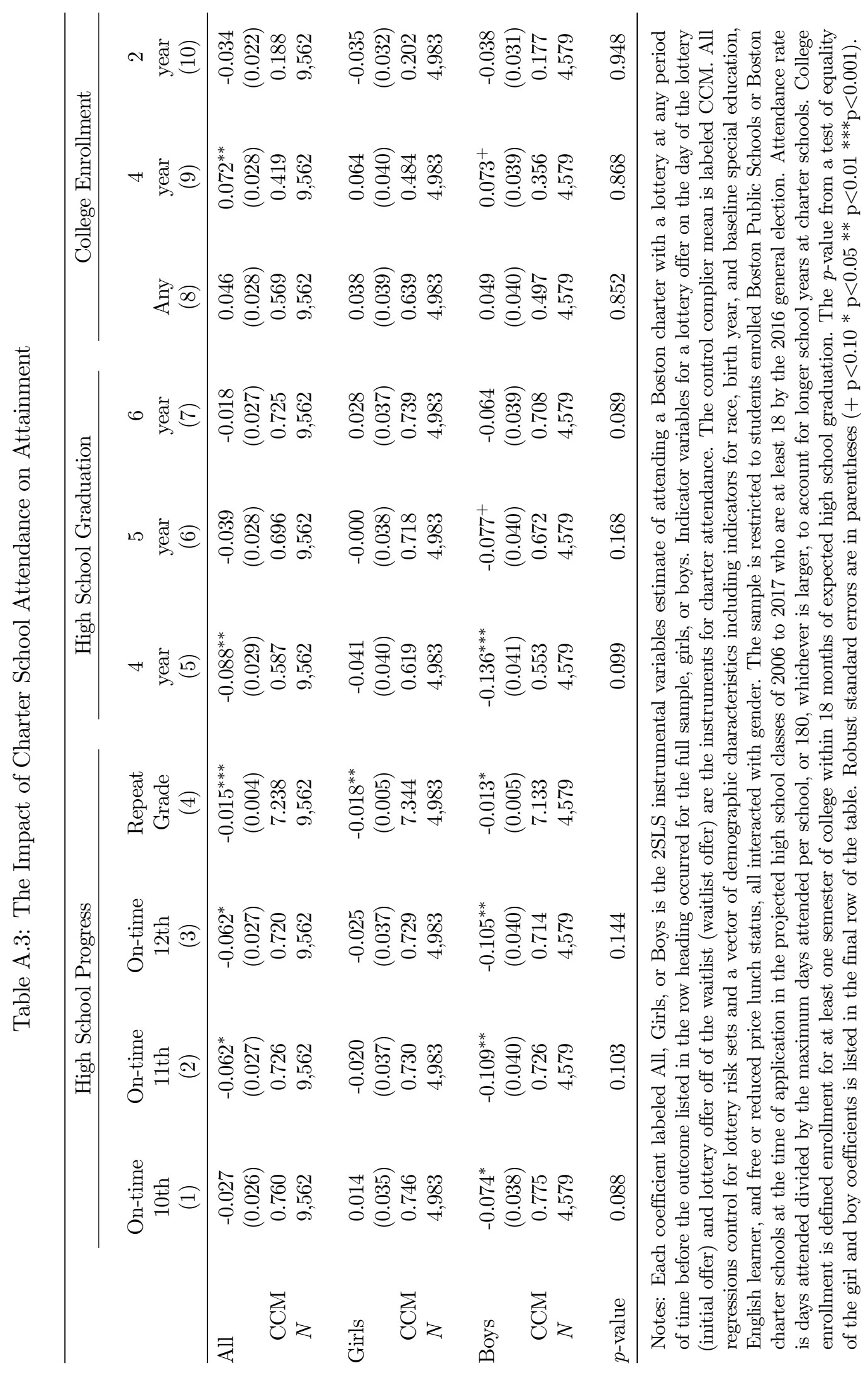

Online Appendix 4 
Table A.4: The Impact of Charter School Attendance on Voting

\begin{tabular}{|c|c|c|c|c|c|c|}
\hline & \multicolumn{3}{|c|}{ Registration } & \multicolumn{3}{|c|}{ All Elections } \\
\hline & $\begin{array}{c}\text { Ever } \\
\text { Registered } \\
(1)\end{array}$ & $\begin{array}{c}\text { Registered } \\
\text { by } 19 \text { th } \\
\text { Birthday } \\
(2)\end{array}$ & $\begin{array}{c}\text { Registered } \\
\text { by } 21 \text { st } \\
\text { Birthday } \\
(3)\end{array}$ & $\begin{array}{l}\text { Ever } \\
\text { Voted } \\
(4)\end{array}$ & $\begin{array}{c}\text { Any } \\
\text { General } \\
\text { Election } \\
\quad(5)\end{array}$ & $\begin{array}{c}\text { Share } \\
\text { General } \\
\text { Elections } \\
(6)\end{array}$ \\
\hline All & $\begin{array}{c}-0.019 \\
(0.020)\end{array}$ & $\begin{array}{c}0.022 \\
(0.028)\end{array}$ & $\begin{array}{c}0.032 \\
(0.028)\end{array}$ & $\begin{array}{c}0.033 \\
(0.027)\end{array}$ & $\begin{array}{c}0.034 \\
(0.027)\end{array}$ & $\begin{array}{l}0.032^{+} \\
(0.018)\end{array}$ \\
\hline CCM & 0.879 & 0.403 & 0.599 & 0.637 & 0.626 & 0.306 \\
\hline$N$ & 9,562 & 9,562 & 9,562 & 9,562 & 9,562 & 9,562 \\
\hline Girls & $\begin{array}{c}-0.034 \\
(0.029)\end{array}$ & $\begin{array}{c}0.021 \\
(0.040)\end{array}$ & $\begin{array}{c}0.013 \\
(0.039)\end{array}$ & $\begin{array}{c}0.032 \\
(0.037)\end{array}$ & $\begin{array}{c}0.033 \\
(0.037)\end{array}$ & $\begin{array}{c}0.024 \\
(0.026)\end{array}$ \\
\hline $\mathrm{CCM}$ & 0.890 & 0.419 & 0.624 & 0.692 & 0.687 & 0.352 \\
\hline$N$ & 4,983 & 4,983 & 4,983 & 4,983 & 4,983 & 4,983 \\
\hline Boys & $\begin{array}{c}-0.003 \\
(0.030)\end{array}$ & $\begin{array}{c}0.004 \\
(0.040)\end{array}$ & $\begin{array}{c}0.047 \\
(0.040)\end{array}$ & $\begin{array}{c}0.023 \\
(0.039)\end{array}$ & $\begin{array}{c}0.023 \\
(0.039)\end{array}$ & $\begin{array}{c}0.029 \\
(0.024)\end{array}$ \\
\hline $\mathrm{CCM}$ & 0.865 & 0.395 & 0.578 & 0.581 & 0.566 & 0.261 \\
\hline$N$ & 4,579 & 4,579 & 4,579 & 4,579 & 4,579 & 4,579 \\
\hline$p$-value & 0.462 & 0.549 & 0.768 & 0.874 & 0.850 & 0.887 \\
\hline
\end{tabular}

Notes: Each coefficient labeled All, Girls, or Boys is the 2SLS instrumental variables estimate of attending a Boston charter with a lottery at any period of time before the outcome listed in the row heading occurred for the full sample, girls, or boys. Indicator variables for a lottery offer on the day of the lottery (initial offer) and lottery offer off of the waitlist (waitlist offer) are the instruments for charter attendance. The control complier mean is labeled CCM. All regressions control for lottery risk sets and a vector of demographic characteristics including indicators for race, birth year, and baseline special education, English learner, and free or reduced price lunch status, all interacted with gender. The sample is restricted to students enrolled Boston Public Schools or Boston charter schools at the time of application in the projected high school classes of 2006 to 2017 who are at least 18 by the 2016 general election. Voting outcomes come from the Massachusetts voter file, supplemented with voting records from nearby states. The $p$-value from a test of equality of the girl and boy coefficients is listed in the final row of the table. Robust standard errors are in parentheses $\left(+\mathrm{p}<0.10^{*} \mathrm{p}<0.05^{* *} \mathrm{p}<0.01 * * * \mathrm{p}<0.001\right)$. 
Table A.5: The Impact of Charter School Attendance on Voting (Continued)

\begin{tabular}{|c|c|c|c|c|c|c|}
\hline & \multicolumn{3}{|c|}{ Presidential Elections } & \multicolumn{3}{|c|}{ Other Elections } \\
\hline & $\begin{array}{c}\text { Ever } \\
\text { Presidential } \\
\text { (1) }\end{array}$ & $\begin{array}{c}\text { Share } \\
\text { Presidential } \\
(2)\end{array}$ & $\begin{array}{c}\text { First } \\
\text { Possible } \\
\text { Presidential } \\
(3)\end{array}$ & $\begin{array}{c}\text { Ever } \\
\text { Presidential } \\
\text { Primary } \\
(4)\end{array}$ & $\begin{array}{c}\text { Ever } \\
\text { Other } \\
\text { Primary } \\
(5)\end{array}$ & $\begin{array}{c}\text { Ever } \\
\text { Off-Cycle } \\
\text { General } \\
(6)\end{array}$ \\
\hline All & $\begin{array}{c}0.040 \\
(0.027)\end{array}$ & $\begin{array}{l}0.050^{*} \\
(0.022)\end{array}$ & $\begin{array}{l}0.058^{*} \\
(0.028)\end{array}$ & $\begin{array}{l}-0.000 \\
(0.024)\end{array}$ & $\begin{array}{c}0.001 \\
(0.023)\end{array}$ & $\begin{array}{c}0.002 \\
(0.026)\end{array}$ \\
\hline $\mathrm{CCM}$ & 0.606 & 0.400 & 0.355 & 0.235 & 0.202 & 0.305 \\
\hline$N$ & 9,562 & 9,562 & 9,562 & 9,562 & 9,562 & 9,562 \\
\hline Girls & $\begin{array}{c}0.035 \\
(0.038)\end{array}$ & $\begin{array}{c}0.042 \\
(0.032)\end{array}$ & $\begin{array}{c}0.110^{* *} \\
(0.041)\end{array}$ & $\begin{array}{l}-0.004 \\
(0.036)\end{array}$ & $\begin{array}{l}-0.003 \\
(0.034)\end{array}$ & $\begin{array}{l}-0.016 \\
(0.039)\end{array}$ \\
\hline $\mathrm{CCM}$ & 0.670 & 0.453 & 0.352 & 0.277 & 0.219 & 0.374 \\
\hline$N$ & 4,983 & 4,983 & 4,983 & 4,983 & 4,983 & 4,983 \\
\hline Boys & $\begin{array}{c}0.034 \\
(0.040)\end{array}$ & $\begin{array}{c}0.044 \\
(0.031)\end{array}$ & $\begin{array}{l}-0.007 \\
(0.039)\end{array}$ & $\begin{array}{c}-0.004 \\
(0.032)\end{array}$ & $\begin{array}{l}-0.005 \\
(0.030)\end{array}$ & $\begin{array}{c}0.007 \\
(0.035)\end{array}$ \\
\hline $\mathrm{CCM}$ & 0.540 & 0.350 & 0.363 & 0.197 & 0.188 & 0.237 \\
\hline$N$ & 4,579 & 4,579 & 4,579 & 4,579 & 4,579 & 4,579 \\
\hline$p$-value & 0.995 & 0.974 & 0.038 & 0.991 & 0.958 & 0.665 \\
\hline
\end{tabular}

Notes: Each coefficient labeled All, Girls, or Boys is the 2SLS instrumental variables estimate of attending a Boston charter with a lottery at any period of time before the outcome listed in the row heading occurred for the full sample, girls, or boys. Indicator variables for a lottery offer on the day of the lottery (initial offer) and lottery offer off of the waitlist (waitlist offer) are the instruments for charter attendance. The control complier mean is labeled CCM. All regressions control for lottery risk sets and a vector of demographic characteristics including indicators for race, birth year, and baseline special education, English learner, and free or reduced price lunch status, all interacted with gender. The sample is restricted to students enrolled Boston Public Schools or Boston charter schools at the time of application in the projected high school classes of 2006 to 2017 who are at least 18 by the 2016 general election. Voting outcomes come from the Massachusetts voter file, supplemented with voting records from nearby states. The elections are general elections in non-presidential years. The $p$-value from a test of equality of the girl and boy coefficients is listed in the final row of the table. Robust standard errors are in parentheses $\left(+\mathrm{p}<0.10^{*} \mathrm{p}<0.05^{* *} \mathrm{p}<0.01{ }^{* * *} \mathrm{p}<0.001\right)$. 


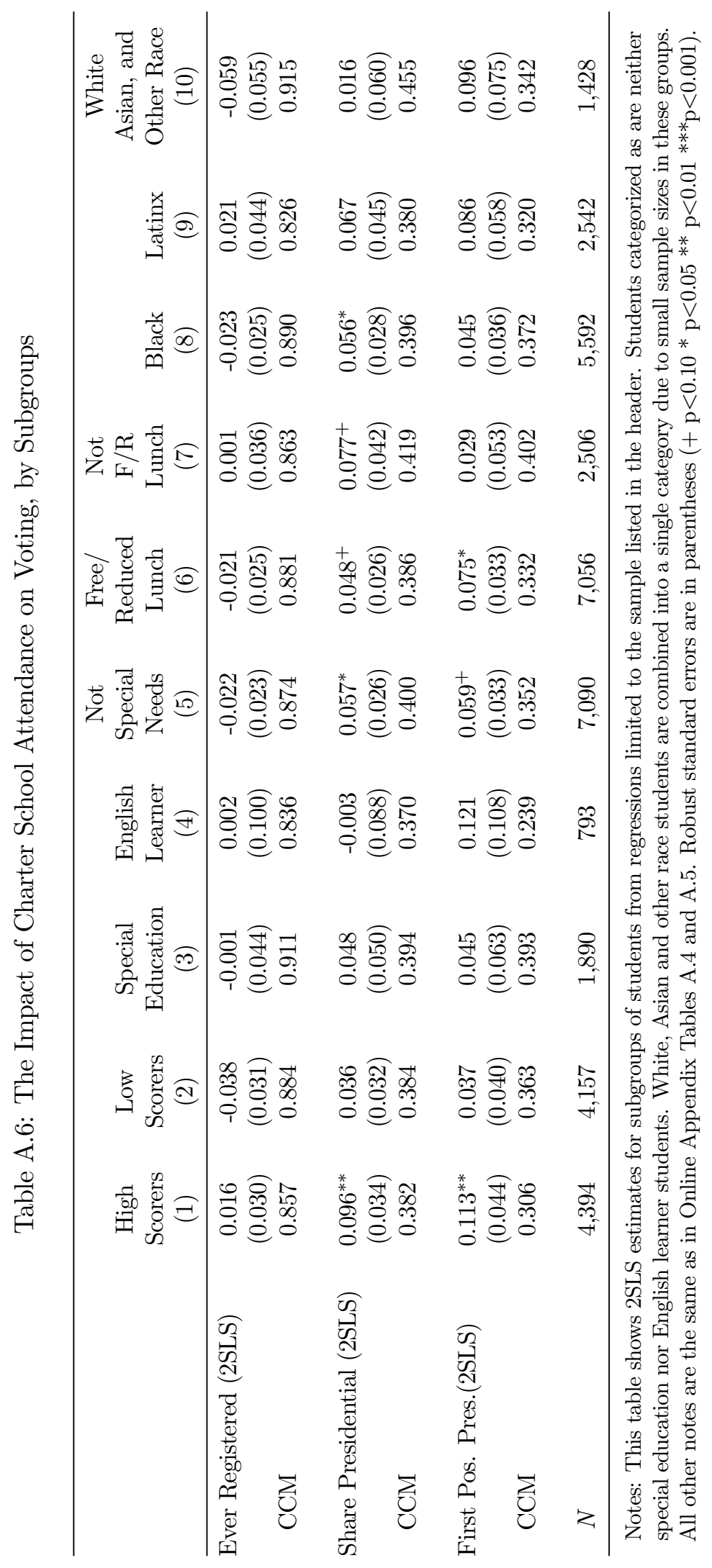

Online Appendix 7 
Table A.7: The Impact of Charter School Attendance on Voting, by Civics-Oriented Charter School Mission Statements

\begin{tabular}{lccc}
\hline & $\begin{array}{c}\text { Ever } \\
\text { Registered } \\
(1)\end{array}$ & $\begin{array}{c}\text { Share } \\
\text { Presidential } \\
(2)\end{array}$ & $\begin{array}{c}\text { Voted in First } \\
\text { Possible Presidential } \\
(3)\end{array}$ \\
\hline Mission Statement with Civics & -0.003 & $0.065^{*}$ & $0.075^{+}$ \\
CCM & $(0.028)$ & $(0.031)$ & $(0.039)$ \\
Mission Statement without Civics & 0.885 & 0.381 & 0.346 \\
CCM & -0.021 & 0.046 & 0.033 \\
\multicolumn{1}{l}{$N$} & $(0.026)$ & $(0.029)$ & $0.036)$ \\
$p$-value & 0.867 & 0.411 & 0.370 \\
\hline
\end{tabular}

Notes: This table shows a modified version of the main specification, in which the endogenous variable and offer variables are accounted for separately for charter schools with mission statements with civics orientations and for those without. All other notes are the same as in Online Appendix Tables A.4 and A.5. See Online Appendix Table A.9 for details on categorization of mission statements. The $p$-value from a test of equality of the civics-oriented and non-civics-oriented coefficients is listed in the final row of the table. Robust standard errors are in parentheses $\left(+\mathrm{p}<0.10^{*} \mathrm{p}<0.05^{* *} \mathrm{p}<0.01 * * * \mathrm{p}<0.001\right)$. 
Table A.8: The Impact of Charter School Attendance on Voting, by Civics-Oriented Charter School Mission Statements and Gender

\begin{tabular}{|c|c|c|c|}
\hline & $\begin{array}{c}\text { Ever } \\
\text { Registered } \\
(1)\end{array}$ & $\begin{array}{c}\text { Share } \\
\text { Presidential } \\
(2)\end{array}$ & $\begin{array}{c}\text { Voted in First } \\
\text { Possible Presidential } \\
(3)\end{array}$ \\
\hline Girls, Mission Statement with Civics & $\begin{array}{l}-0.015 \\
(0.037)\end{array}$ & $\begin{array}{c}0.049 \\
(0.044)\end{array}$ & $\begin{array}{c}0.086 \\
(0.057)\end{array}$ \\
\hline $\mathrm{CCM}$ & 0.909 & 0.457 & 0.380 \\
\hline Boys, Mission Statement with Civics & $\begin{array}{c}0.012 \\
(0.041)\end{array}$ & $\begin{array}{l}0.076^{+} \\
(0.043)\end{array}$ & $\begin{array}{c}0.060 \\
(0.053)\end{array}$ \\
\hline $\mathrm{CCM}$ & 0.856 & 0.294 & 0.304 \\
\hline$p$-value Girls vs. Boys (with Civics) & 0.623 & 0.669 & 0.740 \\
\hline Girls, Mission Statement without Civics & $\begin{array}{c}-0.029 \\
(0.036)\end{array}$ & $\begin{array}{c}0.045 \\
(0.041)\end{array}$ & $\begin{array}{l}0.119^{*} \\
(0.053)\end{array}$ \\
\hline $\mathrm{CCM}$ & 0.909 & 0.457 & 0.380 \\
\hline Boys, Mission Statement without Civics & $\begin{array}{c}-0.013 \\
(0.038)\end{array}$ & $\begin{array}{c}0.036 \\
(0.040)\end{array}$ & $\begin{array}{c}-0.063 \\
(0.051)\end{array}$ \\
\hline $\mathrm{CCM}$ & 0.856 & 0.294 & 0.304 \\
\hline$p$-value Girls vs. Boys (without Civics) & 0.762 & 0.876 & 0.013 \\
\hline$N$ & 9,562 & 9,562 & 9,562 \\
\hline
\end{tabular}

Notes: This table shows a modified version of the main specification, in which the endogenous variable and offer variables are accounted for separately for charter schools with mission statements with civics orientations and for those without. All other notes are the same as in Online Appendix Tables A.4 and A.5. See Online Appendix Table A.9 for details on categorization of mission statements. The $p$-value from a test of equality of the civics-oriented and non-civics-oriented coefficients is listed in the final row of the table. Robust standard errors are in parentheses $\left(+\mathrm{p}<0.10^{*} \mathrm{p}<0.05^{* *} \mathrm{p}<0.01 * * * \mathrm{p}<0.001\right)$. 
Table A.9: Charter School Mission Statements, by Civics-Orientation

\begin{tabular}{ll}
$\begin{array}{l}\text { School } \\
\text { (1) }\end{array}$ & $\begin{array}{l}\text { Mission Statement } \\
(2)\end{array}$ \\
\hline $\begin{array}{l}\text { Academy of } \\
\text { the Pacific }\end{array}$ & $\begin{array}{l}\text { For } 24 \text { years, APR has been committed to serving students of Boston such } \\
\text { that they achieve their full intellectual and social potential, and we now have } \\
\text { Rim }\end{array}$ \\
& $\begin{array}{l}\text { over } 600 \text { alumni. Our work is grounded in the vision that graduates of APR } \\
\text { education because they have mastered college and career ready academic } \\
\text { and social skills, including the knowledge and dispositions to joyfully } \\
\text { pursue future opportunities based on their passions and participate in and } \\
\text { transform civic life. }\end{array}$
\end{tabular}

Boston The mission of Boston Collegiate Charter School is simple yet ambitious: Collegiate

Boston

Green

Academy

Boston

Preparatory

Brooke

Roslindale

City on a Hill

Codman

Academy

Excel

Academy

MATCH

Mission Hill to prepare each student for college.

Boston Green Academy welcomes diverse students of all abilities, educates and empowers them to succeed in college and career, and prepares them to lead in the sustainability of our community and world.

At Boston Prep, we are dedicated to attaining our mission of preparing students to succeed in college and embody lifelong ethical growth. We have carefully designed the Boston Prep program with intention and purpose to provide our students the greatest chance of future success.

Engage together, grow together, achieve together.

City on a Hill graduates responsible, resourceful, and respectful democratic citizens prepared for college and to advance community, culture, and commerce, and to compete in the 21st century. We do so by emphasizing academic achievement, citizenship, teacher leadership, and public accountability.

Our mission is to provide an outstanding, transformative education to prepare students for success in college, further education and beyond.

Excel Academy's mission is to prepare students to succeed in high school and college, apply their learning to solve relevant problems, and engage productively in their communities.

Success in college and beyond for every student.

Roxbury Prep schools are aligned around the " 3 C's" - Curriculum, Character, and Community - that have laid the foundation for Roxbury Prep since its opening.
Civics?

(Reason)

(3)

Yes (civic life)

No

Yes (community)

No

No

Yes (community and citizenship)

No

Yes (community)

No

Yes (community)

Notes: This table lists charter school mission statements and their categorization as civic-oriented, or not. Mission statements were collected from charter school websites in March 2021. For charter schools without explicit mission statements on their website, the main descriptive text about the school was used instead. The mission statements for City on a Hill and MATCH refer to both their campuses, respectively. 
Table A.10: The Impact of Charter School Attendance on College and Community Civic Participation Rates

\begin{tabular}{|c|c|c|c|c|c|}
\hline & $\begin{array}{l}\text { College } \\
\text { Registration } \\
\text { Rate } \\
(1)\end{array}$ & $\begin{array}{c}\text { College } \\
\text { Ever Voting } \\
\text { Rate } \\
(2)\end{array}$ & $\begin{array}{c}\text { College First } \\
\text { Presidential } \\
\text { Rate } \\
(3)\end{array}$ & $\begin{array}{c}\text { County } \\
\text { Registration } \\
\text { Rate } \\
(4)\end{array}$ & $\begin{array}{c}\text { County } \\
\text { Turnout } \\
\text { Rate } \\
(5)\end{array}$ \\
\hline All & $\begin{array}{l}0.013^{+} \\
(0.007)\end{array}$ & $\begin{array}{l}0.023^{*} \\
(0.011)\end{array}$ & $\begin{array}{c}0.014 \\
(0.008)\end{array}$ & $\begin{array}{c}0.004 \\
(0.002)\end{array}$ & $\begin{array}{l}0.006^{+} \\
(0.003)\end{array}$ \\
\hline $\mathrm{CCM}$ & 0.799 & 0.586 & 0.353 & 0.623 & 0.674 \\
\hline$N$ & 9,562 & 9,562 & 9,562 & 9,530 & 9,530 \\
\hline Girls & $\begin{array}{c}0.009 \\
(0.010)\end{array}$ & $\begin{array}{c}0.018 \\
(0.016)\end{array}$ & $\begin{array}{c}0.011 \\
(0.012)\end{array}$ & $\begin{array}{c}0.004 \\
(0.003)\end{array}$ & $\begin{array}{c}0.003 \\
(0.005)\end{array}$ \\
\hline $\mathrm{CCM}$ & 0.822 & 0.625 & 0.381 & 0.626 & 0.680 \\
\hline$N$ & 4,983 & 4,983 & 4,983 & 4,965 & 4,965 \\
\hline Boys & $\begin{array}{c}0.015 \\
(0.010)\end{array}$ & $\begin{array}{c}0.025 \\
(0.016)\end{array}$ & $\begin{array}{c}0.014 \\
(0.012)\end{array}$ & $\begin{array}{c}0.003 \\
(0.003)\end{array}$ & $\begin{array}{l}0.008^{+} \\
(0.005)\end{array}$ \\
\hline $\mathrm{CCM}$ & 0.777 & 0.549 & 0.326 & 0.620 & 0.669 \\
\hline$N$ & 4,579 & 4,579 & 4,579 & 4,565 & 4,565 \\
\hline$p$-value & 0.657 & 0.758 & 0.830 & 0.889 & 0.490 \\
\hline
\end{tabular}

Notes: The outcomes here substitute college or community registration/voting rates for individual voter behavior, with voting rates based on the voting patterns of non-charter Massachusetts students or county level measures (based on college location). All other notes are the same as in Online Appendix Tables A.4 and A.5. The $p$-value from a test of equality of the girl and boy coefficients is listed in the final row of the table. Robust standard errors are in parentheses $(+\mathrm{p}<0.10 * \mathrm{p}<0.05 * * \mathrm{p}<0.01 * * * \mathrm{p}<0.001)$. 


\section{Appendix B: Matching Student Data to the Voter Files}

This Appendix details our procedures for matching student and parent information to the voter files.

\section{Students}

We attempted to match all student records in the SIMS database to the voter files. To increase the likelihood of matching, we included all variations of name and birth dates associated with a student ID in the SIMS database. For example, a student might have one record in the SIMS data with a middle name and one without. The resulting student-level records were then matched with voter records for Massachusetts, using voter files from 2012, 2015, and 2018. We supplemented the Massachusetts voter files with voting records from 2018 for nearby states: Connecticut, Maine, New Hampshire, New York, Rhode Island, and Vermont. ${ }^{46}$

The 2018 voter files also contain a measurement of confidence in voter dates of birth from the vendor. These range from complete date to valid year and month or date to valid year to missing birthdate. These levels of confidence vary by state, as does the presence of date of birth, and thus our matching procedures vary by state. Each of the state voter files is detailed below. The Massachusetts voter file has 4.04 million verified birth dates out of 4.05 million voter records, allowing for the greatest accuracy in the state we are most likely to observe students. Almost all of the records in the Connecticut, New York, and Rhode Island voter files also have verified birth dates, with relatively few missing values for birth dates. In contrast, the New Hampshire voter file is missing roughly 20 percent of voters' birth dates and includes a large number of younger voters who are missing exact birth date. Many birth dates in Maine only include information on year of birth. Finally, the Vermont file has varying levels of birth date information, including some records with complete birth date information and some only containing correct year or correct year and month.

Online Appendix Table B.1 details the rate at which students in the lottery sample, and Massachusetts as a whole, appear in the voter files for any of these states, by the state of the college they attended (or in a line for no college). We count students for each state they are registered in, so a student may appear in more than one state. We see that students are most likely to be registered in Massachusetts, no matter the state of the college that they attend, and that many students who attend college out of state remain registered solely in Massachusetts. College state and state of registration align closely, which is a check that matches outside of Massachusetts are likely good ones.

To begin our matching procedures, we searched for exact matches between the SIMS and voter information on first name, last name, and date of birth in the Massachusetts voter records. Students matched in this way were declared as matches and set aside. We then employed fuzzy matching techniques to account for minor discrepancies in identifying information between the two data sources for the remaining students. We make use of two string distance metrics. The first is Jaro-Winkler Distance (JWD) which ranges from 0 to 1 , with 0 meaning an exact match, measures edits to convert one string to another with more weight (penalty) for discrepancies early in the string. The second is Cosine String Distance which yields the distance between q-gram profiles of strings; for example, cosine distance with $q=4$ depends on how many 4-letter sequences two strings share. Cosine distances with larger values of $q$ are particularly good at matching students with hyphenated last names which are often transposed in different sources. We also use Soundex encoding. Based on careful review of the voter files and the student data, we developed several variants of fuzzy matching:

1. Require exact matches on first name and last name; require two of birth day, birth month, and birth year to match; require birth year to be off by no more than two years; require middle initial

\footnotetext{
${ }^{46}$ The New England states have a tuition-compact where regional students do not have to pay full out-of-state tuition rates at public colleges and universities. For details, see: https://nebhe.org/tuitionbreak/.
}

Online Appendix 12 
to match; if a middle name is reported in both sources (relatively rare), require middle name to be within 0.1 in JWD.

2. Require exact matches on first name and date of birth; require last names to be within 0.2 in JWD or 0.2 in cosine distance with $q=1$; require last names to be within 0.5 in cosine distance with $q=3$.

3. Require exact matches on last name and date of birth; require first names to be within 0.2 in JWD or 0.2 in cosine distance with $q=1$; require first names to be less than 1 in cosine distance with $q=4$ or agree on soundex code or within 0.2 in JWD.

4. Require exact matches on birthdate; require first name to be within 0.2 in JWD; require last name to be within 0.2 in JWD; require last names to be less than 1 in cosine distance with $q=4$ or the sum of JWD in first and last name to be less than 0.15 ; require gender to match.

5. Require exact matches in last name and date of birth; require first name to match middle name from SIMS to voter file or from voter file to SIMS; require first letter of first name to match first letter of middle name (in both directions). This captures students reversing first and middle names between SIMS and the voter file.

6. Require exact matches in first and last name; require year of birth to match; require day of birth to match month of birth (in both directions). This captures students reversing their day and month of birth.

We then supplemented the Massachusetts records with voter files from neighboring states. We attempt to match all students, including those matched above to the Massachusetts voter file, to recover voting history for students who move out of state whether or not they have previously registered to vote in Massachusetts. Due to the state-level variance in the date of birth confidence levels (especially out of Massachusetts) and to ensure that we are matching a student record to the correct voter record, we employ four rounds of matching with different stipulations. In the first round of matching, students are matched with voter records based on exact matches in first name, last name, and birth date. Again, these matches are set aside before we employ fuzzy matching (with more restrictions than in our matching within Massachusetts because we know, in general, that the students in our sample are mostly likely to be in MA). In the second round, we focus on records in the voter file with only a valid year and month or day of birth. We match exactly on first name, last name, and gender, require middle initial to match, and require birth year and birth month to match, and if a middle name is reported in both sources (relatively rare), require middle name to be within 0.1 in JWD. In the third round, we focus on records in the voter file with only a valid year. We match exactly on first name, last name, and gender, require middle initial to match, and require birth year to match, and if a middle name is reported in both sources (relatively rare), require middle name to be within 0.1 in JWD. In the fourth round, we focus on records in the voter file with a missing birth date and students in SIMS who are the only student with their exact first and last name in SIMS. We match exactly on first name, last name, and gender, require middle initial to match, and if a middle name is reported in both sources (relatively rare), require middle name to be within 0.1 in JWD.

\section{Parents}

Some charter schools that provided us with the charter lottery data also provided us with parent information for the students. We include charter school lotteries where over 90 percent of the student entries included parent information. This includes the following charter school lotteries: Academy of the Pacific Rim (2011, 2012, 2013); Boston Collegiate (2009); Boston Preparatory (2005, 2007, 2010, 
2012, 2013); City on a Hill (2005, 2006, 2007, 2008, 2009, 2010, 2011, 2012); Codman Academy (2008, 2010, 2011); and Roxbury Prep (2002, 2003, 2004, 2005, 2009, 2011). This resulted in a sample of 8,302 parents, representing 6,388 students (since students can have two parent/guardians in the lottery records). Restricting this to students who met sample criteria (baseline covariates present and Boston residents at baseline) reduced the sample to 5,845 students with 7,635 parents.

To match the parent records with their respective voter records, we employed a similar technique as described for the student matching. In this case, parent information from the charter school lotteries is sparse. To address this, we only matched parents with Massachusetts voter records for individuals residing in a Boston zip code to reduce the likelihood of a false match; we further require parents to be between 14 and 60 years old when their charter lottery child was born to filter out implausible matches. We use Jaro-Winkler distance matching to create a measurement of similarity between parent names and voter names. To allow for normal variation in name formats (hyphenated names, multiple last names, misspellings, etc.), we consider records with both first and last names with JWD scores of 0.1 or lower as an accurate match. This produces 18,258 potential-parent-voter records for analysis, since many parents are matched to multiple voter records. Because we do not have an additional piece of information, like date of birth, for parents, we cannot distinguish which voter record is the correct one when a parent name matches to multiple voter records. We thus retain all potential methods and estimate several models that account for parent matches in different ways, as discussed in the main text. 


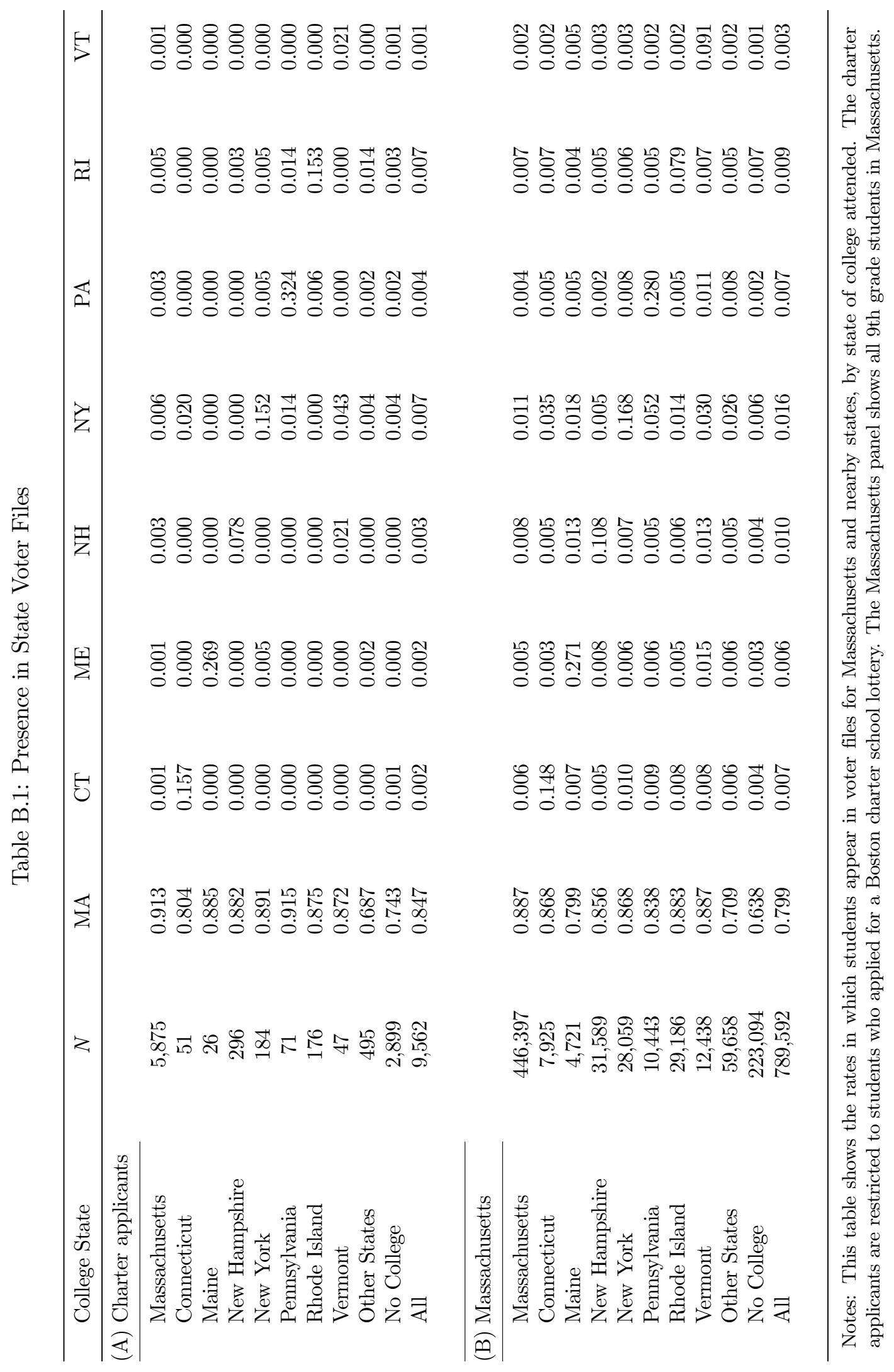

Online Appendix 15 
Appendix C: Charter Lottery Details

Online Appendix 16 


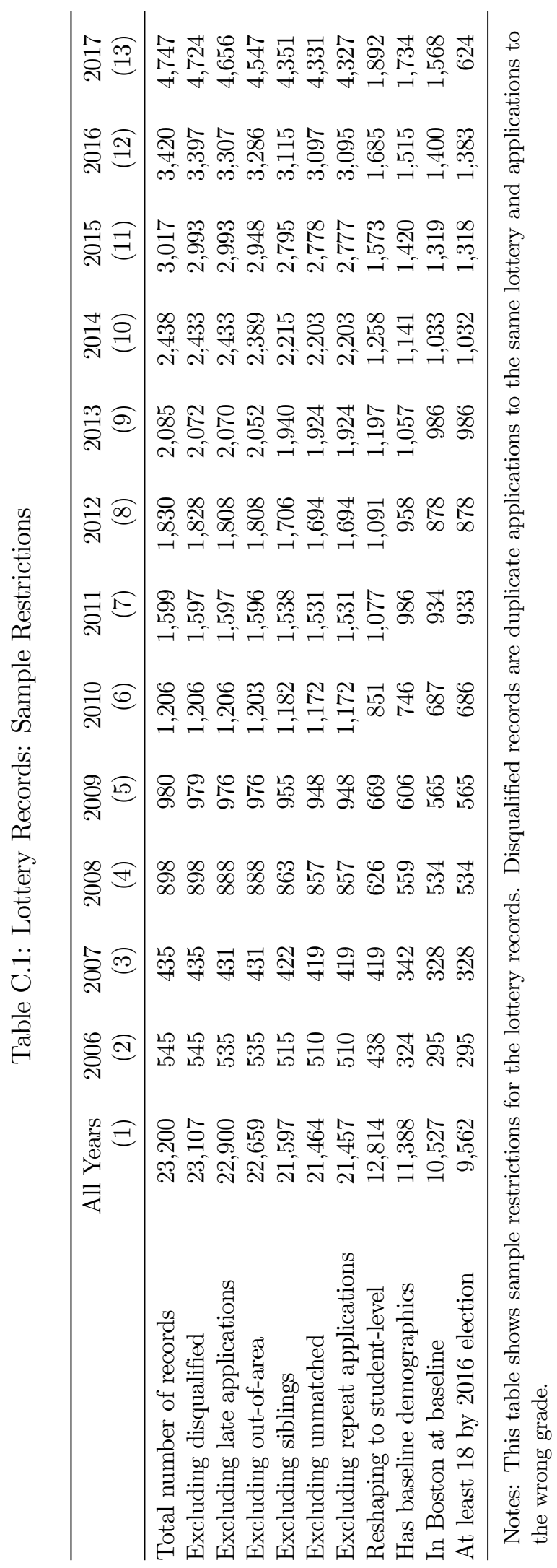

Online Appendix 17 




Online Appendix 18 
Table C.3: Covariate Balance

\begin{tabular}{|c|c|c|c|}
\hline & $\begin{array}{c}\text { Non-offered } \\
\text { Mean } \\
(1)\end{array}$ & $\begin{array}{l}\text { Initial Offer } \\
\text { Differential } \\
\text { (2) }\end{array}$ & $\begin{array}{c}\text { Waitlist Offer } \\
\text { Differential } \\
(3)\end{array}$ \\
\hline Female & 0.527 & $\begin{array}{l}-0.000 \\
(0.012)\end{array}$ & $\begin{array}{c}0.001 \\
(0.012)\end{array}$ \\
\hline Asian & 0.032 & $\begin{array}{c}-0.003 \\
(0.004)\end{array}$ & $\begin{array}{c}0.002 \\
(0.004)\end{array}$ \\
\hline Black & 0.564 & $\begin{array}{c}0.007 \\
(0.012)\end{array}$ & $\begin{array}{c}-0.003 \\
(0.012)\end{array}$ \\
\hline Latinx & 0.273 & $\begin{array}{c}-0.006 \\
(0.011)\end{array}$ & $\begin{array}{c}0.003 \\
(0.011)\end{array}$ \\
\hline Other race & 0.024 & $\begin{array}{c}0.003 \\
(0.004)\end{array}$ & $\begin{array}{r}-0.007+ \\
(0.004)\end{array}$ \\
\hline White & 0.107 & $\begin{array}{c}-0.000 \\
(0.007)\end{array}$ & $\begin{array}{c}0.005 \\
(0.007)\end{array}$ \\
\hline Special education & 0.196 & $\begin{array}{c}0.002 \\
(0.010)\end{array}$ & $\begin{array}{c}-0.013 \\
(0.010)\end{array}$ \\
\hline English learner & 0.076 & $\begin{array}{c}-0.009 \\
(0.007)\end{array}$ & $\begin{array}{c}0.012+ \\
(0.007)\end{array}$ \\
\hline Free/reduced price lunch & 0.732 & $\begin{array}{c}0.004 \\
(0.010)\end{array}$ & $\begin{array}{c}-0.003 \\
(0.011)\end{array}$ \\
\hline Baseline MCAS ELA & -0.404 & $\begin{array}{c}-0.036 \\
(0.025)\end{array}$ & $\begin{array}{c}0.033 \\
(0.025)\end{array}$ \\
\hline \multirow[t]{2}{*}{ Baseline MCAS Math } & -0.371 & $\begin{array}{c}-0.038 \\
(0.023)\end{array}$ & $\begin{array}{c}0.036 \\
(0.024)\end{array}$ \\
\hline & $p$-value & 0.718 & 0.407 \\
\hline
\end{tabular}

Notes: This table shows means and offer differentials for baseline characteristics. The sample is restricted to students enrolled Boston Public Schools or Boston charter schools at the time of application in the projected high school classes of 2006 to 2017 who are at least 18 by the 2016 general election. Column 1 shows the proportion of non-offered students with a given characteristic. Columns 2 and 3 report coefficients from regressions of the student characteristic on initial and waitlist offer dummies, including controls for risk sets, application grade, an $(+\mathrm{p}<0.10 * \mathrm{p}<0.05 * * \mathrm{p}<0.01$ $\left.{ }^{* * *} \mathrm{p}<0.001\right)$. The $\mathrm{p}$-values are from tests of the hypothesis that all coefficients on each offer are zero. $N=9,562$. 
Table C.4: The Impact of Charter School Attendance on Predicted Voting

\begin{tabular}{|c|c|c|c|}
\hline & $\begin{array}{c}\text { Ever } \\
\text { Registered } \\
(1)\end{array}$ & $\begin{array}{c}\text { Share } \\
\text { Presidential } \\
(2)\end{array}$ & $\begin{array}{c}\text { First Possible } \\
\text { Presidential } \\
(3)\end{array}$ \\
\hline All & $\begin{array}{c}-0.004 \\
(0.004)\end{array}$ & $\begin{array}{c}-0.005 \\
(0.005)\end{array}$ & $\begin{array}{c}-0.005 \\
(0.004)\end{array}$ \\
\hline $\mathrm{CCM}$ & 0.840 & 0.395 & 0.373 \\
\hline$N$ & 9,562 & 9,562 & 9,562 \\
\hline Girls & $\begin{array}{c}0.002 \\
(0.005)\end{array}$ & $\begin{array}{c}-0.002 \\
(0.006)\end{array}$ & $\begin{array}{c}-0.001 \\
(0.006)\end{array}$ \\
\hline $\mathrm{CCM}$ & 0.862 & 0.460 & 0.433 \\
\hline$N$ & 4,983 & 4,983 & 4,983 \\
\hline Boys & $\begin{array}{c}-0.010^{+} \\
(0.006)\end{array}$ & $\begin{array}{c}-0.009 \\
(0.006)\end{array}$ & $\begin{array}{c}-0.009 \\
(0.005)\end{array}$ \\
\hline CCM & 0.817 & 0.327 & 0.311 \\
\hline$N$ & 4,579 & 4,579 & 4,579 \\
\hline$p$-value & 0.114 & 0.421 & 0.322 \\
\hline
\end{tabular}

Notes: Each coefficient labeled All, Girls, or Boys is the 2SLS instrumental variables estimate of attending a Boston charter with a lottery at any period of time before the outcome listed in the row heading occurred for the full sample, girls, or boys. Indicator variables for a lottery offer on the day of the lottery (initial offer) and lottery offer off of the waitlist (waitlist offer) are the instruments for charter attendance. The control complier mean is labeled CCM. All regressions control for lottery risk sets and a vector of demographic characteristics including indicators for race, birth year, and baseline special education, English learner, and free or reduced price lunch status, all interacted with gender. The sample is restricted to students enrolled Boston Public Schools or Boston charter schools at the time of application in the projected high school classes of 2006 to 2017 who are at least 18 by the 2016 general election. Predicted voting likelihoods are calculated in the non-charter BPS sample using demographics and baseline test scores, with predicted values applied to the charter lottery population. The $p$-value from a test of equality of the girl and boy coefficients is listed in the final row of the table. Robust standard errors are in parentheses $\left(+\mathrm{p}<0.10^{*} \mathrm{p}<0.05^{* *} \mathrm{p}<0.01 * * * \mathrm{p}<0.001\right)$. 
Table C.5: Match Rate to SIMS

\begin{tabular}{|c|c|c|c|c|}
\hline Projected HS Class & $\begin{array}{l}\text { Non-offered } \\
\text { Mean } \\
(1)\end{array}$ & $\begin{array}{c}\text { Initial Offer } \\
\text { Differential } \\
\text { (2) }\end{array}$ & $\begin{array}{c}\text { Waitlist Offer } \\
\text { Differential } \\
(3)\end{array}$ & $\begin{array}{c}\text { Number of } \\
\text { Applications } \\
\text { (4) }\end{array}$ \\
\hline 2006 & 0.986 & $\begin{array}{c}-0.008 \\
(0.012)\end{array}$ & $\begin{array}{c}0.008 \\
(0.009)\end{array}$ & 515 \\
\hline 2007 & 0.997 & $\begin{array}{c}-0.011 \\
(0.017)\end{array}$ & $\begin{array}{c}-0.033 \\
(0.038)\end{array}$ & 422 \\
\hline 2008 & 0.996 & $\begin{array}{c}-0.015 \\
(0.011)\end{array}$ & $\begin{array}{c}0.008 \\
(0.009)\end{array}$ & 863 \\
\hline 2009 & 0.994 & $\begin{array}{c}-0.001 \\
(0.008)\end{array}$ & $\begin{array}{c}-0.002 \\
(0.008)\end{array}$ & 955 \\
\hline 2010 & 0.994 & $\begin{array}{c}-0.001 \\
(0.009)\end{array}$ & $\begin{array}{c}-0.001 \\
(0.009)\end{array}$ & 1,182 \\
\hline 2011 & 0.996 & $\begin{array}{l}-0.000 \\
(0.005)\end{array}$ & $\begin{array}{c}0.002 \\
(0.007)\end{array}$ & 1,538 \\
\hline 2012 & 0.992 & $\begin{array}{c}-0.001 \\
(0.005)\end{array}$ & $\begin{array}{c}0.000 \\
(0.005)\end{array}$ & 1,706 \\
\hline 2013 & 0.993 & $\begin{array}{c}-0.004 \\
(0.006)\end{array}$ & $\begin{array}{c}0.003 \\
(0.005)\end{array}$ & 1,940 \\
\hline 2014 & 0.994 & $\begin{array}{c}0.000 \\
(0.005)\end{array}$ & $\begin{array}{c}0.003 \\
(0.004)\end{array}$ & 2,215 \\
\hline 2015 & 0.996 & $\begin{array}{c}-0.001 \\
(0.005)\end{array}$ & $\begin{array}{c}-0.001 \\
(0.003)\end{array}$ & 2,795 \\
\hline 2016 & 0.994 & $\begin{array}{c}-0.001 \\
(0.004)\end{array}$ & $\begin{array}{c}0.001 \\
(0.004)\end{array}$ & 3,115 \\
\hline 2017 & 0.995 & $\begin{array}{c}-0.003 \\
(0.003)\end{array}$ & $\begin{array}{c}0.002 \\
(0.003)\end{array}$ & 4,351 \\
\hline All cohorts & 0.995 & $\begin{array}{c}-0.003^{*} \\
(0.002)\end{array}$ & $\begin{array}{c}0.000 \\
(0.001)\end{array}$ & 21,597 \\
\hline
\end{tabular}

Notes: This table shows the match between lottery records and the SIMS data by projected high school class. The sample excludes disqualified, late, out-of-area, and sibling applications. It includes students who are under the age of 18 at the time of the 2016 election since birth date is only available for students who match to the SIMS data. Individuals can be in the sample multiple times if they apply to multiple schools. Columns 2 and 3 report coefficients from regressions of the student characteristic on initial and waitlist offer dummies, including controls for risk sets $(+$ $\left.\mathrm{p}<0.10^{*} \mathrm{p}<0.05^{* *} \mathrm{p}<0.01 * * * \mathrm{p}<0.001\right)$. 
Table C.6: Attrition

\begin{tabular}{lccc}
\hline & $\begin{array}{c}\text { Fraction of Non- } \\
\text { Offered With Outcome } \\
\end{array}$ & $\begin{array}{c}\text { Initial Offer } \\
\text { Differential } \\
(1)\end{array}$ & $\begin{array}{c}\text { Waitlist Offer } \\
\text { Differential } \\
(3)\end{array}$ \\
\hline Has ELA score (2 years after lottery) & 0.803 & 0.006 & 0.015 \\
Has math score (2 years after lottery) & 0.785 & $(0.009)$ & $(0.010)$ \\
& & 0.008 & 0.012 \\
Present in 12th grade in data & 0.754 & $(0.009)$ & $(0.010)$ \\
& & -0.004 & -0.009 \\
Sent to NSC & 0.978 & $(0.011)$ & $(0.011)$ \\
& & 0.001 & -0.000 \\
& & $(0.004)$ & $(0.003)$ \\
\hline
\end{tabular}

Notes: This table shows follow-up rates for MCAS scores two years after charter application, presence in the data in 12th grade, and an indicator for being sent to the NSC to be matched to college outcome data for Boston charter school applicants. The sample is restricted to students enrolled Boston Public Schools or Boston charter schools at the time of application in the projected high school classes of 2006 to 2017 who are at least 18 by the 2016 general election. Column 1 shows the proportion of non-offered students with a given outcome. Columns 2 and 3 report coefficients from regressions of the student characteristic on initial and waitlist offer dummies, including controls for risk sets $(+$ $\mathrm{p}<0.10 * \mathrm{p}<0.05 * * \mathrm{p}<0.01 * * * \mathrm{p}<0.001) . \quad N=9,562$. 
Table C.7: The Impact of Charter School Offers on Charter Attendance

\begin{tabular}{|c|c|c|c|}
\hline & $\begin{array}{c}\text { Non-offered } \\
\text { Mean } \\
(1)\end{array}$ & $\begin{array}{l}\text { Initial } \\
\text { Offer } \\
(2) \\
\end{array}$ & $\begin{array}{c}\text { Waitlist } \\
\text { Offer } \\
(3)\end{array}$ \\
\hline \multicolumn{4}{|l|}{ (A) Ever attend charter } \\
\hline All & 0.072 & $\begin{array}{c}0.460^{* * *} \\
(0.011)\end{array}$ & $\begin{array}{c}0.301^{* * *} \\
(0.011)\end{array}$ \\
\hline Girls & 0.072 & $\begin{array}{c}0.440 * * * \\
(0.015)\end{array}$ & $\begin{array}{c}0.304^{* * *} \\
(0.015)\end{array}$ \\
\hline Boys & 0.073 & $\begin{array}{c}0.483^{* * *} \\
(0.016)\end{array}$ & $\begin{array}{c}0.299^{* * *} \\
(0.016)\end{array}$ \\
\hline \multicolumn{4}{|l|}{ (B) Years attended charter } \\
\hline All & 0.557 & $\begin{array}{c}1.555^{* * *} \\
(0.055)\end{array}$ & $\begin{array}{c}1.008^{* * *} \\
(0.052)\end{array}$ \\
\hline Girls & 0.549 & $\begin{array}{c}1.572^{* * *} \\
(0.074)\end{array}$ & $\begin{array}{c}1.055^{* * *} \\
(0.071)\end{array}$ \\
\hline Boys & 0.566 & $\begin{array}{c}1.534^{* * *} \\
(0.083)\end{array}$ & $\begin{array}{c}0.957^{* * *} \\
(0.076)\end{array}$ \\
\hline
\end{tabular}

Notes: This table shows the impact of a charter school offer on charter school attendance for the full sample, girls, and boys. The sample is restricted to students enrolled Boston Public Schools or Boston charter schools at the time of application in the projected high school classes of 2006 to 2017 who are at least 18 by the 2016 general election. Column 1 shows the proportion of non-offered students with a given characteristic. Columns 2 and 3 report coefficients from regressions of charter attendance on initial and waitlist offer dummies, including controls for demographic characteristics and risk sets. Robust standard errors are in parentheses $(+\mathrm{p}<0.10 * \mathrm{p}<0.05 * * \mathrm{p}<0.01 * * * \mathrm{p}<0.001) . N=9,562$.

Online Appendix 23 
Appendix D: Robustness Checks

Online Appendix 24 
Figure D.1: Voting Impacts Omitting Cohorts

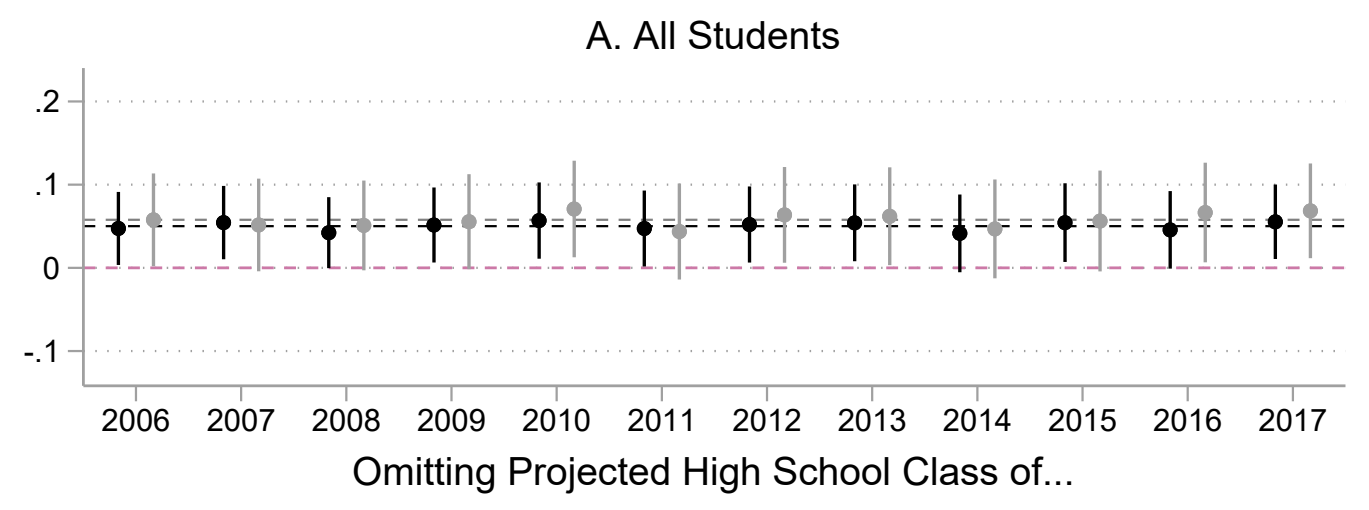

B. Girls

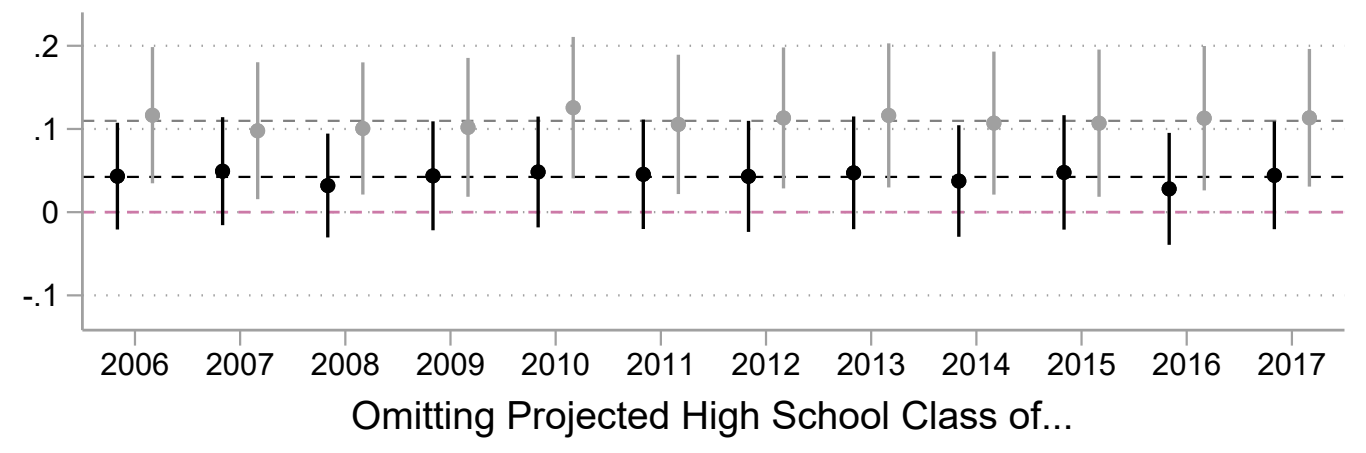

C. Boys

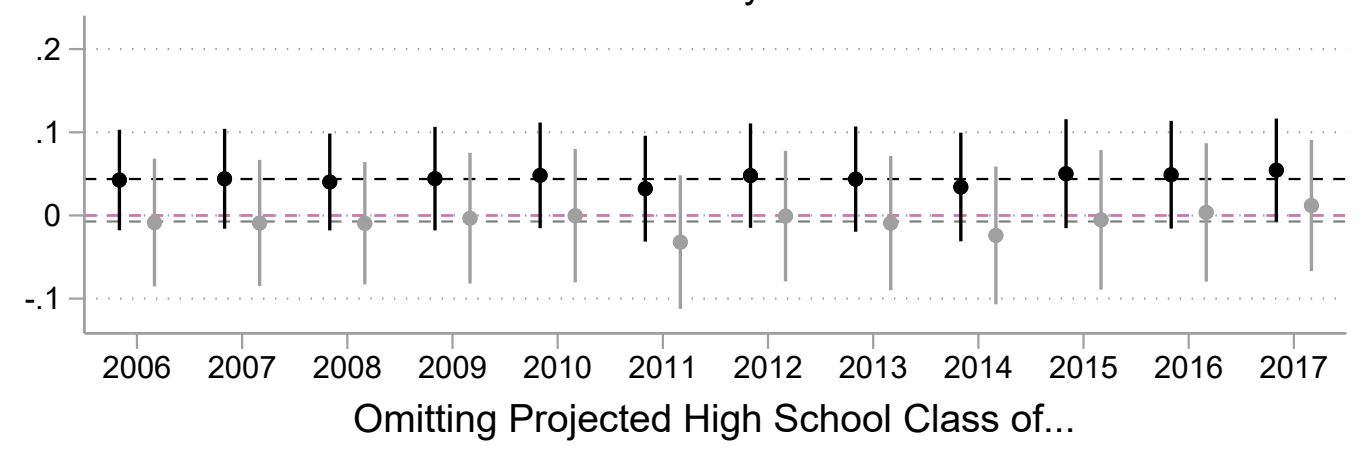

- Share Presidential - Voted in First Possible Presidential Election

Notes: This figure shows 2SLS impacts (dots) and a 95\% confidence interval (lines) for estimates of charter school attendance on voting, omitting each projected high school cohort in turn. A red dashed line indicates 0. Dashed black and grey lines indicate the impact estimates without omissions.

Online Appendix 25 
Figure D.2: Voting Impacts Omitting Schools

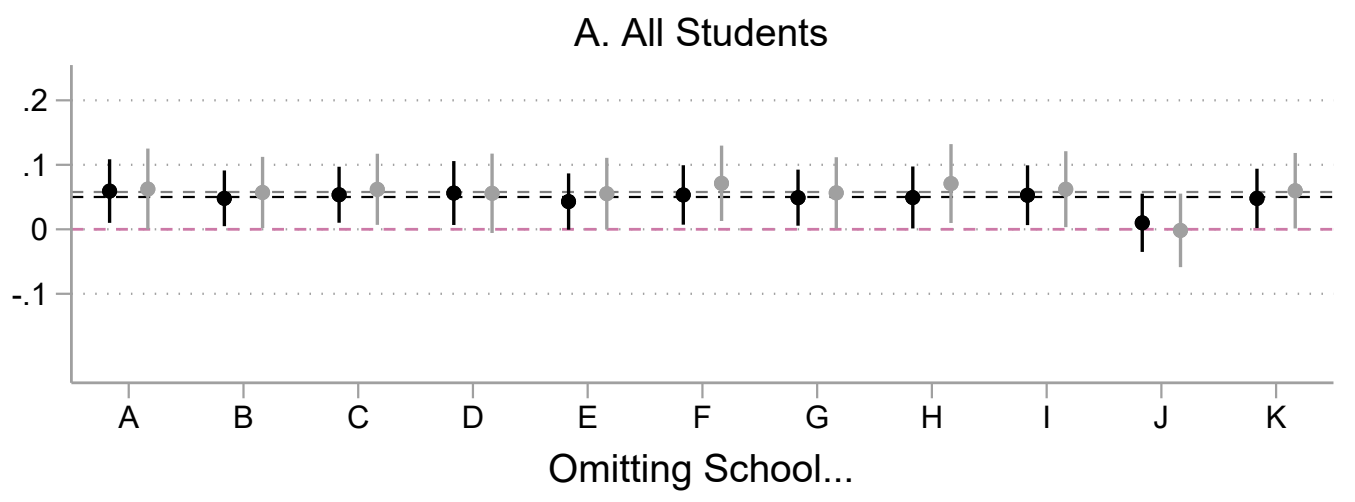

B. Girls

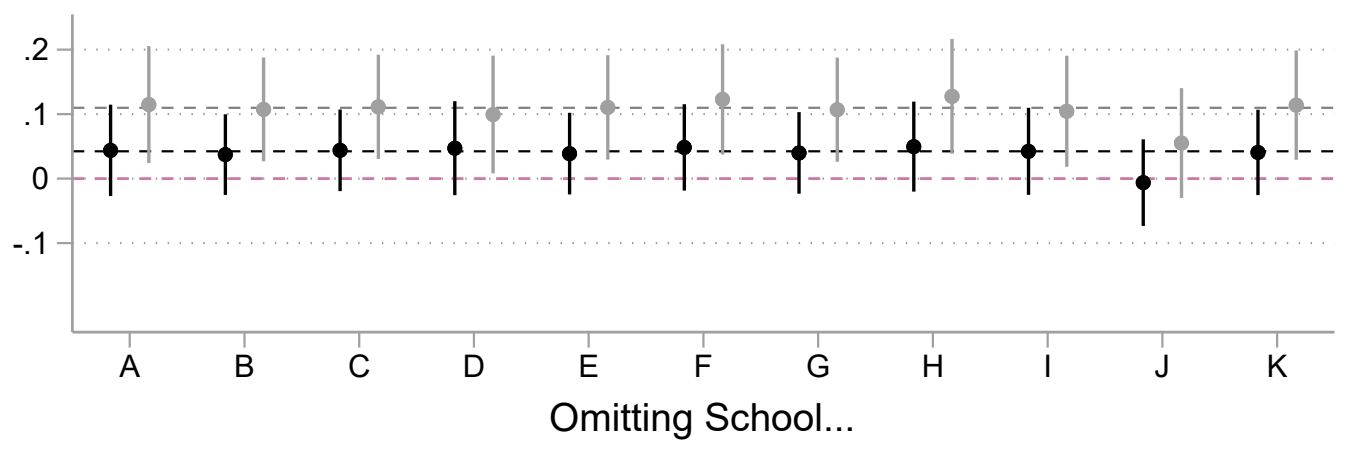

C. Boys



- Share Presidential - Voted in First Possible Presidential Election

Notes: This figure shows 2SLS impacts (dots) and a 95\% confidence interval (lines) for estimates of charter school attendance on voting, omitting each applicants to each school in the sample in turn (in random order). A red dashed line indicates 0. Dashed black and grey lines indicate the impact estimates without omissions.

Online Appendix 26 


\section{Comparisons to prior work}

Online Appendix Table D.1 goes through the exercise of progressively modifying the estimates presented here to make them more similar to the estimates in ACDPW, first omitting the additional schools and cohorts added since more time has passed, then adjusting the specification to reflect changes in modeling choices. There are two notable differences, the first for Advanced Placement (AP) and the second for college enrollment.

AP impacts are smaller here, with the largest contributing factor being the inclusion of more recent cohorts, as BPS has expanded its AP offerings over this time period, meaning that students attending counterfactual schools have more AP offerings and take up more AP options. In projected high school classes of 2012 and prior (corresponding to ACDPW), the control complier rate of AP test-taking was 24 percent; in the more recent cohorts, the control complier mean was 31 percent. There are also differences in AP outcomes due to the inclusion of Boston charter middle schools in our sample. Some Boston charter schools that serve high school grades require or strongly encourage APs, whereas students who attended a middle school charter but then went to the traditional public school system may not encounter a high school curriculum similarly focused on APs.

The magnitude of the 4-year college enrollment impact is also smaller than the estimates reported in ACDPW - 7.2 versus 18.3 percentage points. Differences are largely due to the fact that ACDPW conditions on presence in 10th grade in Massachusetts. Once we apply the same sample and modeling choices, our comparable estimate is 16.5 percentage points versus ACDPW's 18.3 percentage points. This remaining difference is due to minor variations in data processing (i.e., matching more eligible students to the SIMS, processing the college data differently, and minor updates to the databases supplied by DESE). There is no charter impact on presence in the data in 10th grade, so these estimates are still causal, but the students who contribute to the analysis are different. In short, there are some differences between our estimates and the prior literature, but as a whole, all of the estimates show substantial academic and attainment gains for charter students. 


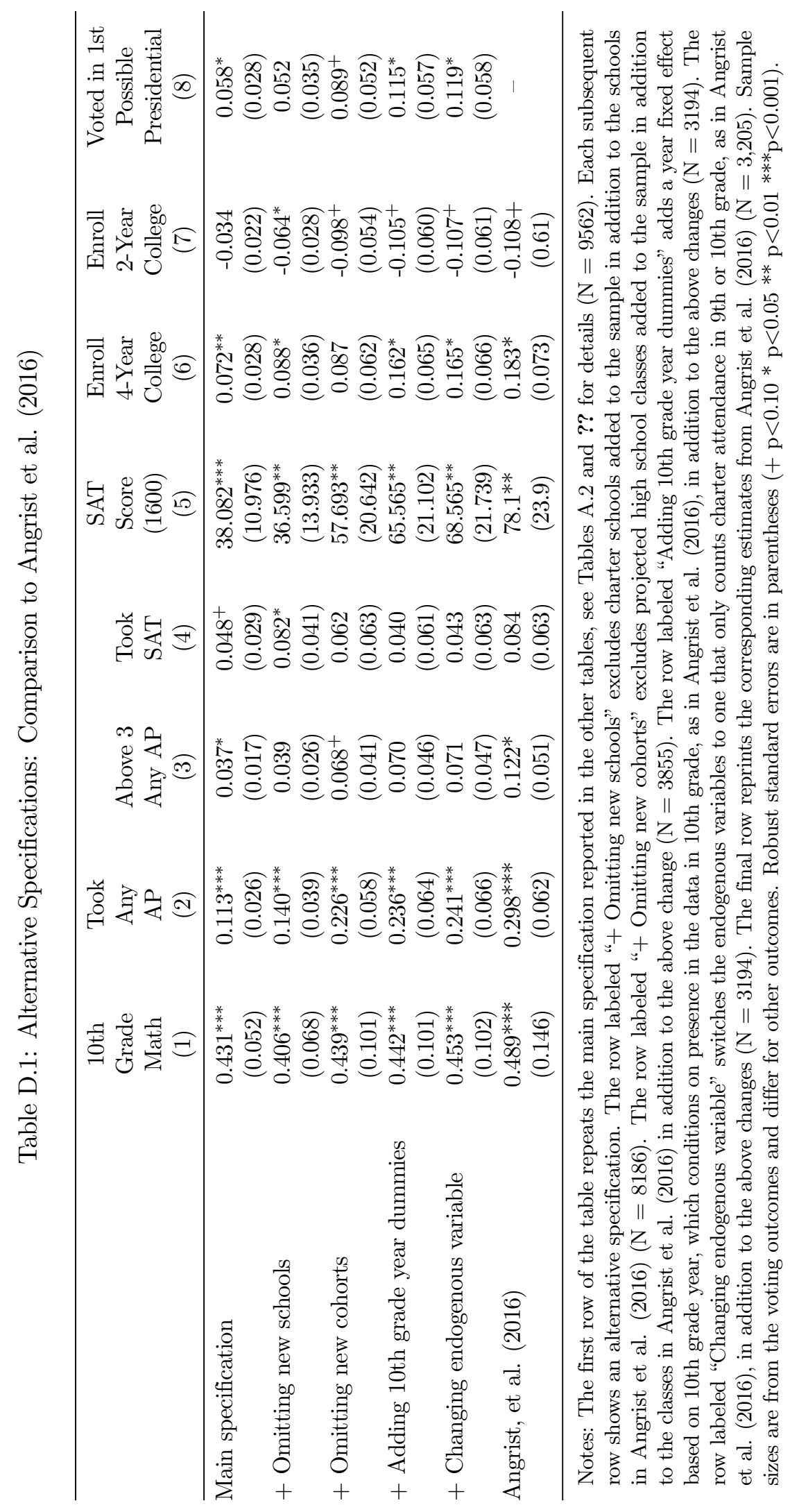

Online Appendix 28 
Other robustness checks

Online Appendix 29 


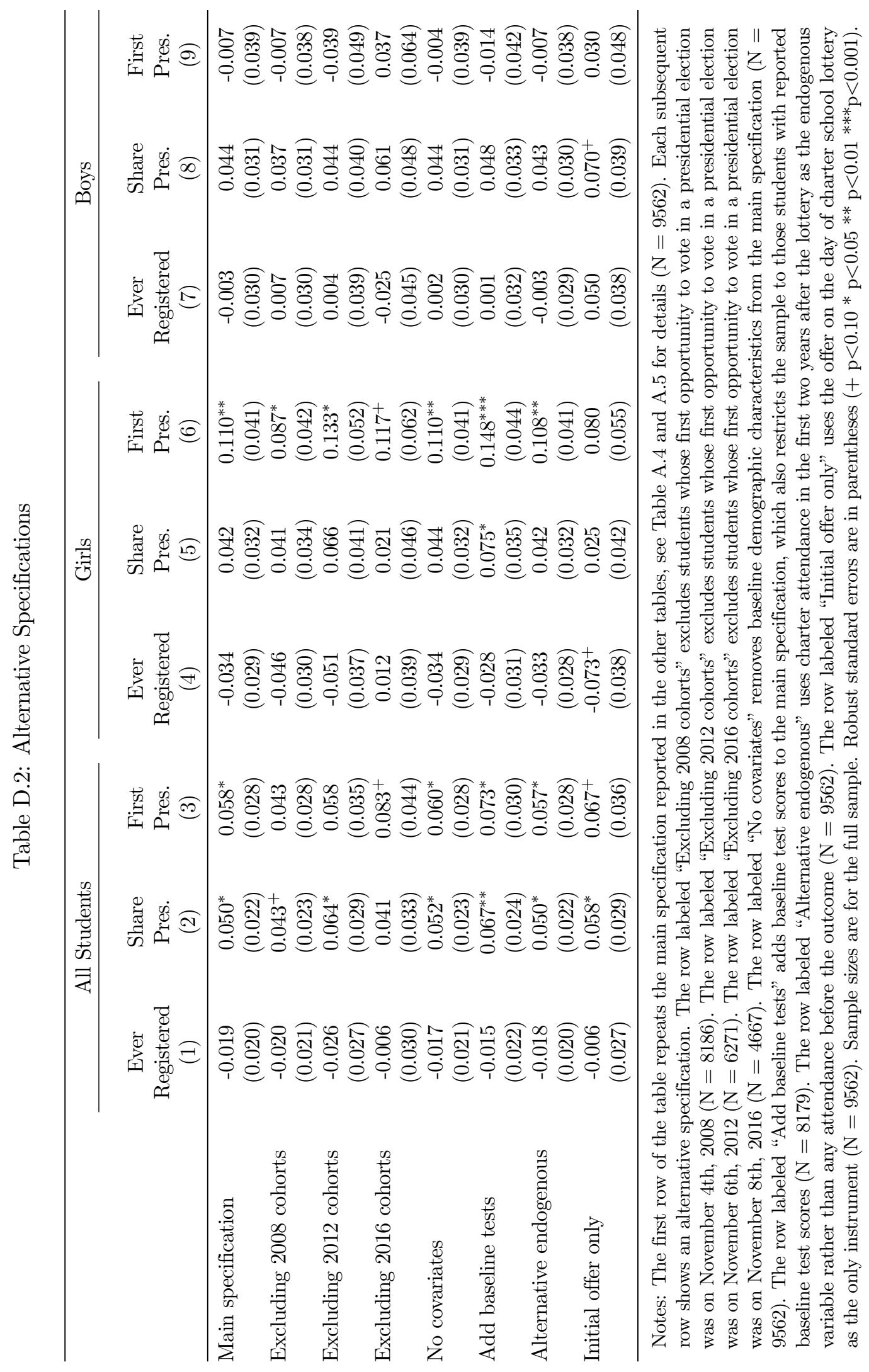

Online Appendix 30 


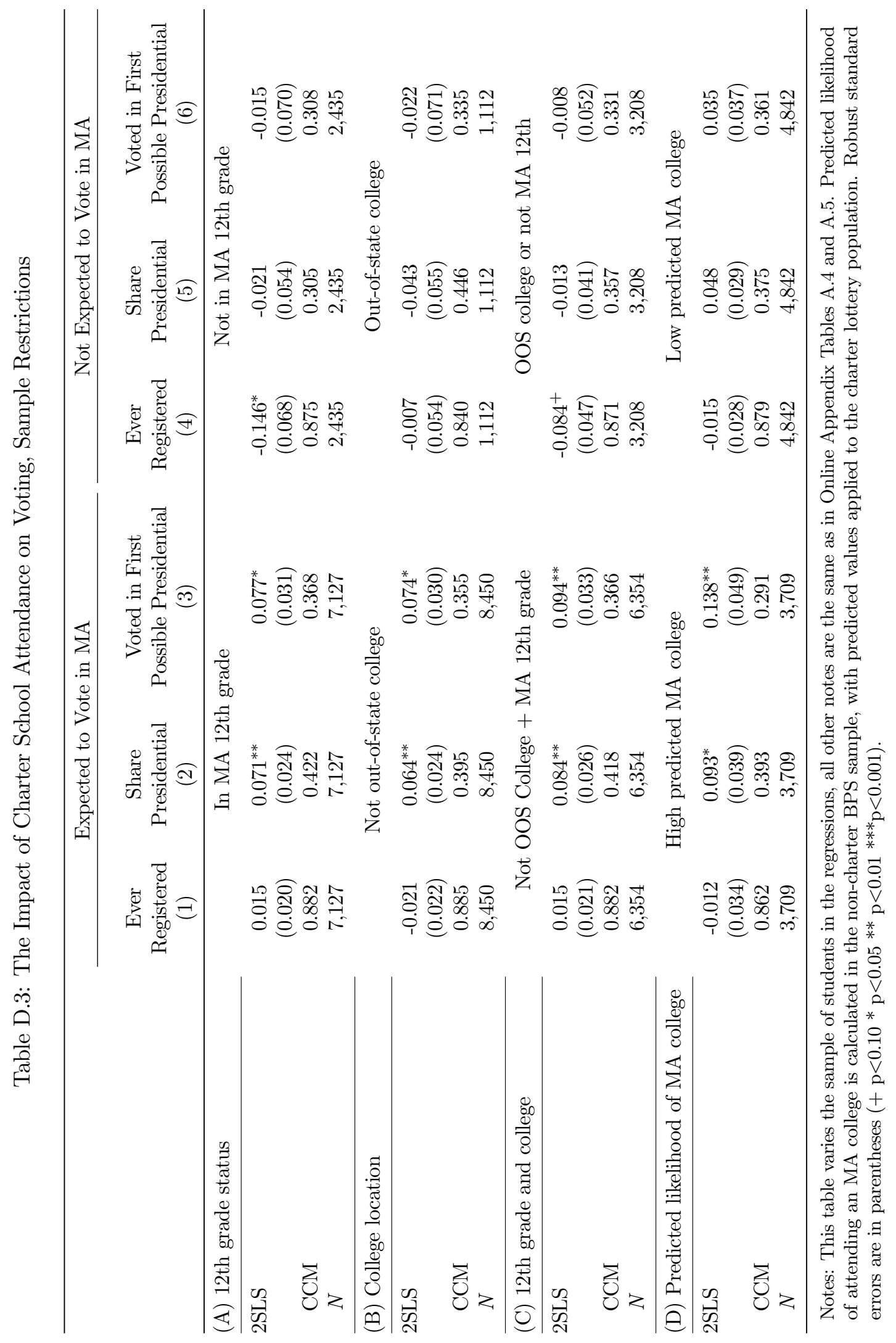

Online Appendix 31 


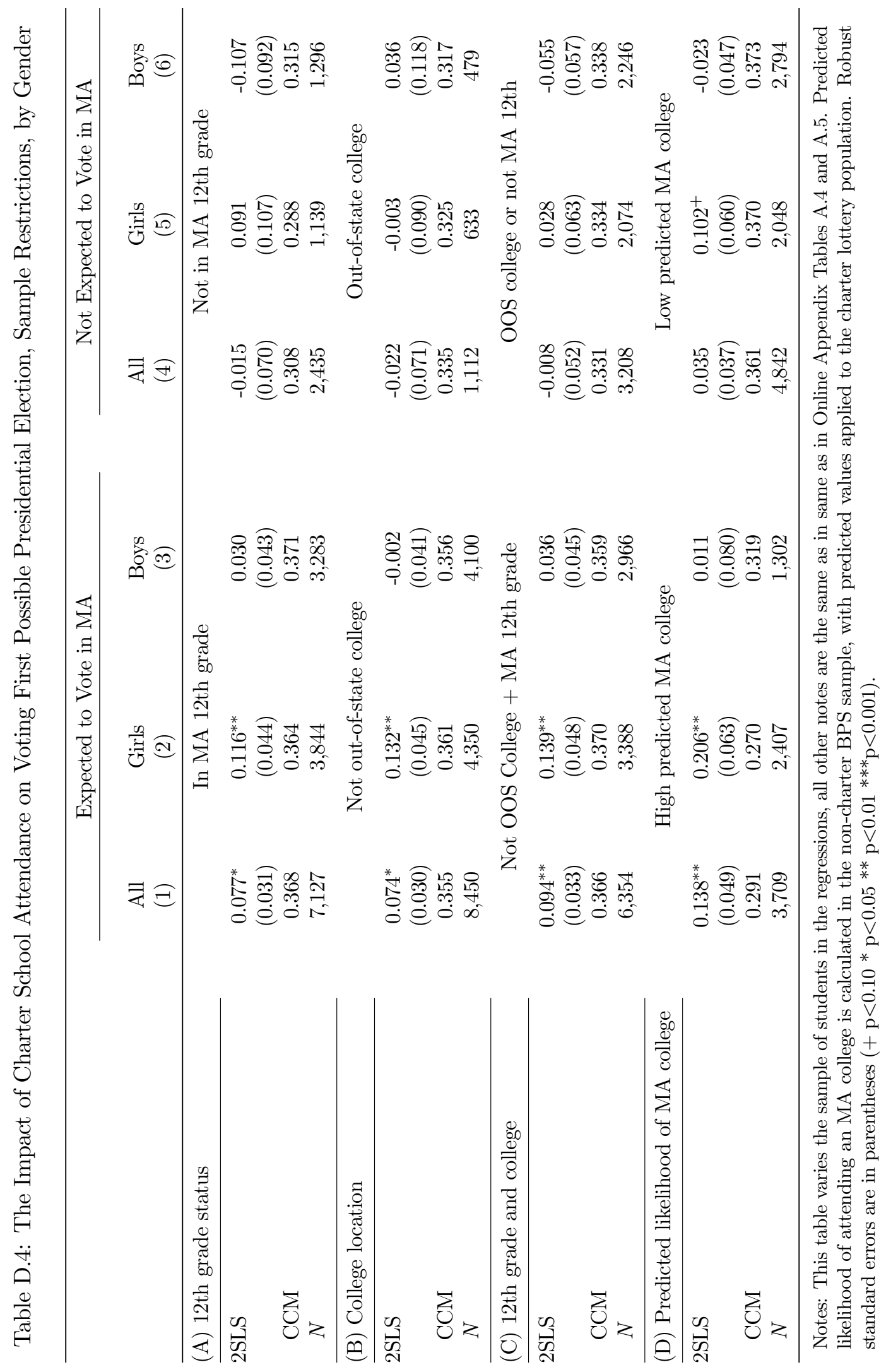

Online Appendix 32 


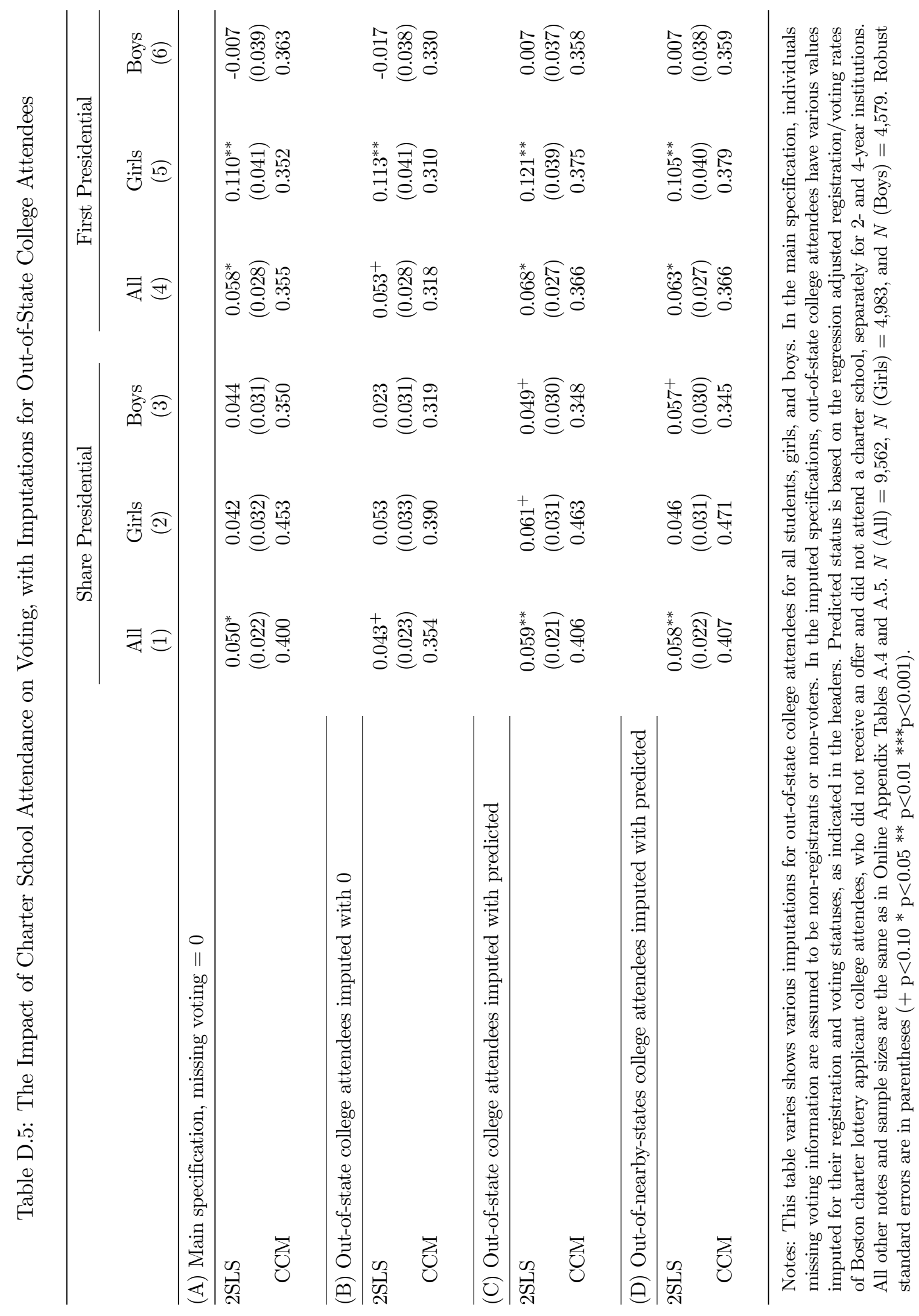

Online Appendix 33 
Appendix E: Additional Results

Online Appendix 34 
Figure E.1a: Comparisons of Lottery Effects on Voting and Education Outcomes, by Gender

A. MCAS ELA



Slope $_{\text {gril: }} 0.056(0.040)$

Slope $_{\text {boy: }}$ - 0.071 (0.062)

C. Days Attended 9th



Slope $_{\text {girl: }} 0.005(0.002)$

Slope $_{\text {boy: }} 0.001(0.002)$

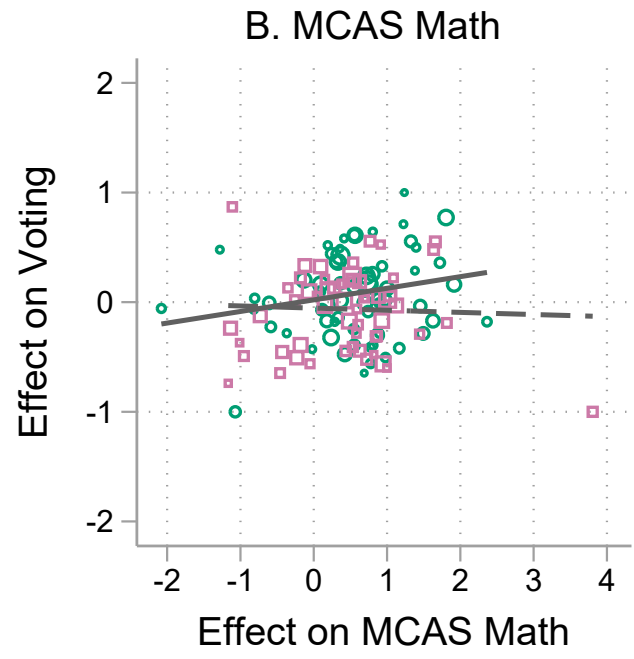

Slope $_{\text {girl: }} 0.265(0.072)$

Slope $_{\text {boy: }}$ - $0.030(0.085)$

\section{Took SAT}

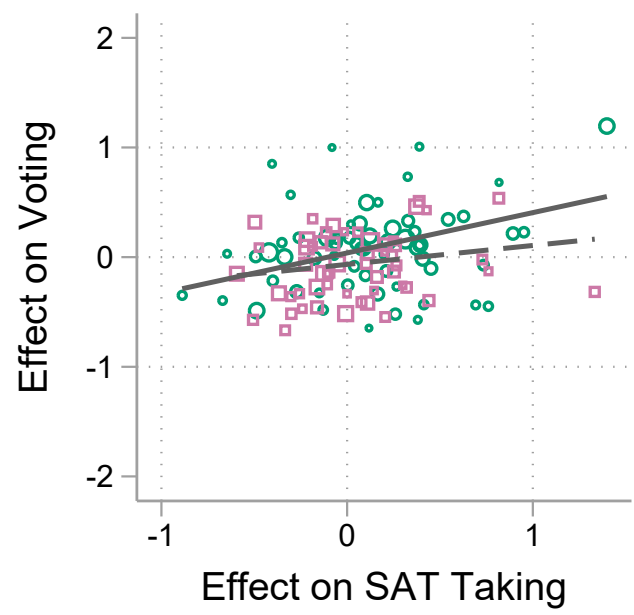

Slope $_{\text {girl: }} 0.302(0.146)$

Slope $_{\text {boy: }} 0.138(0.137)$

\section{- Girls \\ - Boys \\ - Girl linear fit \\ - - Boy linear fit}

Notes: This figure plots the effect of receiving a charter school offer on education outcomes vs. the effect on voting, for each risk set by gender. The sample includes students present in the data with both of the outcomes in the graph for the projected classes of 2006 to 2017, who were at least 18 by the 2016 general election. Marker sizes (squares for girls, circles for boys are proportional to the number of students in the risk set. Degenerate lotteries and risk sets with fewer than 15 students are excluded. A single outlier that is outside the bounds of the graph is excluded from the graph but included in the slope calculations. Lines show weighted linear fits by school level (solid for girls, dashed for boys) with weights proportional to the size of the risk set. Slope coefficients and stondard grops frøß these regressions are printed on each panel. 
Figure E.1b: Comparisons of Lottery Effects on Voting and Education Outcomes, by Gender (Continued)
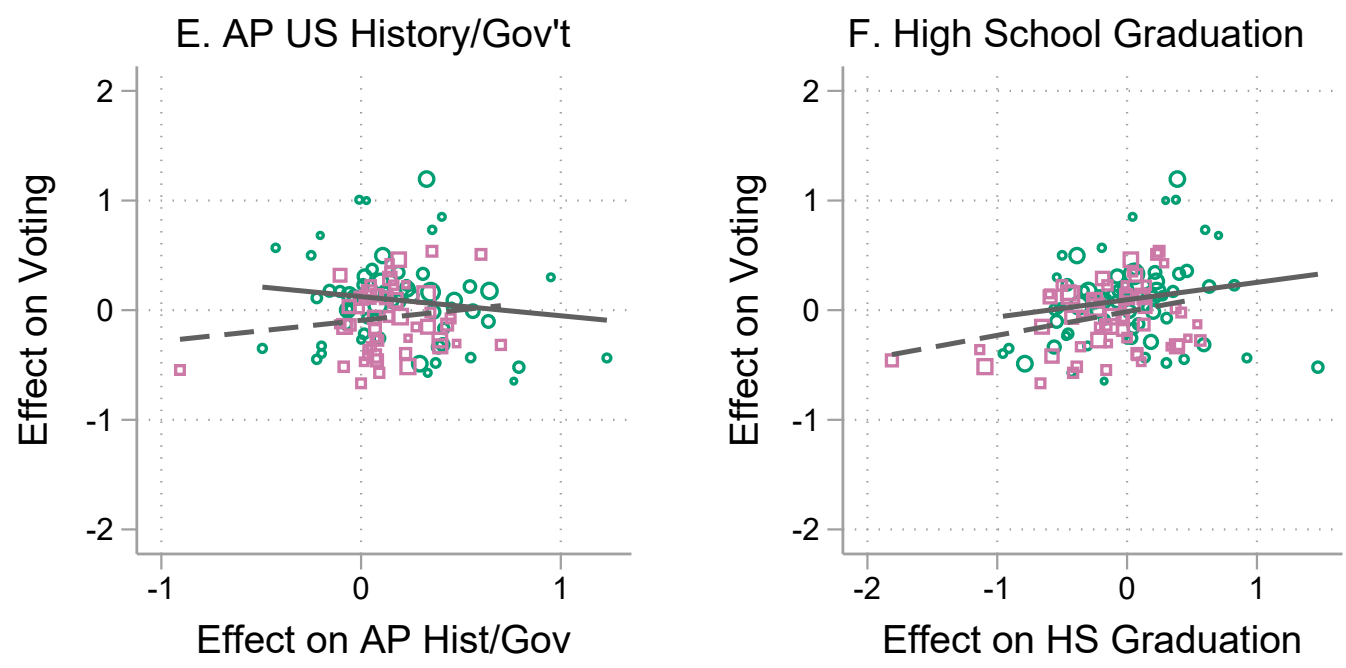

Slope $_{\text {girl }}:-0.174(0.137)$
Slope $_{\text {boy }}: 0.209(0.187)$

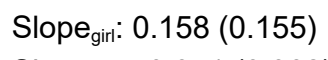

Slope $_{\text {boy }}:-0.071(0.062)$

G. 4-year College Enrollment



Slope $_{\text {girl: }} 0.310(0.145)$



- Boys

\section{- - Boy linear fit}

Notes: This figure plots the effect of receiving a charter school offer on education outcomes vs. the effect on voting, for each risk set by gender. The sample includes students present in the data with both of the outcomes in the graph, for the projected classes of 2006 to 2017, who were at least 18 by the 2016 general election. Marker sizes (squares for girls, circles for boys are proportional to the number of students in the risk set. Degenerate lotteries and risk sets with fewer than 15 students are excluded. A single outlier that is outside the bounds of the graph is excluded from the graph but included in the slope calculations. Lines show weighted linear fits by school level (solid for girls, dashed for boys) with weights proportional to the size of the risk set. Slope coefficients and stundard grops frøß these regressions are printed on each panel. 
Table E.1: The Impact of Charter School Attendance on College Enrollment by College Location

\begin{tabular}{|c|c|c|c|c|c|c|}
\hline & \multicolumn{3}{|c|}{ Within 6 months } & \multicolumn{3}{|c|}{ Within 18 months } \\
\hline & $\begin{array}{l}\text { Any } \\
(1)\end{array}$ & $\begin{array}{c}4 \text { year } \\
(2)\end{array}$ & $\begin{array}{c}2 \text { year } \\
(3)\end{array}$ & $\begin{array}{l}\text { Any } \\
(4)\end{array}$ & $\begin{array}{l}4 \text { year } \\
(5)\end{array}$ & $\begin{array}{c}2 \text { year } \\
(6)\end{array}$ \\
\hline \multicolumn{7}{|c|}{ (A) All Institutions } \\
\hline All & $\begin{array}{l}-0.005 \\
(0.028)\end{array}$ & $\begin{array}{c}0.030 \\
(0.027)\end{array}$ & $\begin{array}{c}-0.034^{*} \\
(0.016)\end{array}$ & $\begin{array}{c}0.046 \\
(0.028)\end{array}$ & $\begin{array}{c}0.072^{* *} \\
(0.028)\end{array}$ & $\begin{array}{l}-0.034 \\
(0.022)\end{array}$ \\
\hline $\mathrm{CCM}$ & 0.475 & 0.377 & 0.098 & 0.569 & 0.419 & 0.188 \\
\hline Girls & $\begin{array}{l}-0.032 \\
(0.041)\end{array}$ & $\begin{array}{c}0.000 \\
(0.040)\end{array}$ & $\begin{array}{l}-0.031 \\
(0.023)\end{array}$ & $\begin{array}{c}0.038 \\
(0.039)\end{array}$ & $\begin{array}{c}0.064 \\
(0.040)\end{array}$ & $\begin{array}{l}-0.035 \\
(0.032)\end{array}$ \\
\hline $\mathrm{CCM}$ & 0.567 & 0.469 & 0.097 & 0.639 & 0.484 & 0.202 \\
\hline Boys & $\begin{array}{c}0.015 \\
(0.039)\end{array}$ & $\begin{array}{c}0.053 \\
(0.037)\end{array}$ & $\begin{array}{l}-0.036 \\
(0.023)\end{array}$ & $\begin{array}{c}0.049 \\
(0.040)\end{array}$ & $\begin{array}{l}0.073^{+} \\
(0.039)\end{array}$ & $\begin{array}{l}-0.038 \\
(0.031)\end{array}$ \\
\hline $\mathrm{CCM}$ & 0.384 & 0.284 & 0.098 & 0.497 & 0.356 & 0.177 \\
\hline$p$-value & 0.411 & 0.338 & 0.859 & 0.852 & 0.868 & 0.948 \\
\hline \multicolumn{7}{|c|}{ (B) In Massachusetts } \\
\hline$\overline{\text { All }}$ & $\begin{array}{l}-0.026 \\
(0.028)\end{array}$ & $\begin{array}{c}0.009 \\
(0.026)\end{array}$ & $\begin{array}{l}-0.035^{*} \\
(0.016)\end{array}$ & $\begin{array}{c}0.017 \\
(0.029)\end{array}$ & $\begin{array}{c}0.036 \\
(0.028)\end{array}$ & $\begin{array}{c}-0.041^{+} \\
(0.021)\end{array}$ \\
\hline $\mathrm{CCM}$ & 0.386 & 0.292 & 0.093 & 0.482 & 0.346 & 0.185 \\
\hline Girls & $\begin{array}{l}-0.025 \\
(0.041)\end{array}$ & $\begin{array}{c}0.009 \\
(0.039)\end{array}$ & $\begin{array}{l}-0.035 \\
(0.022)\end{array}$ & $\begin{array}{c}0.023 \\
(0.041)\end{array}$ & $\begin{array}{c}0.043 \\
(0.042)\end{array}$ & $\begin{array}{l}-0.044 \\
(0.031)\end{array}$ \\
\hline $\mathrm{CCM}$ & 0.435 & 0.343 & 0.094 & 0.529 & 0.389 & 0.199 \\
\hline Boys & $\begin{array}{l}-0.030 \\
(0.038)\end{array}$ & $\begin{array}{c}0.004 \\
(0.034)\end{array}$ & $\begin{array}{l}-0.033 \\
(0.022)\end{array}$ & $\begin{array}{c}0.005 \\
(0.040)\end{array}$ & $\begin{array}{c}0.021 \\
(0.038)\end{array}$ & $\begin{array}{l}-0.042 \\
(0.030)\end{array}$ \\
\hline $\mathrm{CCM}$ & 0.338 & 0.245 & 0.092 & 0.438 & 0.309 & 0.176 \\
\hline$p$-value & 0.926 & 0.929 & 0.942 & 0.748 & 0.707 & 0.964 \\
\hline \multicolumn{7}{|c|}{ (C) Out of state } \\
\hline All & $\begin{array}{c}0.021 \\
(0.016)\end{array}$ & $\begin{array}{c}0.022 \\
(0.016)\end{array}$ & $\begin{array}{c}0.001 \\
(0.004)\end{array}$ & $\begin{array}{l}0.035^{*} \\
(0.018)\end{array}$ & $\begin{array}{l}0.036^{*} \\
(0.017)\end{array}$ & $\begin{array}{c}0.006 \\
(0.006)\end{array}$ \\
\hline CCM & 0.091 & 0.084 & 0.004 & 0.098 & 0.073 & 0.002 \\
\hline Girls & $\begin{array}{l}-0.008 \\
(0.024)\end{array}$ & $\begin{array}{l}-0.009 \\
(0.024)\end{array}$ & $\begin{array}{c}0.004 \\
(0.006)\end{array}$ & $\begin{array}{c}0.008 \\
(0.026)\end{array}$ & $\begin{array}{c}0.021 \\
(0.027)\end{array}$ & $\begin{array}{c}0.009 \\
(0.008)\end{array}$ \\
\hline $\mathrm{CCM}$ & 0.135 & 0.126 & 0.003 & 0.135 & 0.096 & 0.003 \\
\hline Boys & $\begin{array}{l}0.046^{*} \\
(0.021)\end{array}$ & $\begin{array}{l}0.048^{*} \\
(0.021)\end{array}$ & $\begin{array}{c}-0.004 \\
(0.006)\end{array}$ & $\begin{array}{l}0.061^{*} \\
(0.024)\end{array}$ & $\begin{array}{c}0.052^{*} \\
(0.023)\end{array}$ & $\begin{array}{c}0.004 \\
(0.008)\end{array}$ \\
\hline $\mathrm{CCM}$ & 0.045 & 0.040 & 0.007 & 0.058 & 0.047 & 0.001 \\
\hline$p$-value & 0.091 & 0.071 & 0.351 & 0.137 & 0.379 & 0.673 \\
\hline
\end{tabular}

Notes: The notes for this table are the same as in Table A.3 but for an expanded set of college outcomes. $N$ (All) $=9,562$, $N$ (Girls) $=4,983$, and $N$ (Boys) $=4,579$. The $p$-value from a test of equality of the girl and boy coefficients is listed in the final row of each panel. Robust standard errors are in parentheses $\left(+\mathrm{p}<0.10^{*} \mathrm{p}<0.05^{* *} \mathrm{p}<0.01{ }^{* * *} \mathrm{p}<0.001\right)$. 
Table E.2: The Impact of Charter School Attendance on Voting, by Age at First Presidential

\begin{tabular}{|c|c|c|c|}
\hline & $\begin{array}{c}\text { Ever } \\
\text { Registered } \\
(1)\end{array}$ & $\begin{array}{c}\text { Share } \\
\text { Presidential } \\
(2)\end{array}$ & $\begin{array}{c}\text { Voted in First } \\
\text { Possible Presidentia } \\
(3)\end{array}$ \\
\hline \multicolumn{4}{|c|}{ (A) Turn 18 Close to Presidential Election } \\
\hline All & $\begin{array}{c}-0.026 \\
(0.030)\end{array}$ & $\begin{array}{l}0.058^{+} \\
(0.032)\end{array}$ & $\begin{array}{l}0.075^{+} \\
(0.041)\end{array}$ \\
\hline $\mathrm{CCM}$ & 0.873 & 0.394 & 0.330 \\
\hline$N$ & 5,475 & 5,475 & 5,475 \\
\hline Girls & $\begin{array}{c}-0.024 \\
(0.041)\end{array}$ & $\begin{array}{c}0.073 \\
(0.046)\end{array}$ & $\begin{array}{c}0.186^{* *} \\
(0.060)\end{array}$ \\
\hline $\mathrm{CCM}$ & 0.879 & 0.435 & 0.275 \\
\hline$N$ & 2,883 & 2,883 & 2,883 \\
\hline Boys & $\begin{array}{c}-0.027 \\
(0.045)\end{array}$ & $\begin{array}{c}0.026 \\
(0.044)\end{array}$ & $\begin{array}{c}-0.059 \\
(0.057)\end{array}$ \\
\hline $\mathrm{CCM}$ & 0.866 & 0.358 & 0.395 \\
\hline$N$ & 2,592 & 2,592 & 2,592 \\
\hline \multicolumn{4}{|c|}{ (B) Turn 18 Farther from Presidential Election } \\
\hline All & $\begin{array}{c}0.004 \\
(0.028)\end{array}$ & $\begin{array}{l}0.056^{+} \\
(0.031)\end{array}$ & $\begin{array}{c}0.052 \\
(0.039)\end{array}$ \\
\hline $\mathrm{CCM}$ & 0.875 & 0.401 & 0.380 \\
\hline$N$ & 4,087 & 4,087 & 4,087 \\
\hline Girls & $\begin{array}{c}-0.044 \\
(0.039)\end{array}$ & $\begin{array}{c}0.010 \\
(0.046)\end{array}$ & $\begin{array}{c}0.023 \\
(0.057)\end{array}$ \\
\hline $\mathrm{CCM}$ & 0.912 & 0.481 & 0.445 \\
\hline$N$ & 2,100 & 2,100 & 2,100 \\
\hline Boys & $\begin{array}{c}0.038 \\
(0.040)\end{array}$ & $\begin{array}{l}0.077^{+} \\
(0.042)\end{array}$ & $\begin{array}{c}0.051 \\
(0.053)\end{array}$ \\
\hline $\mathrm{CCM}$ & 0.843 & 0.335 & 0.326 \\
\hline$N$ & 1,987 & 1,987 & 1,987 \\
\hline
\end{tabular}

Notes: Each coefficient labeled All, Girls, or Boys is the 2SLS instrumental variables estimate of attending a Boston charter with a lottery at any period of time before the outcome listed in the row heading occurred for the full sample, girls, or boys. Indicator variables for a lottery offer on the day of the lottery (initial offer) and lottery offer off of the waitlist (waitlist offer) are the instruments for charter attendance. The control complier mean is labeled CCM. All regressions control for lottery risk sets and a vector of demographic characteristics including indicators for race, birth year, and baseline special education, English learner, and free or reduced price lunch status, all interacted with gender. The sample is restricted to students enrolled Boston Public Schools or Boston charter schools at the time of application in the projected high school classes of 2006 to 2017 who are at least 18 by the 2016 general election. Robust standard errors are in parentheses $\left(+\mathrm{p}<0.10^{*} \mathrm{p}<0.05^{* *} \mathrm{p}<0.01{ }^{* * *} \mathrm{p}<0.001\right)$. Panel A limits the sample to students who turn 18 within two years prior to their first possible presidential vote. Panel B limits the sample to students who are not in Panel A.

Online Appendix 38 


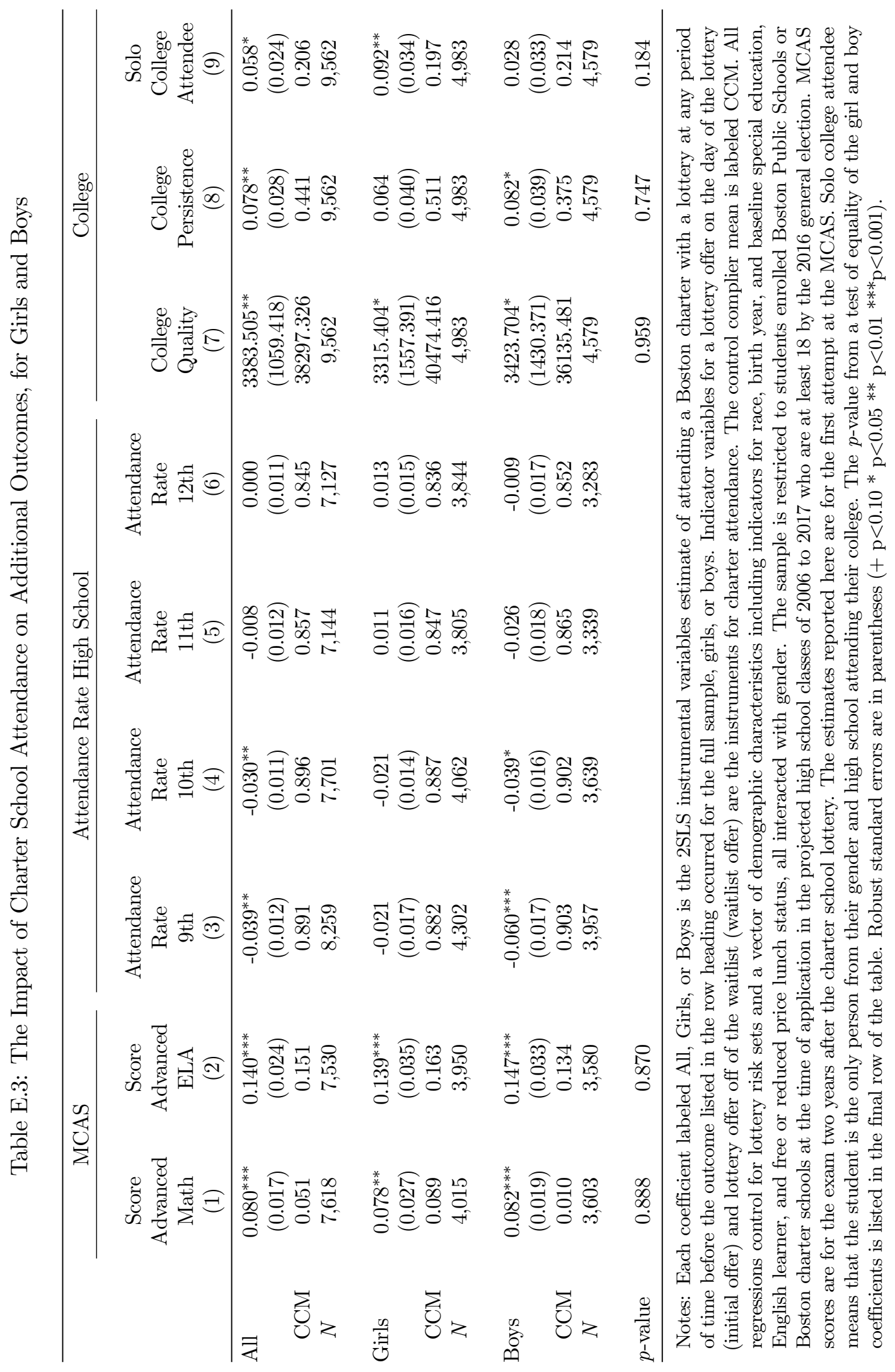

Online Appendix 39 
Appendix F: Parents

Online Appendix 40 
Table F.1: Covariate Balance, Lotteries with Parent Information, Student Characteristics

\begin{tabular}{|c|c|c|c|}
\hline & $\begin{array}{l}\text { Non-offered } \\
\text { Mean } \\
(1)\end{array}$ & $\begin{array}{c}\text { Initial Offer } \\
\text { Differential } \\
(2)\end{array}$ & $\begin{array}{c}\text { Waitlist Offer } \\
\text { Differential } \\
(3)\end{array}$ \\
\hline Female & 0.507 & $\begin{array}{c}0.001 \\
(0.014)\end{array}$ & $\begin{array}{l}-0.007 \\
(0.014)\end{array}$ \\
\hline Asian & 0.026 & $\begin{array}{c}0.007 \\
(0.004)\end{array}$ & $\begin{array}{l}-0.001 \\
(0.004)\end{array}$ \\
\hline Black & 0.513 & $\begin{array}{l}-0.002 \\
(0.013)\end{array}$ & $\begin{array}{c}0.007 \\
(0.014)\end{array}$ \\
\hline Latinx & 0.345 & $\begin{array}{l}-0.006 \\
(0.013)\end{array}$ & $\begin{array}{l}-0.005 \\
(0.013)\end{array}$ \\
\hline Other race & 0.043 & $\begin{array}{c}0.006 \\
(0.006)\end{array}$ & $\begin{array}{l}-0.003 \\
(0.005)\end{array}$ \\
\hline White & 0.073 & $\begin{array}{c}-0.004 \\
(0.006)\end{array}$ & $\begin{array}{c}0.001 \\
(0.006)\end{array}$ \\
\hline Special education & 0.211 & $\begin{array}{c}0.008 \\
(0.011)\end{array}$ & $\begin{array}{c}-0.032^{* *} \\
(0.011)\end{array}$ \\
\hline English learner & 0.194 & $\begin{array}{c}0.005 \\
(0.009)\end{array}$ & $\begin{array}{l}-0.002 \\
(0.010)\end{array}$ \\
\hline Free/reduced price lunch & 0.779 & $\begin{array}{l}-0.003 \\
(0.012)\end{array}$ & $\begin{array}{c}0.003 \\
(0.012)\end{array}$ \\
\hline Baseline MCAS ELA & -0.529 & $\begin{array}{l}-0.026 \\
(0.028)\end{array}$ & $\begin{array}{l}0.053+ \\
(0.029)\end{array}$ \\
\hline Baseline MCAS Math & -0.493 & $\begin{array}{l}-0.018 \\
(0.027)\end{array}$ & $\begin{array}{c}0.034 \\
(0.028)\end{array}$ \\
\hline & $p$-value & 0.809 & 0.398 \\
\hline
\end{tabular}

Notes: This table shows means and offer differentials for student and parent characteristics in the parent lottery sample. The sample is restricted to students enrolled Boston Public Schools or Boston charter schools who applied to charter schools in 2008 to 2016 who applied to lotteries with parent name information. Student characteristics are from the SIMS data and the data is limited to one observation per student $(n=7,760)$. Column 1 shows the proportion of non-offered students with a given characteristic. Columns 2 and 3 report coefficients from regressions of the student characteristic on initial and waitlist offer dummies, including controls for risk sets $\left(+\mathrm{p}<0.10^{*} \mathrm{p}<0.05 * * \mathrm{p}<0.01 * * * \mathrm{p}<0.001\right)$. 
Table F.2: Covariate Balance, Lotteries with Parent Information, Parent Characteristics

\begin{tabular}{|c|c|c|c|}
\hline & $\begin{array}{l}\text { Non-offered } \\
\text { Mean } \\
\text { (1) }\end{array}$ & $\begin{array}{l}\text { Initial Offer } \\
\text { Differential } \\
\quad(2)\end{array}$ & $\begin{array}{c}\text { Waitlist Offer } \\
\text { Differential } \\
(3)\end{array}$ \\
\hline \multicolumn{4}{|l|}{ (A) Has parent name } \\
\hline Parent name present in lottery records & 0.990 & $\begin{array}{l}0.006^{*} \\
(0.003)\end{array}$ & $\begin{array}{l}-0.001 \\
(0.003)\end{array}$ \\
\hline \multicolumn{4}{|l|}{ (B) Parent name characteristics } \\
\hline Length of first name & 6.066 & $\begin{array}{c}0.027 \\
(0.039)\end{array}$ & $\begin{array}{l}-0.018 \\
(0.041)\end{array}$ \\
\hline Length of last name & 6.445 & $\begin{array}{c}0.078 \\
(0.049)\end{array}$ & $\begin{array}{l}-0.012 \\
(0.051)\end{array}$ \\
\hline Commonality of name & 222.751 & $\begin{array}{c}0.777 \\
(14.038)\end{array}$ & $\begin{array}{c}-4.555 \\
(14.317)\end{array}$ \\
\hline Not common name & 0.842 & $\begin{array}{c}0.000 \\
(0.010)\end{array}$ & $\begin{array}{c}0.002 \\
(0.010)\end{array}$ \\
\hline & $p$-value & 0.427 & 0.971 \\
\hline \multicolumn{4}{|l|}{ (C) Linked to voting data } \\
\hline Linked to one voting record & 0.479 & $\begin{array}{l}-0.002 \\
(0.013)\end{array}$ & $\begin{array}{c}0.008 \\
(0.014)\end{array}$ \\
\hline Linked to multiple voting records & 0.255 & $\begin{array}{l}-0.007 \\
(0.011)\end{array}$ & $\begin{array}{l}-0.001 \\
(0.011)\end{array}$ \\
\hline Linked to no voting records & 0.256 & $\begin{array}{c}0.015 \\
(0.012)\end{array}$ & $\begin{array}{l}-0.008 \\
(0.012)\end{array}$ \\
\hline
\end{tabular}

Notes: This table shows means and offer differentials for student and parent characteristics. The sample is restricted to students enrolled Boston Public Schools or Boston charter schools who applied to charter schools in 2008 to 2016 who applied to lotteries with parent name information. Parent name characteristics (Panel B) are derived from parent names and thus are conditional on existence of a parent name. There are multiple observations per student if a student has two parent names associated with their information (Panel A: $\mathrm{N}=11,007$, Panels B and C: $\mathrm{N}=10,865$ ); in this case, standard errors are clustered by student. Column 1 shows the proportion of non-offered students with a given characteristic. Columns 2 and 3 report coefficients from regressions of the student characteristic on initial and waitlist offer dummies, including controls for risk sets $\left(+\mathrm{p}<0.10^{*} \mathrm{p}<0.05^{* *} \mathrm{p}<0.01 * * * \mathrm{p}<0.001\right)$. 